University of Rhode Island

DigitalCommons@URI

Open Access Master's Theses

1985

\title{
An Interactive Computer Model for Oil Spill Training
}

Kurt A. Hansen

University of Rhode Island

Follow this and additional works at: https://digitalcommons.uri.edu/theses

\section{Recommended Citation}

Hansen, Kurt A., "An Interactive Computer Model for Oil Spill Training" (1985). Open Access Master's Theses. Paper 599.

https://digitalcommons.uri.edu/theses/599

This Thesis is brought to you for free and open access by DigitalCommons@URI. It has been accepted for inclusion in Open Access Master's Theses by an authorized administrator of DigitalCommons@URI. For more information, please contact digitalcommons-group@uri.edu. 
AN INTERACTIVE COMPUTER MODEL

FOR OIL SPILL TRAINING

BY

KURT A. HANSEN

A THESIS SUBMITTED IN PARTIAL FULFILLMENT OF THE REQUIREMENTS FOR THE DEGREE OF

MASTER OF SCIENCE

IN

OCEAN ENGINEERING

UNIVERSITY OF RHODE ISLAND

1985 


\section{MASTER OF SCIENCE THESIS}

OF

KURT A. HANSEN

\section{APPROVED.}

Thes is Committee

Major Professor

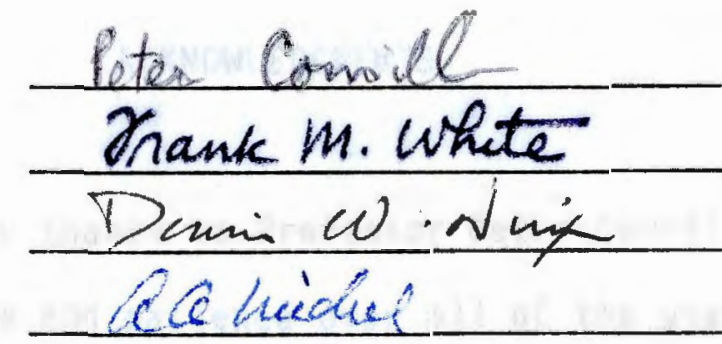

DEAN OF GRADUATE SCHOOL

UNIVERSITY OF RHODE ISI.AND

1985 


\section{ABSTRACT}

An interactive computer model which can be used for marine oil prediction research and as a training tool has been developed. It uses an existing model from the University of Rhode Island which permits tracking of surface as well as entrained subsurface oil. To this are added models of spill cleanup and containment as well as calculations of costs involved for each of the response techniques. The performance of a response is judged in terms of the environmental and aesthetic impact-of ofl on an area. The model is set up and run for two actual spills in Narragansett Bay as well as several example spills in the Rhode Island area. Outside evaluators have reviewed the model and judged it useful for training and prediction.

\section{ACKNOWLEDGMENTS}

I wish to express my thanks to Professor Peter Cornillon, my major advisor. for his guidance and patience over all of the years of our association.

I am appreciative of all of the help that my fellow graduate students in Ocean Engineering have given me throughout the years. They 
are too numerous to list the names and all of the assistance they supplied, but for their suggestions and contributions of data I am immeasurably thankful.

I would like to thank the URI Academic Computer Center staff who have come to know me so well. They have consistently supplied me with support through all of the software and hardware changes, especially Mr. Roger Greenwall.

Special thanks are extended to my friends, coworkers and relatives who have supported me throughout and have shown great patience. For those who haven't heard from me in the past few years, would someone please let them know that I am alive.

My warmest and strongest expression of thanks is reserved for my wife, Beth. The work on this thes is has extended longer than our marriage and one and one-half degrees and several jobs for her. Without her patience, understanding, companionship and love, this feat would not have been accomplished. Her undying confidence supplied me with an unshakable backup which pulled me through the trouble spots of this research. I will be forever thankful and hope that I can someday repay all of the support and patience which she expended. 


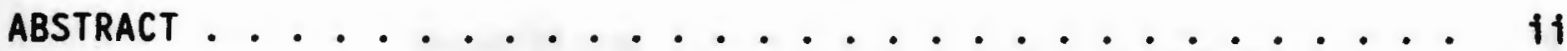

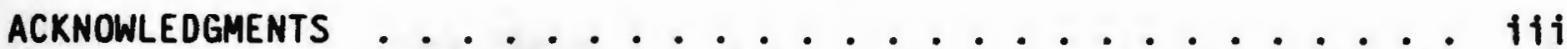

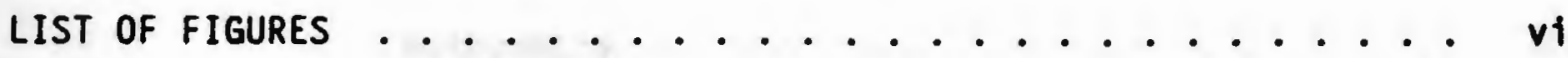
LIST OF TABLES ....................... ix

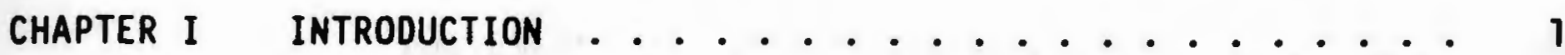
011 Spill Processes............... . . 1 Responses................ 10 Training .................... 14 A Training Alternative ........... 16

CHAPTER II COMPUTER MODELING ............... 17 Modeling Selection ................ 17 Modeling Responses ............ 25

CHAPTER III MODEL DEVELOPMENT ................. 30 URI Mode1................... 30

Shoreline Processes............ 32

Mode led Responses............... 35

Containment ................. 38

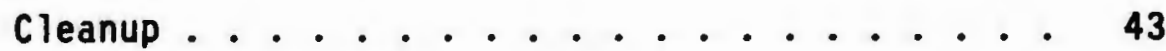

Cleanup on Shore ............ 48

Dispersants............. 52

Spill Impact and Costs ............. 56

Model Integration ............... 62 
CHAPTER IV VALIDATION AND APPLICATION ...........

Simulation Setup........................ 78

wind ...................... 78

Currents................. 79

Temperature .............. 81

Sea State ............. 81

Bathymetry .............. 83

Coastiline .............. 83

Equipment ............. 86

Process Validation............. 86

Quonset Point Spill .......... 87

Pennant Spill .................. 94

Training Application............. 102

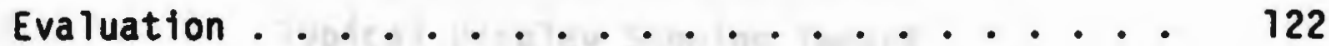

CHAPTER $V$ CONCLUSIONS .................................. 124

APPENDICES A Shoreline Interaction Routine ......... 127

B Boom Modeling ................ 132

C Block Is land Sound Runs ............ 139

D Evaluators Comments ............ 148

BIBLIOGRAPHY .......................... 151 


\begin{tabular}{|c|c|c|}
\hline Figure & $1-1$ & $0\{1$ Spill Processes \\
\hline Figure & $1-2$ & Importance of Processes Over Time \\
\hline Figure & $1-3$ & Spreading Mode 1 \\
\hline Figure & $1-4$ & Nearshore Current System \\
\hline Figure & $1-5$ & Beach Cross Section \\
\hline Figure & $1-6$ & Cleanup Organization Chart \\
\hline Figure & $1-7$ & 011 Spill Control Course Agenda \\
\hline Figure & $3-1$ & Cleanup Efficiencies \\
\hline Figure & $3-2$ & Sample of Interactive Map \\
\hline Figure & $3-3$ & Typical Display Concerning Responses \\
\hline Figure & $3-4$ & Typical Display Showing Costs \\
\hline Figure & $3-5$ & Typical Display Showing Impact \\
\hline Figure & $3-6$ & Plot of Grid System \\
\hline Figure & $3-7$ & Plot of Wind Data \\
\hline Figure & $3-8$ & Plot of Current Data \\
\hline Figure & $3-9$ & Plot of 011 Locations \\
\hline Figure & $3-10$ & Plot of Mass Distribution \\
\hline Figure & $3-11$ & Plot of Areal Coverage \\
\hline Figure & $3-12$ & Plot of Impact \\
\hline Figure & $3-13$ & $\begin{array}{l}\text { Examples of Impact Plots } \\
\text { Using Oifferent Criteria }\end{array}$ \\
\hline
\end{tabular}




\begin{tabular}{|c|c|c|}
\hline Figure & $4-1$ & Narragansett Bay Grid \\
\hline Figure & $4-2$ & Block Is land/Rhode Is land Sound Grid \\
\hline Figure & $4-3$ & Oil Locations for Quonset Point Simulation \\
\hline Figure & $4-4$ & Quonset Point Simulation Mass Oistribution \\
\hline Figure & $4-5$ & Quonset Point Simulation Impact \\
\hline Figure & $4-6$ & 011 Locations for Pennant Simulation \\
\hline Figure & $4-7$ & Pennant Simulation Mass Distribution \\
\hline Figure & $4-8$ & Pennant Simulation Impact \\
\hline Figure & $4-9$ & Narragansett Bay Application Actual Winds \\
\hline Figure & $4-10$ & 011 Locations for Narragansett Bay Applications \\
\hline Figure & $4-11$ & Narragansett Bay Application Mass Distribution \\
\hline Figure & $4-12$ & Narragansett Bay Application Impact \\
\hline Figure & $4-13$ & 011 Location During Response 1 \\
\hline Figure & $4-14$ & 011 Location During Response 2 \\
\hline Figure & $4-15$ & Mass Balance for Response 1 \\
\hline Figure & $4-16$ & Impact Plot for Response 1 \\
\hline Figure & $4-17$ & Mass Balance for Response 2 \\
\hline Figure & $4-18$ & Impact Plot for Response 2 \\
\hline
\end{tabular}

Figure Shoreline Interaction flow Chart

Figure A-2 Shoreline Interaction Example

Figure $B-1 \quad 011 / B a r r i e r$ Cross Section

Figure B-2 Boom Definition Drawing 
Figure B-3

Figure B-4

Figure B-5

Figure $\quad C-1$

Figure $\quad \mathrm{C}-2$

Figure $\quad c-3$

Figure $\quad$ C-4

Figure $\quad$ C-5

Figure $\quad c-6$

Figure $\quad c-7$
Relationship Between $X$ and Boom Length

Loss Rate (Abraham 1977)

Boom Subroutine flow Chart

Block Is land Sound Study Area

Charlestown Wind for Simulation

011 Locations for Block Is land

Sound Simulation

Mass Distribution for Block Is land

Sound Simulation

Impact for Block Is land Sound

Simulation

Mass Distribution for Dispersant Response

Impact for Dispersant Response

villi 


\begin{tabular}{|c|c|c|}
\hline Table & $2-1$ & 011 Spill Model Types \\
\hline Table & $2-2$ & 011 Spill Simulation Models Reviewed \\
\hline Table & $2-3$ & Modeling Technology of Advection \\
\hline Table & $2-4$ & $\begin{array}{l}\text { Modeling Technology of Physical/Chemical/ } \\
\text { Biological Process }\end{array}$ \\
\hline Table & $2-5$ & Sample of Simulation (Cochran et al. 1975) \\
\hline Table & $2-6$ & Sample of Calculations (Holmes 1977) \\
\hline Table & $3-1$ & $\begin{array}{l}\text { Shoreline Classification System } \\
\text { (Gundlach and Hayes 1978) }\end{array}$ \\
\hline Table & $3-2$ & Common Characteristics of Equipment \\
\hline Table & $3-3$ & Boom Characteristics \\
\hline Table & $3-4$ & Vessel Characteristics \\
\hline Table & $3-5$ & Absorbent Characteristics \\
\hline Table & $3-6$ & Wringer Characteristics \\
\hline Table & $3-7$ & Skimmer Characteristics \\
\hline Table & $3-8$ & Barge Characteristics \\
\hline Table & $3-9$ & Heavy Construction Equipment \\
\hline Table & $3-10$ & Dispersant Operation Properties \\
\hline Table & $3-11$ & Atrcraft Characteristics \\
\hline Table & $3-12$ & $\begin{array}{l}\text { Acute Toxicity of Petroleum to Marine } \\
\text { Animals (Malins 1977) }\end{array}$ \\
\hline Table & $3-13$ & 011 Spill Costs (1984 Dollars) \\
\hline
\end{tabular}




\begin{tabular}{|c|c|c|}
\hline Table & $4-1$ & Average Monthly Water Temperature \\
\hline Table & $4-2$ & Sea State Wave Heights \\
\hline Table & $4-3$ & Assigned Sea State Values \\
\hline Table & $4-4$ & Narragansett Bay Application Wind \\
\hline & & Prediction \\
\hline
\end{tabular}




\section{CHAPTER I}

\section{INTROOUCTION}

$0 i 1$ spills on water have been a major problem since the 1960's when demand for oil began to increase. In the early years between 1956 and 1970, 80 percent of the 38 spills in the world on water greater than 2,000 barrels $(24,000$ gallons) were within 10 miles of shore (Sittig 1974). Although oil spills have not been in the headlines recently, an average of over 10,500 spills each year in the United States were recorded between 1974 and 1983, with an average yearly volume of $15,656,700$ gallons spilled on water. In 1980 and 1981, 92 percent of the accidents were within three miles of the shoreline (U.S. Coast Guard 1982). The total cost of the responses to these spilis was over $\$ 300$ million, including $\$ 2.5$ million for the Argo Merchant alone (Schiff 1980). The environmental and economic impact of these spills, has lead to extensive research, designed to stop or reduce the affect that the oil has on the environment. The first step taken has been to determine the behavior of oil in a marine environment and to use this information for planning and training.

\section{0il Spill Processes}

The chemical and physical processes which affect spilled oil are complex and interrelated and both are dependent upon oil composition and 
environmental parameters. Among the competing processes, shown in Figure $1-1$, is the oil's interaction with the shoreline. Most of these are poorly understood. It is difficult, if not impossible, to take water and oil samples during an actual spill, especially if high sea states exist, so that the bulk of oil spill research has occurred in simulated laboratory environments.

Researchers have identified those factors which seem to be the most important. These include spreading, advection (both surface and subsurface), evaporation, dissolution, dispersion, emulsification, sedimentation, biodegradation, photo-oxidation and shoreline stranding. These various processes work at different rates and thus are important during different times of a spill (see Figure 1-2). They also affect one another. For example, if evaporation is high there will be less oil available for the remaining processes. The major processes are discussed be low.

Spreading is one of the most important processes in the first $6-10$ hours of the spill. Both gravitational and surface tension forces increase the spreading while friction and inertia forces tend to retard it. $0 i 1$ properties, temperature and the oil's thickness on the surface influence the forces. Short-time and small scale fluctuations also affect the rate of spreading (Stolzenbach 1977). Figure 1-3 shows the impact of spreading on an area. 


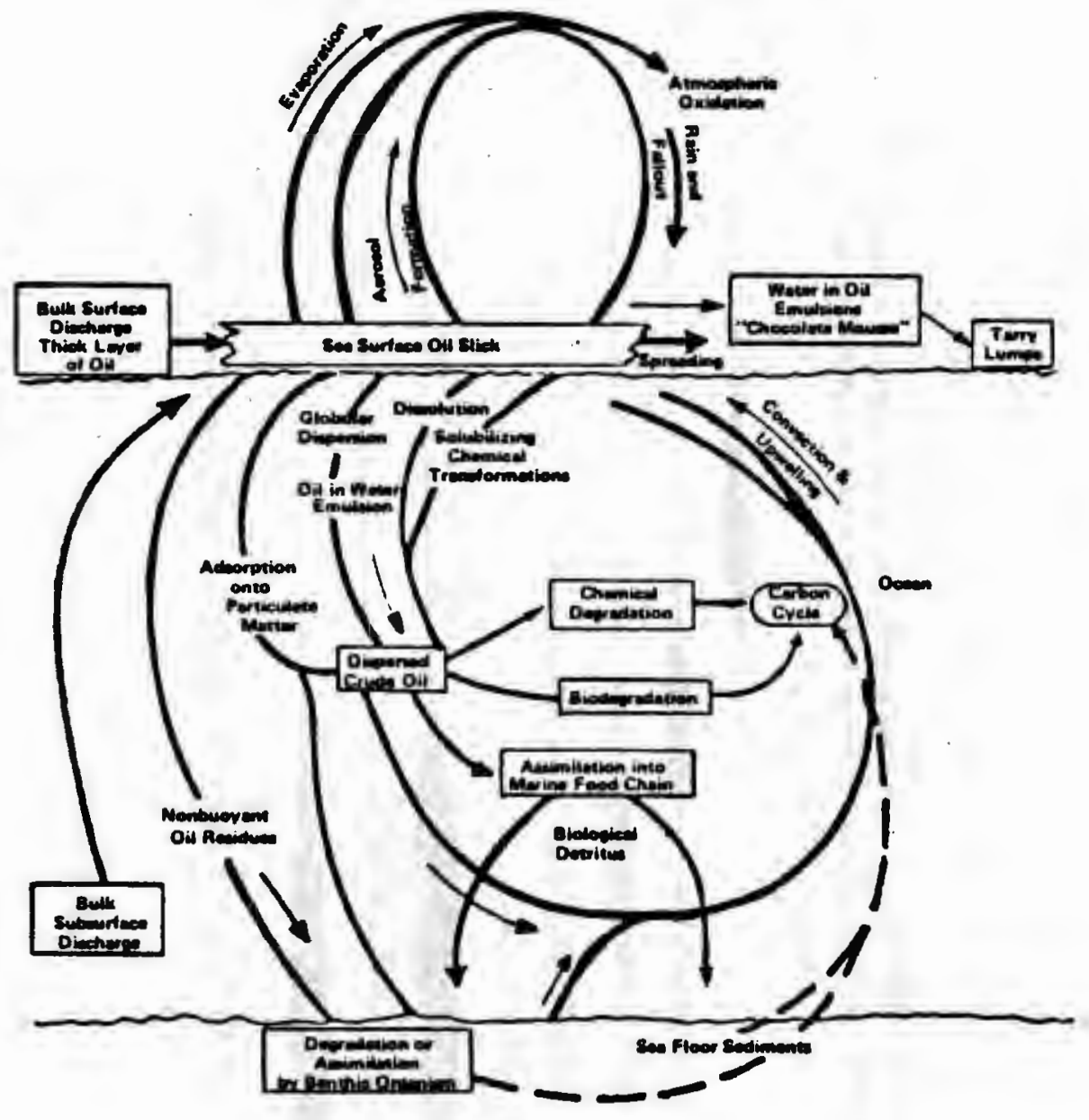

A schematic overview of the various combined and competing weathering processes that act on spilled oil in the marine environment (from Burwood and Speers, 36). Reprinted with permission from Estuarine and Coastal Marine Science, Vol. 2. 1974 by Academic Press, Inc.

\section{Figure l-1 oil Spill Processes}




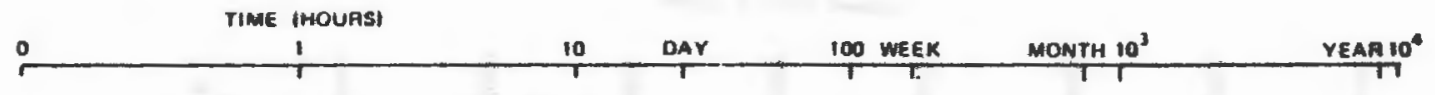
SPHEADINC:

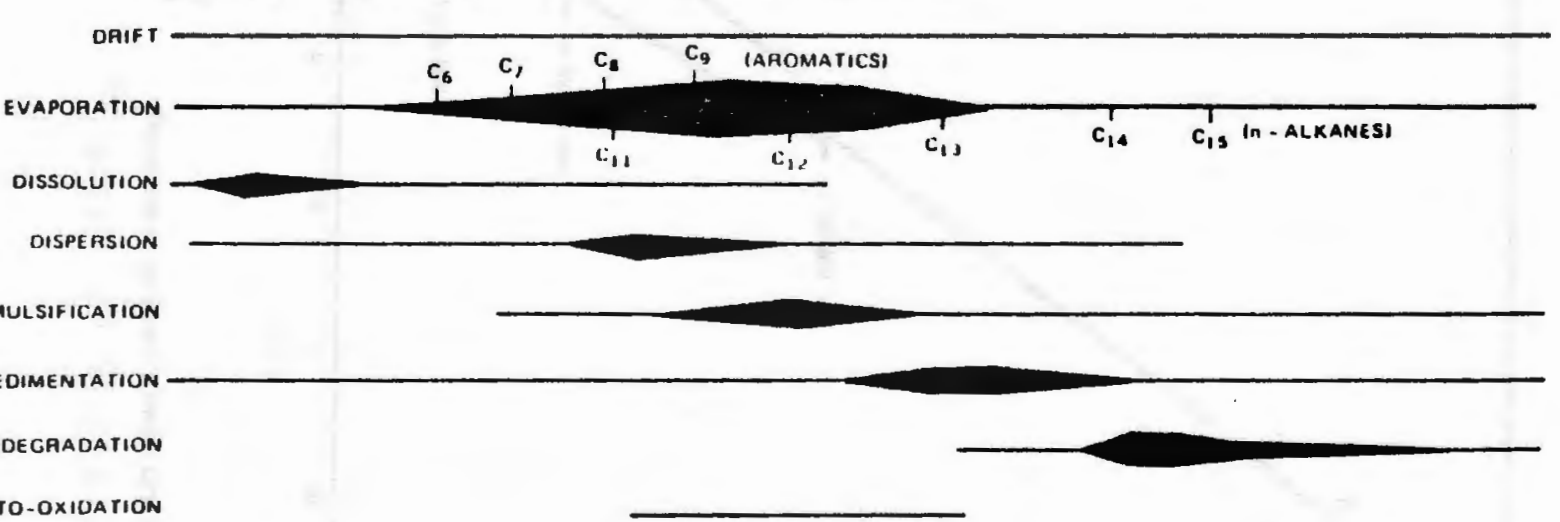

Processes versus time elapsed since the spill. The line length indicates the probable timespan of anv process. The line width indicates the relative magnitude of the process through time and in relation to other conteinporary processes.

Figure 1-2 Importance of Processes Over Time 


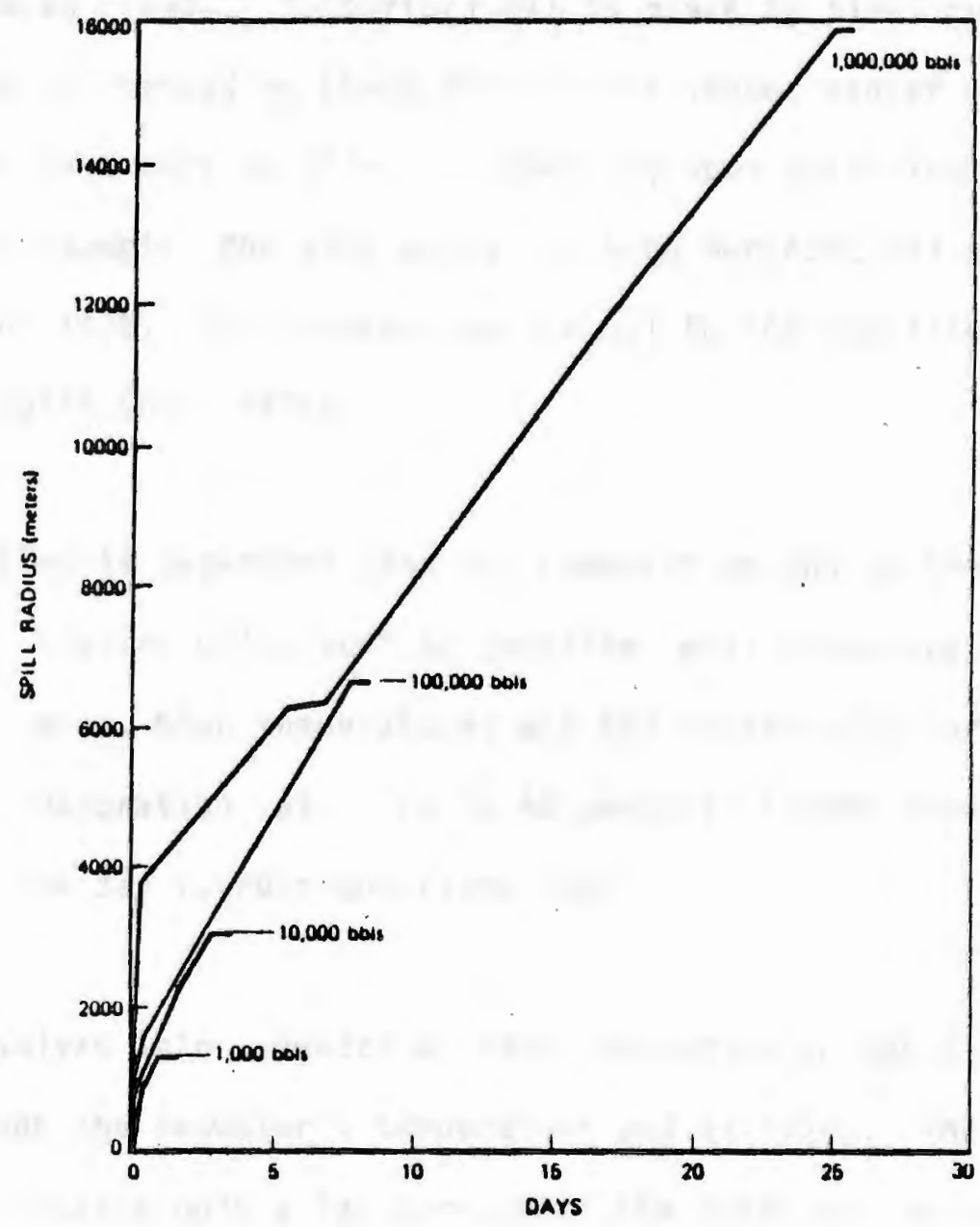

Maximum oil spill redius versus time (Fay-Hoult modell.

Figure 1-3 Spreading Model 
Advection is the movement of oil by wind, currents and waves. Surface oil movement is mostly a function of wind drift, especially for offshore areas. In some nearshore areas, tidal currents and waves become more important. Limited research has been done on the movement of ofl by waves and the resulting calculations are not easily performed for complicated wave fields. Subsurface oil is moved by tidal currents in estuaries and influenced by Ekman drift in offshore, deeper waters. Advection can have varying effects, depending upon spill location and weather. For example, the wind moved the Argo Merchant oil offshore (Argo Merchant 1978), but transported the oil to the coastline during the Amaco Cadiz spill (Hess 1978).

Evaporation is dependent upon ofl composition and on the environment. Lighter oils, such as gasoline, will evaporate faster than a crude oil. Wind, high temperatures and sea states will further increase the evaporation rate. Up to 40 percent of some crudes can evaporate in one day (Jordan and Payne 1980).

011 dissolves into seawater at rates depending on the ofl's composition and the seawater's temperature and salinity. The amount dissolved is usually only a few percent of the total volume so that dissolution is not considered to have an impact as large as most of the other processes (Davidson and Lawrence 1982). Since dissolved oils are not easily detected, more research is needed to determine how much oil is actually dissolved. 
Droplets of oil moving into the water column is called dispersion. Dispersion is larger for heavier oils and higher sea states, although little data is currently available to confirm this. Some of the droplets resurface, but most seem to be neutrally buoyant and remain in suspension. The amount of $0 i 1$ dispersed decreases as the $0 i 1$ weathers, but the particles which have been previously created continue to disperse and/or breakdown.

The water-in-oil emulsion often formed during a spill has a viscous, "chocolate-mousse" consistency, which is created by the combination of weathered oil and water. The longer the spill is exposed to the environment, the greater the percentage of oil going into emulsion. Heavier oils and colder temperatures tend to accelerate formation of emulsions. Clean-up of emulsions is a major problem due to the increased volume. Typical oil-in-water emulsions contain up to 80 percent water hence the volume of a spill may be multiplied by a factor of five in the emulsion. The bulk of the oil which stranded on the shore during the Amaco Cadiz spill was in the form of an emulsion.

Sedimentation is the process where particles of sand are mixed into the water and become attached to the oil. Since oil is very close to being neutrally buoyant, only a small amount of sediment will cause the oil to sink. This process occurs nearshore and is dependent upon depth, type of bottom, oil properties and the amount of turbulence caused by currents or waves. Once on the bottom, movement of this oily sand is dependent upon bottom currents. 
Biodegradation is the transformation of oil by microorganisms. Only certain type of organisms are included in this process and anything that effects the population such as amount of light, nutrients and temperatures, will influence the rate at which organisms consume the oil. The impact of biodegradation is important only in the long term due to the relatively slow rate at which it operates. No field work has been done to study this phenomena, only controlled studies in laboratories.

Weathering of the oil by sunlight in the presence of oxygen is called photo-oxidation. It is dependent on the amount of light, oil composition and oil thickness. It has a very low rate and is usually ignored, except in special cases.

The behavior of oil near the shore is complicated and involves many oceanographic processes. The currents in the nearshore region are both complex and dynamic depending upon the region's physical oceanography and the manner in which waves diffract and break (see figure 1-4). Beach slope, local bathymetry and winds also influence water movement. In addition, there is a great deal of turbulence present due to breaking waves which can affect how any oil present is transported or deposited. Stranding of ofl on the shoreline is also greatly influenced by the tidal range. $0 i 1$ left ashore during the transition from high to low tide, (Figure 1-5) may be refloated again during the next high tide. This was a recurring problem during the Amoco Cadiz spill (Hess 1978). 


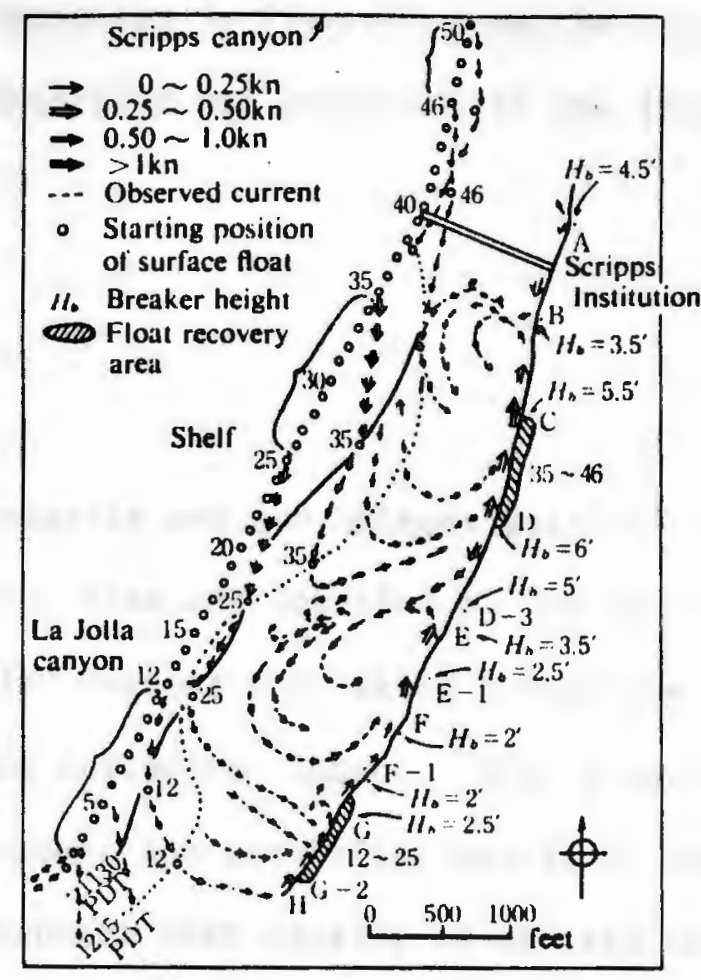

Typical nearshore circulation pattern (after Shepard and Inman, 1950).

Figure 1-4 Nearshore Current System

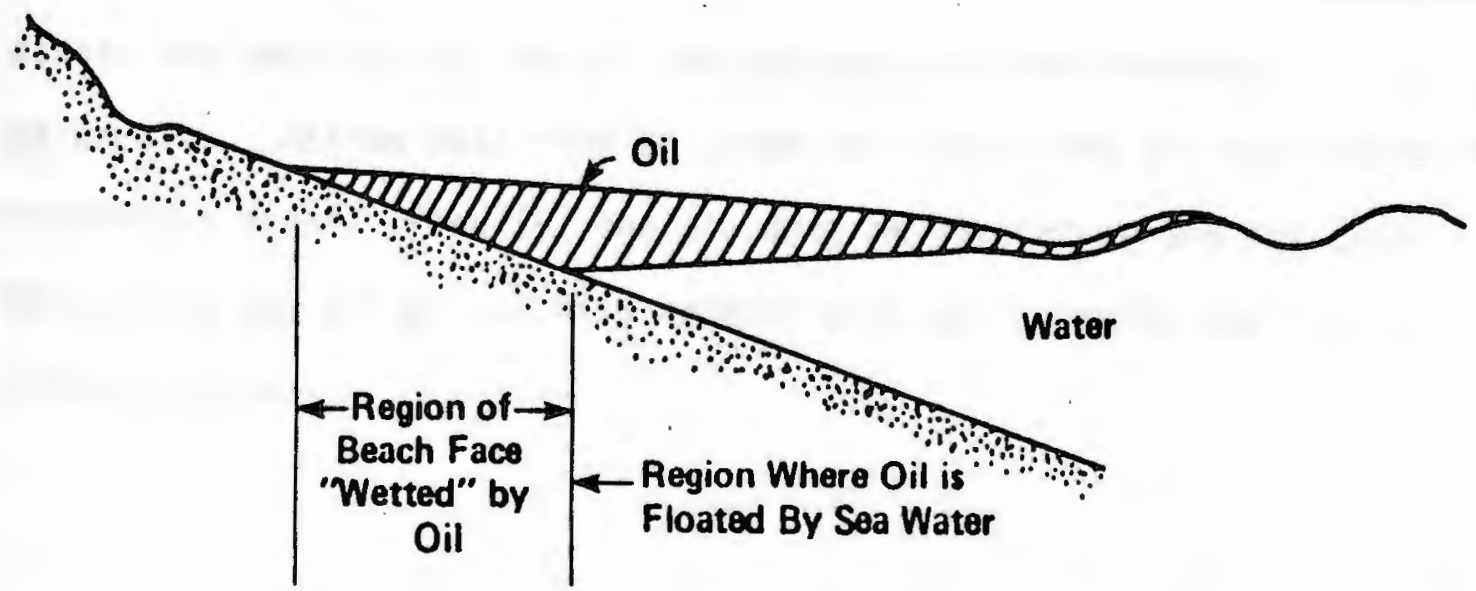

Suggested cross section through an oil pool held against the beach face by wind and wave stress.

Figure 1-5 Beach Cross Section 
Some of the other processes in Figure 1-1 may be important in special cases, but are generally not addressed in the literature and poorly understood.

\section{Responses}

The reasons for a response and the methods used can vary greatly and are determined by the size, time and location of the spill and the oil's characteristics. The major reasons for taking action are to protect human life and to minimize ecological impact. Some alternate motives are to minimize the socio-economic and aesthetic impacts of the spill. A trade-off between these aspects must usually be carried out since funds and manpower are generally limited. Trade-offs can also be influenced by outside considerations such as heavy weather, eliminating any. possibilities of response, or political pressure.

There are many steps which constitute a response, and the magnitude of the response varies from spill to spill. An on-scene coordinator must assess the behavior of the $0 i 1$ and evaluate all environmental

parameters. Action must then be taken to contain the oil and protect any vulnerable areas. Finally, the oil must be cleaned up and any areas damaged by the oil or response methods must be recovered and rehabilitated. 
Organization of responses to oil spills begins at the national level. Regulations were initiated in 1968 with the National Multiagency $0 i 1$ and Hazardous Materials Contingency Plan (Sittig 1974) and updated in the 1970's by the Federal Water Pollution Act (Federal Register 1975). This legislation delegates the U.S. Coast Guard as the agency which monitors potential spill sites, inspects oil facilities, enforces the regulations, prescribes fines and supplies the on-scene commander (OSC) for marine spills not in inland waters. The coast Guard also oversees and instructs regional and local officials in a response. The legislation authorizes equipment purchases and designates the responsibilities of other parties such as the Environmental Protection Agency and the Department of Defense.

At the local level, the Coast Guard has supplied a format to be followed for contingency plans which include plans of organization and areas of responsibility (U.S. Coast Guard 1978). Local authorities have expanded the plans to include details of response (Garry 1981), as we 11 as site-specific considerations (Bell 1981, and Hum 1977).

In the private sector, companies which are involved in some aspect of the oil business have developed plans and purchased equipment in order to protect themselves from liabilities which may occur if oil is spilled at their facility. A company has two options if the purchase of equipment is not practical. The first alternative is to join a cooperative in which each of the companies have invested in equipment and 
training to decrease costs to individual companies (Franklin 1977 , Hubbard and Allen 1979). The second method is to rely on outside contractors. These contractors, generally set up for the sole purpose of cleaning up oil and other hazardous materials, are utilized by federal and local authorities as well.

There are many examples of actual responses in the literature and a review of these show the varying conditions, the wide range of responses and the complex problems which may be encountered during a spill. A large response was made to the Argo Merchant spill of 1976; however, there was no resultant clean up since the ofl went out to sea (Argo Merchant 1978). The response during the Amoco Cadiz spill of 1978 was complicated when wind and currents moved oil back to some shoreline which had already been cleaned (Hess 1978). The organization of a response team can be complicated (see Figure 1-6), inhibiting quick decisions. Daily problems which are encountered include break down of equipment such as occurred during the IXTOC I blowout (O'Brien 1981) or equipment delivery delays in the case of the Argo Merchant spill. Another problem is that the impact of public pressure on the on-scene coordinator can affect decisions.

A major recurring problem is the damaging actions performed by ignorant or incompetent personnel. For example, White (1979) has documented a case in which heavy equipment contractors attempted to recover oil on a beach but only increased the difficulty of recovery by 


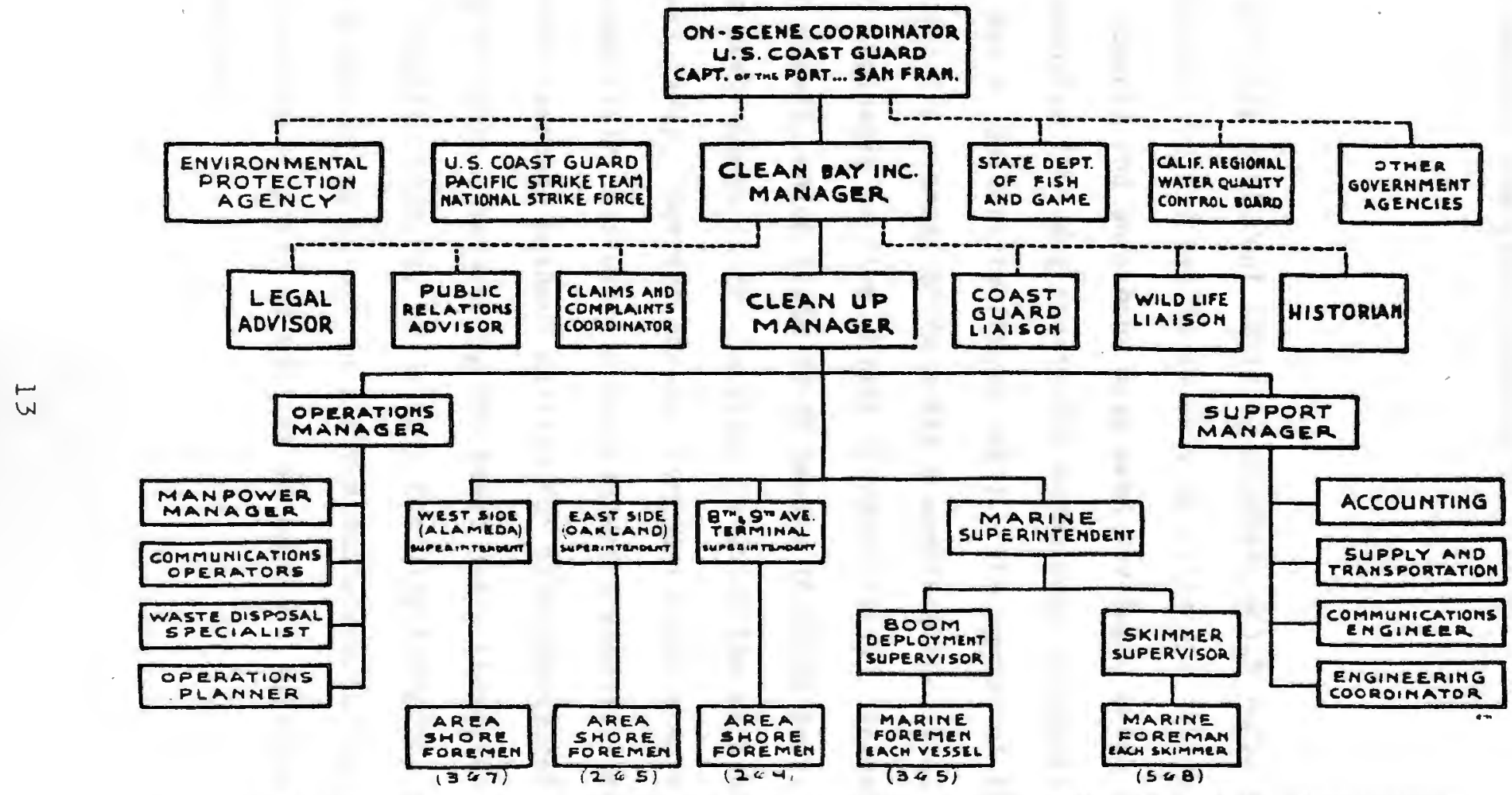

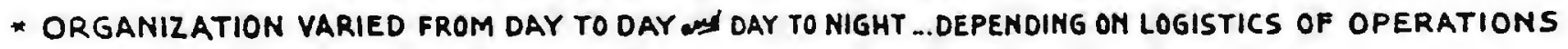

Oil spill composite organizatıon for the Oakland estuary spill cleanup

Figure 1-6 Cleanup Organizational Chart 
pushing the oil deeper into the sand with their vehicles. Other contractors have used hoses with 7,000 psi water pressure to clean a marsh, destroying the roots of the remaining vegetation in the process (Owens and Foget 1982). The problems can clearly be overcome by proper training of managers and other personnel.

\section{Training}

There are many different training programs which focus on different aspects of combatting oil spills as well as different levels of personnel. Schools and workshops have been developed which may last 2-5 days. An intensive five-day course for management personnel is offered at Texas A. and M. University (Payne 1981). The agenda of this course is shown in Figure 1-7. Great Britain has a workshop for local managers, such as town engineers or fire chiefs (Cormack 1977). Traveling workshops in Canada, which train 20-30 people in three days, are adapted to cover the environment in the location in which the workshop is offered (Zimlick-Owens 1979). Shorter one-day seminars cover a more limited field. Ouerden (1979) discusses a program which enables local fireman to begin a limited response without waiting for other personnel to arrive. Role-playing has been developed by the Coast Guard (Kangeter 1977) and for private industry (Marcus, 1977) as a training technique. Both of these allow a manager to be put in a situation where he/she must make decisions regarding a spill, as well as to fend off political or public relation problems. 
Other aids include manuals for an on-scene commander (Foget 1979 and Byroade 1981), video tapes and $16 \mathrm{~mm}$ film with manuals (Kay 1977), as well as instruction books for the general public (Omohundro 1980a and 1980b).

Tibbets (1975) has developed a program to assemble a total response team. In this method, after developing an organizational chart and job descriptions for each position, personnel are assigned a post. Seminars are run to teach the responsibility of each individual and how each position is interrelated. Practice sessions can be run periodically to keep personnel up to date.

\section{A Training Alternative}

All of the above training techniques require large amounts of time, money and manpower. An alternative training technique which might be used is a computer. This research, discusses an interactive computer model which has been designed as an aid in the training of personnel by allowing them to experiment with different responses to an oil spill. First, existing models of the various processes and spill responses were reviewed. Those processes and responses thought to be appropriate were incorporated into an existing composite model and new methods for those either not modeled or unsuitably modeled were developed. The result is an integrated training program which determines the impact of a spill and the effectiveness of the responses selected by the user. In the last chapter, the capability of the model is demonstrated by several examples. 
Figure 1-7

Oil Spill Control Course Agenda

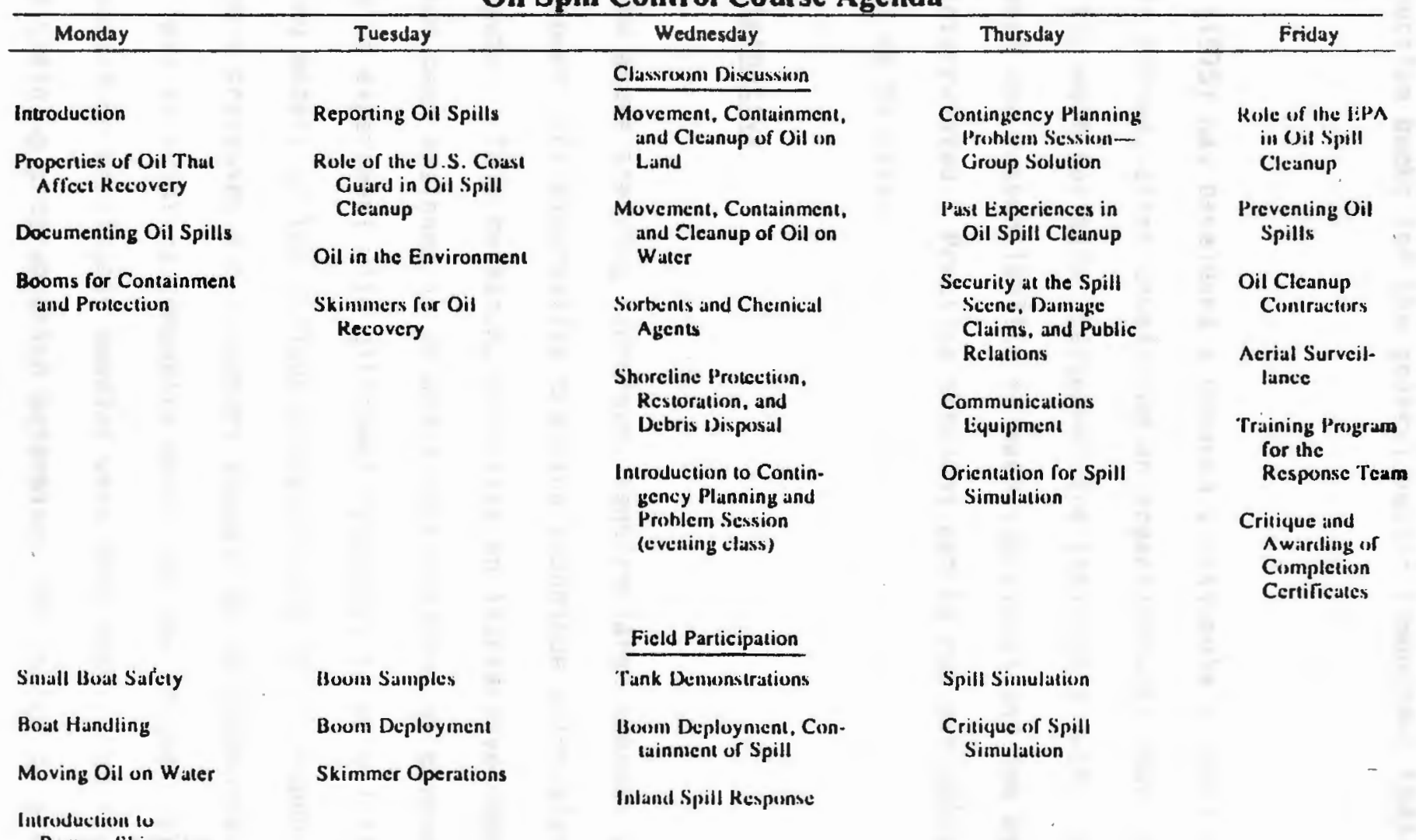

Pumps, Skimmer

and Equipment 
CHAPTER II

COMPUTER MODELING

In evaluating existing computer models, it is important to remember that most of them are usually designed for a specific task. Mackay (1978) has divided them into five types as shown in Table 2-1. All of the categories, except the real time one, serve as research tools which investigate oil behavior or the effect of oil on a location. The research models are used as "testing ground" to test specific sites and processes or to hindcast an actual event. The real time trajectory models are designed to aid the on-scene commander in making decisions based on predicted oil movement.

The purpose of this research has been to develop a new type of model to be used as a training tool. This training model uses historical data as input into a model which includes surface and subsurface processes as well as modeling response techniques. It allows a user to rerun a sample spill with simulated responses as many times as needed until an optimum response is attained.

\section{Model Selection}

The first step in constructing the model was to locate an existing program which could be used as a building block. Models are usually 
Table 2-1

(Frou Mackay, 1978)

\begin{tabular}{|c|c|}
\hline Characteristics & $\begin{array}{l}\text { Real Tine Sp1ll } \\
\text { Trajectory }\end{array}$ \\
\hline Purpose & $\begin{array}{l}\text { To facilitate } \\
\text { countermensures, } \\
\text { poseibly in "gage" } \\
\text { os wall os actual } \\
\text { spill form }\end{array}$ \\
\hline User & $\begin{array}{l}\text { On-scene-comander } \\
\text { nctual and tralalag }\end{array}$ \\
\hline $\begin{array}{l}\text { Progras } \\
\text { Accessibility } \\
\text { and Speed }\end{array}$ & $\begin{array}{l}\text { Accessible in remote } \\
\text { reglons, results } \\
\text { avallabie lo I hour } \\
\text { uthout consultation } \\
\text { with developar. } \\
\text { Hust thus be simple } \\
\text { and robust and } \\
\text { easily used. }\end{array}$ \\
\hline $\begin{array}{l}\text { Environmental } \\
\text { Data Input }\end{array}$ & $\begin{array}{l}\text { Real tine wind, } \\
\text { current, t1dal, } \\
\text { westher data, and } \\
\text { local geography } \\
\text { and bathynetry }\end{array}$ \\
\hline
\end{tabular}

011 Type

Output

Status

spilled oll.

Propertios must be

"looked up"

Fast visual display readily ass lullabl. cathode ray tube or computer graph preferred

Several exist
Environmental

Iupact Assesament Research Scenar 10

(Phye1cal

lological

Model

To provide an

Assessment of $11 \mathrm{kely}$

mapers of a

proposed development

To obcaln and

validate sclentific

f Indinge and

to provide an

issessment of 11kely

cological offect.

plan exper tments

Proponents and revlever: of the developanat

Research scleatiet

$310 \log 18 t /$ Ecolog1st

Several daye delay

Avallable only to

a few lndividuals

pro co consule with

programer. Falr

complexicy acceptable

by several groups

or even the progra

alone. Long dalay

acceptable. Any

acceptable

Hiatorical wind

current, cidal,

weather date, 1.e.

mouthly everages

Usually several

selected "typical"

conditions

Is Research Hodel

Average veather and otber cond 1t loos

Egt 1mate of the oll or olls 11kely to be spllled and range

of sounts and

tion of actur

More complex and slowly ascimilable data accaptable but preferable converted into visual form in report, e.g... overlays

Specif ic oll and amount selected

As Research Hodel

Complex tabulations acceptable. Can be connected co visual forw for reporting

Several exist

jery few

To provide an

overall, long term

asseasment of inpact

and bexard for a

leks or sea

Enylxonnental

Selenctac/Planner

As Resenrch Model

Escinates of annual amounts spllled and average propertles

As Research Model

Simple wass balances prefer in visual form for report

ac leisure

A feu exist

Very fer 
evaluated by assessing the validity of the processes modeled. There have been three major reviews of modeled processes since 1977. Stolzenbach et al. (1977) reviewed techniques for modeling surface oil processes, concentrating on advection. In 1982, Davidson and Lawrence were searching for a trajectory model to be used for offshore work. They reviewed 15 models for advection, spreading, evaporation, dissolution, and emulsification as well as surface diffusion and vertical diffusion. Surface diffusion, used to model small scale effects which are not included with wind and current advection, is defined by the reviewers as another form of advection, and vertical diffusion is another name for dispersion. The most extensive review is that of Huang and Monastero (1982) who reviewed 35 models (see Table 2-2). The reader desiring more detall concerning modeled processes is refered to these reports. Models on the list in Table 2-2 are referred to numerous times in the following paragraphs. The processes which are contained in these models are summarized in Tables 2-3 and 2-4.

A brief description of the methods used for modeling oil spill processes is presented below. Not all techniques are discussed, only those which are generally accepted being included. Little field data has been collected concerning these techniques, with few significant advancements made in most methods used since 1978.

Fay developed a model which balances the forces of gravity, inertia and friction to determine the rate at which oil spreads (Stolzenbach et al. 1977). This method, which gives a good order of magnitude to the 
Table 2-2 0il Spill Simulation Models Reviewed

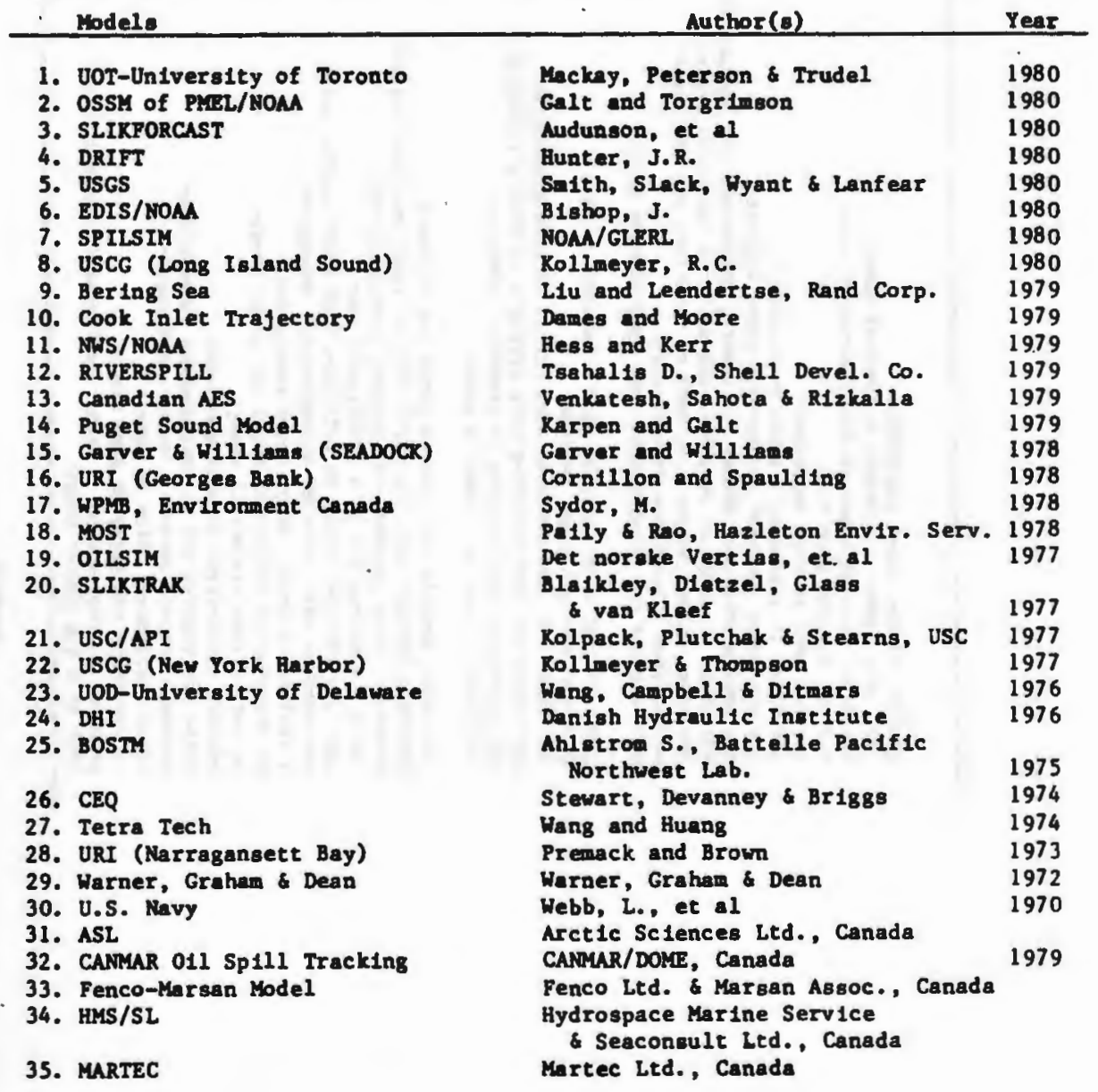


Table 2-3. Model ing Technology of Adyection

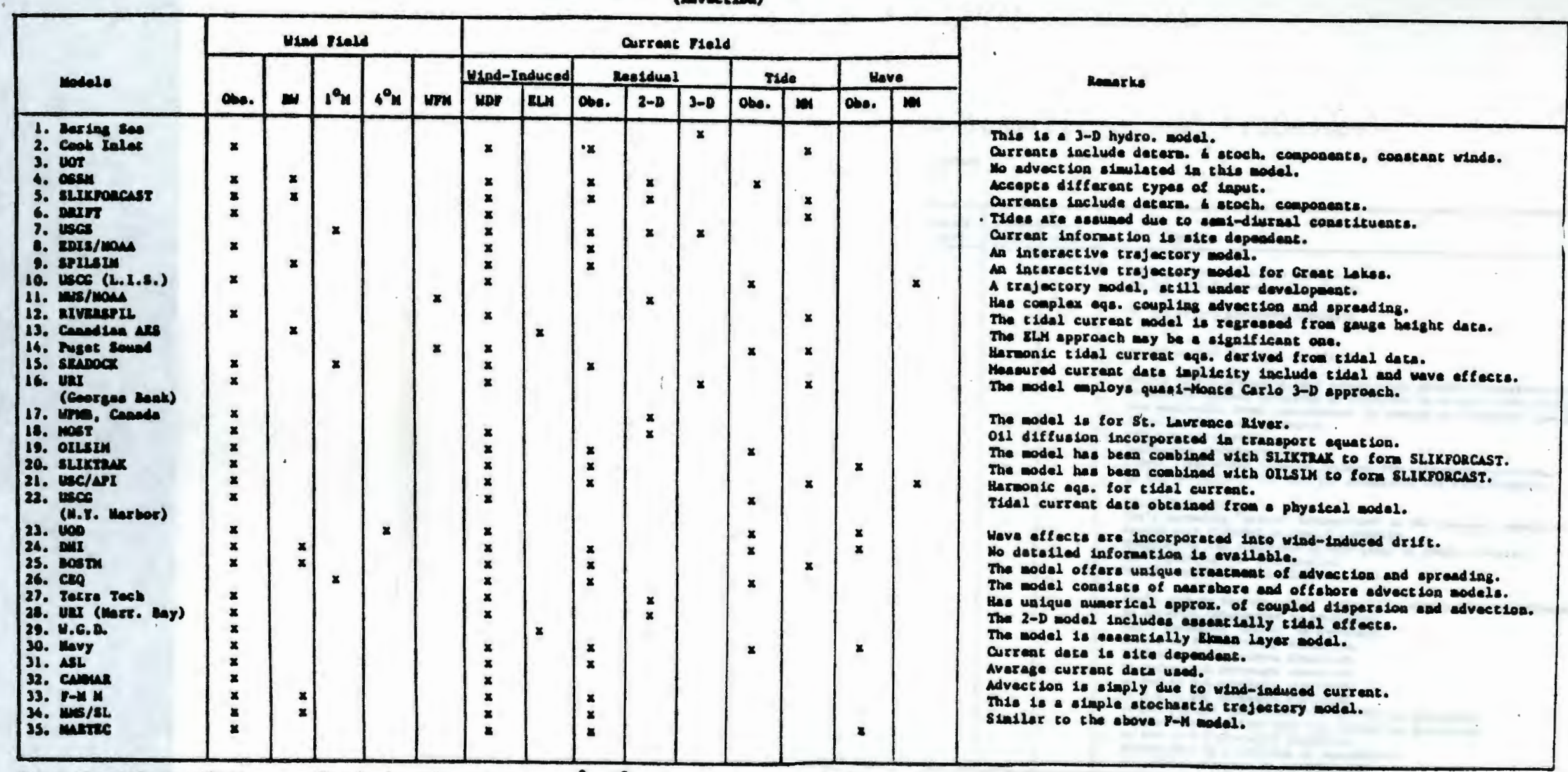

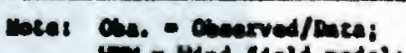

mo tondin mik procens;

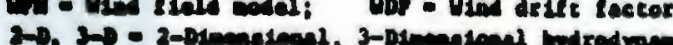

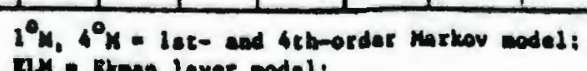

Thle 1e 3-D hydro. codel.

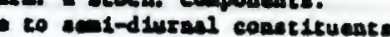

ta interective trejectery model for Great Lekes.

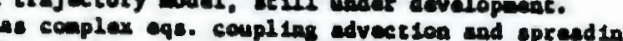

the

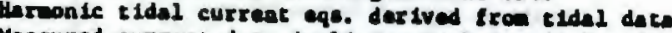

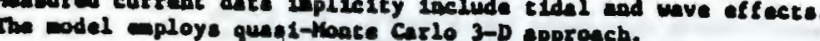

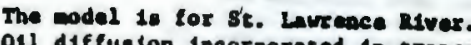

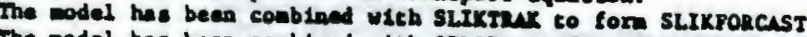

the

bryeseal eodel.

the nodel offere vat gue creatume of advection and sprand ing.

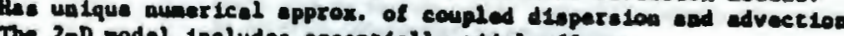

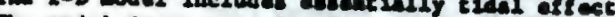

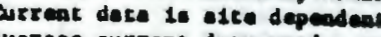

Mdvect ion to siaply due to utad-10duced curreot.

nin - Dhan Layar modeli 
Table 2-4 Modeling Technology of Physical/Chemical/Biological Processes

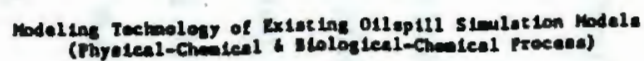

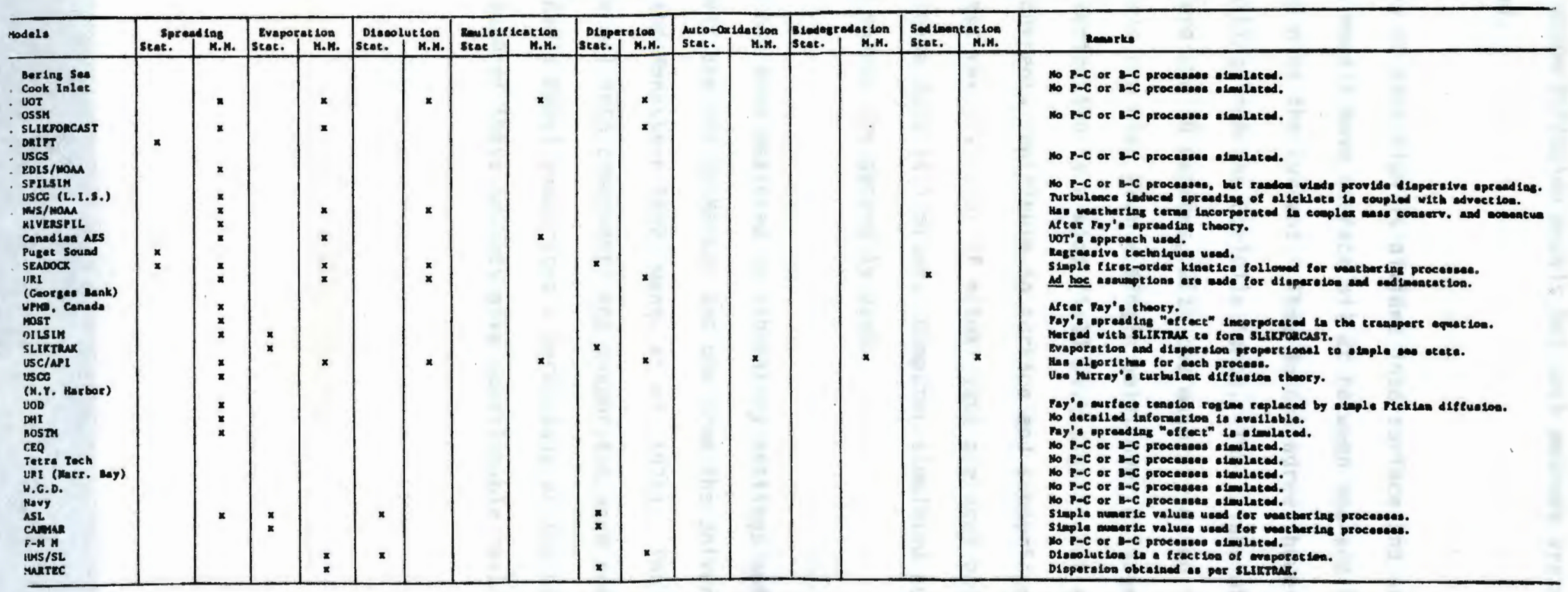

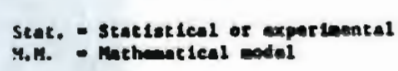


size of a spill as a function of time, is used in most models. It has however not been proven to work in high sea states. Other researchers are developing random diffusion models but such methods are not yet common ly accepted.

The modeling of advection is divided into surface and subsurface oil transport. Most models move surface oil at between one and five percent of the wind speed plus the current. They do not agree, however, on a drift angle resulting from the coriolis force. The values of the angle varies between zero and 30 degrees, with the majority using no drift angle. Most models use wind from a single point over a large area. This is a poor parameterization in a wind field with significant shear present. Water currents contribute to surface and subsurface oil movement. The best results occur if actual data are used but the availability of these data is limited. Computer simulated current or inferred current values are generally used.

Evaporation has been measured in laboratory settings and the two most popular models are one by Mackay and one from the University of Delaware (Huang and Monastero 1982, Wang, et al. 1976). The Delaware model divides the $0 i 1$ into components and evaporates each component separately. MacKay's model evaporates a percentage of the oil based on its thickness. Both of these methods give questionable results in high sea states. 
Dissolution occurs at a slow rate and is ignored in most models. The technique used in the University of Toronto (UOT) model (see Table 2-2) is based on observational data and could be adopted with extensive experimentation. The USC/API model determines the rate of dissolution as a function of six parameters but these are difficult to measure and no experimental data are available to support this method. Less sophisticated models tend to group dissolution and dispersion together and use a constant rate which is a function of time, temperature and/or sea state. The only real data has been collected by Audunson (1982). Both the URI and the SLICKFORCAST models use these.

Emulsification is a difficult process to simulate because little is known about the factors which affect it. A simple method is used in the SEADOCK model. This technique arbitrarily reduces the oil present by one percent when the wind speed is greater than $20 \mathrm{mph}$ and the spill is in shallow water. Complex models, such as the Toronto and the USC/API models, contain comprehensive emulsification models but these are empirically based and require a significant amount of input data which is not easily obtained.

At this time, no model contains feasible techniques for photo-oxidation, biodegradation and sedimentation. Most models also do not provide for shoreline interaction. In general, the oil trajectory is simply terminated at the shoreline. The modeling of processes still needs to be developed but most of the composite models perform adequately in simulating the specific tasks which they were designed for. 
Many of the composite models could be used as a basis for the work discussed below. The OSSM model and the Drift model by Hunter can be run interactively but lack subsurface processes. The SEADOCK and SLICKFORCAST models also lack some processes. The Toronto and USC/API models are extensive but have a mixture of theoretical and empirical processes which are too complex. The Massachusetts Institute of Technology has published a model (0il Spill clean-up 1981) but its emphasis is on economic impact and regulation and does not contain a sophisticated oil behavior model. The University of Rhode Island model has most of the processes needed and is simple, flexible and easily accessible. It has been selected as the base for the work presented here.

\section{Modeling Responses}

There are two general approaches for modeling oil spill responses. The first method is to model a specific response, such as a skimmer, to determine the cost of the effort and the result that it has on the mass balance of a spill. In addition to modeling general responses, computers have been used to investigate and/or plan specific components. Swanson and Spaulding (1980) have taken a mathematical model by Cross and Hoult (1971) which simulates the interaction of oil with a boom, and combined it with real data from Abrahams (1977). The result is a model of boom effectiveness although in the technique has not been verified 
experimentally. A second approach is to assume cleanup parameters such as cleanup rate and efficiency and to use these as input into a composite model which determines the probability that the oil will come ashore. These approaches may be programmed on a computer or performed by hand. Cochran et a1. (1975) assumes environmental and equipment characteristics and calculates the mass balance. Table 2-5 shows a sample spill of 10,000 barrels with cleanup responses utilizing a skimmer and a boom. Skimmer and dispersant responses were studied by Holmes (1977). Table 2-6 shows a typical calculation for responses utilizing two skimmers and a dispersant spraying unit. Fraser (1979) utilizes several of the models listed in Table 2-2. Numerous runs are performed using Cochran et al. (1975), Blaikley (1977), the BOSTM model (No. 25, Table 2-2) and RIVERSPILL (No. 12) with the probability of oil coming ashore at a given location being determined. The results are then used to determine the type, location, and amount of cleanup equipment needed. Audunson (1980) assumes a cleanup efficiency based on sea state and then uses the SLICKFORCAST model to determine the probability of the oil reaching land. None of these models however contain enough detail to simulate a reasonable cleanup technique.

Another use of computers is the U.S. Coast Guard's data base of cleanup equipment. This data base, called SKIM, stores the characteristics of twenty-six types of equipment along with their location and owner. In addition, the Coast Guard in New Haven has utilized a microcomputer for contingency planning (Harrald and Conway 1981). They have stored charts of the Long Is land Sound area for which 
Table 2-5 Sample of Simulation (Cochran et al. 1975)

\begin{tabular}{|c|c|}
\hline \multicolumn{2}{|c|}{ INPUT DATA } \\
\hline 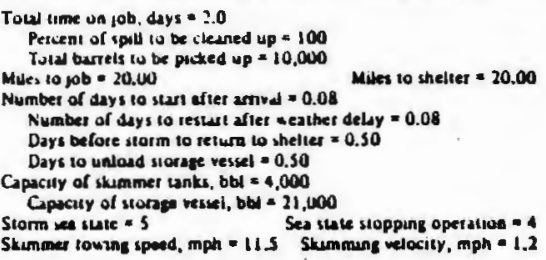 & 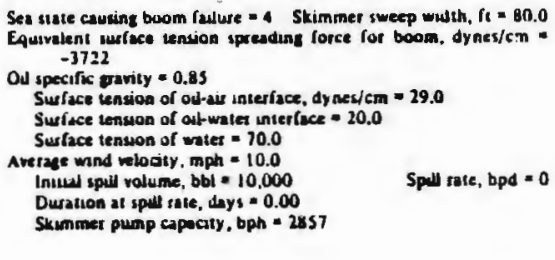 \\
\hline 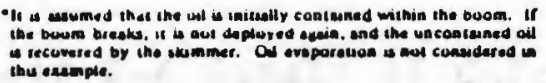 & \\
\hline
\end{tabular}

Culf-winces thummes B (Sturases specticauons un Lable 2)

Days required fot enture job $=\mathbf{2 . 0 0}$

Towl od splled, bol $=10,000$

ON recovered, bbl $=5,444$.

Toul liqued recurered, bol $=14,499$

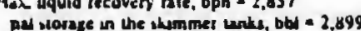

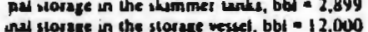

The storage vessel went to post 0 times ind took a toul of 0 time The storape rese

Stumening was halied 0 tumes diw to lack of stange upuce in the slocage vesult.
Skimming wat helted 1 ume by rouch wess and waiked a total of 3 tume pernods on the job vite

Stumaing was halled of prevented 0 tumes by s utarm and 0 ume

38 ume periods were spent skimmung and 3 time penods wete spent uransemse

Houm raved at 10 time pertods

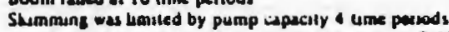

Ave. recovery tale durng ihs sume could have been 1,858 bph

Days requered to travel to job $=0.09$

Daye spent on job ute $=1.92$

\begin{tabular}{|c|c|c|c|c|c|c|c|}
\hline $\begin{array}{l}\text { Time } \\
\text { Penod } \\
\text { (hour) }\end{array}$ & $\begin{array}{c}\text { Sea } \\
\text { Sisuce }\end{array}$ & $\begin{array}{c}\text { Out } \\
\text { Spulled } \\
\text { (bul) }\end{array}$ & $\begin{array}{l}\text { Aves } \\
\text { Concamunaled } \\
\text { (\&. mile) }\end{array}$ & $\begin{array}{l}\text { Oil } \\
\text { Muckness } \\
\text { (in) }\end{array}$ & $\begin{array}{c}\text { Ou } \\
\text { Recovered } \\
\text { (bou) }\end{array}$ & $\begin{array}{l}\text { Toual } \\
\text { Liquid } \\
\text { Recovered } \\
\text { (bb) }\end{array}$ & $\begin{array}{l}\text { Comments } \\
\text { (wee notes } \\
\text { betow) }\end{array}$ \\
\hline 0 & 3 & 10,000 & 0.000 & 0.00000 & 0 & 0 & \\
\hline 1 & 3 & 10,000 & 0.008 & 3.03879 & 0 & 0 & \\
\hline$i$ & 3 & 10,000 & 0.008 & 3.03879 & 0 & 0 & 1 \\
\hline j & j & 10.000 & 0.008 & 3.03479 & 0 & 0 & \\
\hline 4 & j & 10.000 & 0.608 & 3.03879 & 0 & 0 & 2 \\
\hline 5 & J & 10,000 & 0.008 & 2.74968 & 95i & 2,857 & \\
\hline 6 & $\mathbf{3}$ & 10,000 & 0.008 & 2.63402 & 1,312 & 4.000 & \\
\hline$\overline{7}$ & 3 & 10,000 & 0.008 & 2.63402 & 1,332 & .000 & 3 \\
\hline 8 & 3 & 10,000 & 0.008 & 2.34492 & 2.283 & 6,857 & \\
\hline 9 & 3 & 10,000 & 0.008 & 1.22926 & 2,664 & 8.000 & \\
\hline 10 & 4 & 10,000 & 0.008 & 2.22317 & 2,060 & 8,000 & 3.4 .3 \\
\hline 11 & 3 & 10,000 & 0.074 & $0.241 \geq 0$ & 2.664 & 8,000 & \\
\hline 12 & 3 & 10,000 & 0.118 & 0.15025 & 2,664 & 8.uvo & \\
\hline ij & 3 & 10,000 & 0.163 & 0.10860 & 2,6004 & 1.600 & \\
\hline 14 & 3 & 10.000 & 0.209 & 0.08198 & 2.925 & 8,966 & 6 \\
\hline is & 2 & 10,000 & 0.254 & $0.06+52$ & 3,122 & 9.950 & \\
\hline 16 & $\boldsymbol{I}$ & 10,000 & 0.307 & 0.05075 & 3.544 & 10,724 & \\
\hline 17 & $i$ & 10.000 & 0.361 & 0.04092 & 3,883 & 11.334 & \\
\hline ia & 2 & 10,000 & 0.419 & 0.03309 & 4,153 & $11.82 \mathrm{~s}$ & \\
\hline 19 & 2 & 10.000 & 0.063 & 0.02475 & 4,249 & 12,000 & \\
\hline 20 & 2 & 10,000 & 0.552 & 0.02517 & 4,249 & 12,000 & $\mathbf{3}$ \\
\hline 21 & 2 & 10.000 & 0.622 & 0.02171 & 4,415 & 12,302 & \\
\hline 22 & 2 & 10,060 & 0.099 & 0.01892 & 4.559 & 12,563 & \\
\hline 23 & 2 & 10,000 & 0.171 & 0.01066 & 4,644 & 12,790 & \\
\hline 24 & 2 & 10,000 & 0.851 & 0.01479 & 4,794 & 12,990 & \\
\hline 25 & 2 & 10,000 & 0.933 & $0.0132\}$ & 4.891 & $13,16 \mathrm{~d}$ & 7 \\
\hline 26 & 2 & 10,000 & 1.019 & 0.01191 & 4,979 & 13.327 & \\
\hline 21 & 2 & 10,000 & 1.107 & 0.01079 & 3.057 & $13,4: 0$ & \\
\hline 28 & 2 & 10,000 & 1.198 & 0.00982 & 5.129 & 13,599 & \\
\hline 29 & 2 & 10,000 & 1.292 & $0.00 \$ 99$ & 3.194 & 13,717 & \\
\hline 30 & 2 & 10.000 & 1.389 & 0.00826 & 3,253 & 13,825 & \\
\hline 31 & 2 & 10,000 & 1.487 & 0.00762 & 9,307 & 13,924 & \\
\hline 32 & 2 & 10,000 & 1.589 & 0.00706 & 5.358 & 14,016 & \\
\hline 33 & 2 & 10,000 & 1.692 & 0.00656 & 3.404 & 14.101 & \\
\hline 34 & $i$ & 10,000 & 1.798 & 0.00612 & 3.448 & 14,179 & \\
\hline 35 & $i$ & 10,000 & 1.907 & 0.00572 & S.448 & 14,253 & \\
\hline 36 & 2 & 10,000 & 2017 & 0.00516 & 5,526 & 14,321 & \\
\hline 37 & $i$ & 10,000 & 2.130 & 0.00507 & 5.561 & 14,386 & \\
\hline 38 & 2 & 10,000 & $2.2+5$ & 0.00474 & 5,595 & 14,446 & \\
\hline 39 & 2 & 10,000 & 2.362 & 0.00440 & 5.626 & 14,503 & \\
\hline 40 & 3 & 10.000 & 2441 & 0.00423 & 3.656 & 14,597 & \\
\hline $4 !$ & 2 & 10,000 & 2.602 & 0.00401 & 5.683 & 14,608 & \\
\hline 42 & 2 & 10,000 & 2.725 & 0.00310 & 3.710 & 14.636 & \\
\hline 43 & 2 & 10.000 & 2.150 & 0.00362 & 5,735 & 14,702 & \\
\hline 4 & 2 & 10,000 & 2.977 & 0.00344 & 3.739 & 14,745 & \\
\hline 45 & 2 & 10,000 & 3.106 & 0.00328 & 3.782 & 14,780 & \\
\hline 46 & 2 & 10,000 & 3.236 & 0.00313 & 5,801 & 14,826 & \\
\hline 47 & 2 & 10,000 & 3.169 & 0.00300 & 5,014 & 14,203 & 8 \\
\hline
\end{tabular}

NoTEs:

J. Stummer arrive ot ipd nis.

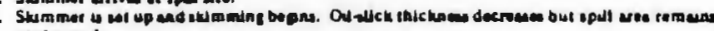

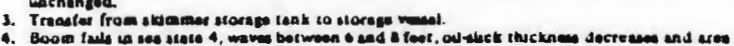

Boom inits

Stornmings stopped in ane stato 4 .

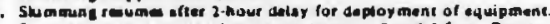

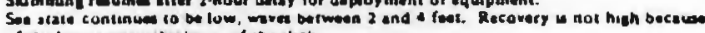

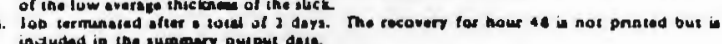

lest 
Table 2-6 Sample of Calculations (Holmes 1977)

Offshore situation using two skimmers ( $2 \times 600$ ton/day) plus one spray unit ( $1 \times 270$ ton/day)

\begin{tabular}{lrrrrrr}
\hline & Day 1 & Day 2 & Day 3 & Day 4 & Totals & $\%$ \\
\hline Oil at start (tons) & 5,000 & 3,613 & 1,514 & Return & & \\
Oil evaporated (\%) & 15 & 10 & 5 & to buse & & \\
Oil evaporated (tons) & 750 & 362 & 76 & & 1,188 & 24 \\
Oil remaining (tons) & 4,250 & 3,251 & 1,438 & & & \\
Oil skimmed (tons) & nil & 1,200 & 1,200 & & 2,400 & 48 \\
Oil remaining (tons) & 4,250 & 2,051 & 238 & & 508 & 10 \\
Oil dispersed (tons) & nil & 270 & 238 & & & \\
Oil remaining (tons) & 4,250 & 1,781 & nil & & & \\
Natural dispersion (\%) & 15 & 15 & - & & 904 & 18 \\
Natural dispersion (tons) & 637 & 267 & - & & & \\
Oil remaining (tons) & 3,613 & 1,514 & - & & 5,000 & 100 \\
& & & & & & \\
\hline
\end{tabular}

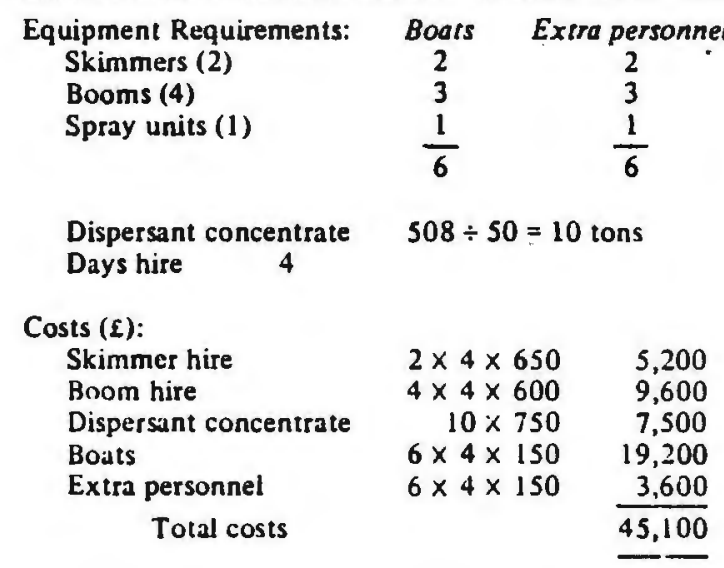




\section{CHAPTER III}

\section{MODEL DEVELOPMENT}

The University of Rhode Island model was developed by Cornillon and Spaulding (1978). This model has been designed to be modular so that as new algorithms are developed, they can easily be integrated into it. It was inftially used to determine the impact of an oil spill on the fishing industry of Georges Bank (Cornillon et al. 1979). Details of the computer program with sample applications is presented in "Assessment of Treated vs Untreated Spills, Final Report", [Mason, Wilson ed.] (1980). More recent applications are summarized by Reed and Spaulding (1982). In this chapter, the processes modeled by Cornilion and Spaulding are briefly described; more extensive descriptions of the processes and assorted algorithms exist in the literature. This is followed by a detailed description of additions made to the model as part of this research.

\section{URI Model}

For the URI model, oil on the surface of the water is modeled as individual spillets or pancakes. Each spillet is an independent entity having its own mass, volume, oil composition and radius. Spillets are acted upon by all processes and are not affected by the presence of other spillets. 
The subsurface regime is modeled with advection and diffusion as developed by Spaulding (1976). 0 il in the water column is modeled as discrete droplets, each representing a specific amount of mass having unique oil properties. A floating three-dimensional rectangular grid is set up around the particles and is used to calculate the concentration based on the number of particles in each grid cell. The model then determines a diffusive velocity which is added to the current field.

The model as developed includes the following processes:

1) advection: A wind drift factor and drift angle is used for moving the surface spillets. These values cannot be easily changed by the user. They can however be modified in the computer code. Currents transport the subsurface particles and add to the surface advection. These currents can be entered in any detail desired by the user.

2) spreading: Fay spreading (Stolzenbach, et al., 1977) is used for each spillet. This model allows variations in oil volume and interfacial tension due to the other processes involved. This permits individual spillets to enlarge or shrink depending on other processes or cleanup actions. 
3) evaporation: The University of Delaware evaporation model is used. This model specifies eight classes of hydrocarbons and defines various oils by the percentage of each class which that oil contains. The rate at which each class evaporates is then calculated as a function of wind speed and temperature. (Wang et al. 1976)

4), dispersion: Data is taken from Audunson (1980) which gives a percentage of oil dispersed as a function of windspeed. An average value is on the order of 10 percent per day for wind of $8.5 \mathrm{~m} / \mathrm{sec}$. Weathering is accounted for by including an exponential decay with a time constant of two days so the rate slowly reduces with time.

\section{Shoreline Processes}

An important process for the training of personnel in the response to spills is the interaction of the spill with the shoreline. This process depends on the nearshore oceanographic process. Thomas (1975) and Winant (1980), have discussed wind-induced circulation in a shallow water environment. Shepard and Inman (1980) and Birkeier and Dalrymple (1975) have developed empirical equations for nearshore currents. These are just a few who have investigated nearshore processes. The modeling 
of these complex currents requires large amounts of wave, wind, bathymetic, and beach slope data. Because such detail greatly exceeds our level of understanding of oil-shore interaction, it is inappropriate for this research. Instead, a simple method simulating the general movement of oil along a shoreline is used. As understanding of the spill-shore interaction improves, more sophisticated nearshore processes can be included.

The shoreline interaction routine developed here tracks the center of the spillet and prevents it from crossing the shoreline. After intersecting the shoreline, spillets are constrained to move parallel to it with the parallel velocity component. The spillet is moved away from the coast when it reaches the end of a shoreline segment or the end of a time step. A given percentage of oil from spillets intersecting the coastline is deposited on shore at the end of each time step. Subsurface particles use the same basic scheme although the entire particle is deposited on the first shoreline interaction. Details of these algorithms are contained in Appendix $A$.

A shoreline classification system is used in the model both for the shoreline interaction and response methods. It is based on the work of Gundlach and Hayes (1978) who developed the classification system shown in Table 3-1. Complicated and time consuming field studies are needed to determine the shoreline composition, wave energy, and tidal dynamics in order to classify a coastline. This classification may also vary for 


\section{Table 3-1 Shoreline Classification system (Gundlach and Hayes 1978)}

Summary of Proposed Environmental Classification in Order of Increaeing

Vulnerability to Oil Splil Demage

\begin{tabular}{|c|c|}
\hline $\begin{array}{l}\text { Vulnorability } \\
\text { index }\end{array}$ & Shorellne Type \\
\hline 1 & $\begin{array}{l}\text { Exposed rocky head- } \\
\text { lands }\end{array}$ \\
\hline 2 & $\begin{array}{l}\text { Erooling wave-cut } \\
\text { platlorms }\end{array}$ \\
\hline 3 & $\begin{array}{l}\text { Fine-grained aend } \\
\text { beaches }\end{array}$ \\
\hline 4 & $\begin{array}{l}\text { Couraegrained } \\
\text { aend beachee }\end{array}$ \\
\hline 5 & $\begin{array}{l}\text { Exposed, compacted } \\
\text { lidal flats }\end{array}$ \\
\hline 6 & $\begin{array}{l}\text { Mixed sand and } \\
\text { oravel benches }\end{array}$ \\
\hline 7 & Gravel benches \\
\hline 8 & $\begin{array}{l}\text { Shellered rocky } \\
\text { coasts }\end{array}$ \\
\hline 9 & $\begin{array}{l}\text { Sheitered tidal } \\
\text { tlats }\end{array}$ \\
\hline & \\
\hline 10 & $\begin{array}{l}\text { Salt marshes and } \\
\text { mangroves }\end{array}$ \\
\hline
\end{tabular}

Commenta

Wave reflection keeps moat of the ofl off-ahore. No clean-up ts necessary.

Weve swept. Most oll removed by natural processes within wooks.

Oll doesn't penetrate into the sediment, tacilliating mechanical removel II neceasary. Olherwise, olt may persist soveral months.

Oll may aink andior be burted rapidly making cleen-up diflicult. Under moderate to high energy conditions, of will be removed naturally within monthe from most ot ine beachface.

Most ofl will not adhere to, nor penatrate into, the compacied lidal flat. Clean-up is uaually unnecesany. Olt mey undergo rapld penatretion and burlat. Under moderate to low energy conditions, ofl may peralst for yeare. Same as above. Clesen-up anould concentrate on the high. tide awash area. A solld asphall pavement may torm under heavy ofl eccumulations.

Aress of reduced wave ection. Oll mey pertalst for meny years. Clean-up is nol recommended uniess oil conceniration is very heary.

Areas of great blologic activity and low wave energy. Oll may persist for years. Clean-up is not recommended uniess oll accumulation is very heary. These areas shovilu recelve priority protectlon by using booms or oll sotbent materials.

Most productlve of aquatic environments. Oll may persist for years. Cleaning of selt marshes by burning or cutting should be undertaken only if heavily olled. Mangroves should not be altered. Protection of these enviranments by booms or sorbent material should receive tirst priority. 
different oil compositions. In this model, the ten types of coastlines have been reduced to four: rocks, beaches, marshes, and man-made structures.

\section{Modeled Responses}

The first decision that the coordinator must make in the event of a spill is whether or not to respond to it. Spills which are small, quickly dispersed or evaporated, or blown out to sea generally do not require a response. The coordinator must be aware of the situation at all times as weather or equipment availability may interfere with decisions. In this model, if response is initiated, the coordinator may contain the spill, clean up the oil, clean up the shoreline, disperse the oil or any combination of these options.

In defining the response alternatives, each of the above options is associated with its own set of equipment. The nine equipment types modeled are: booms, vessels, sorbents, sorbent wringers, skimmers, barges, heavy construction equipment, dispersants and aircraft. Manual clean up of the shoreline and spray teams for cleaning rocks are also possible responses included in the program. Sources of information on equipment and their characteristics include reports, manuals, and advertisements. The largest source for pollution equipment locations and characteristics is the Coast Guard's SKIM program which was mentioned previously. The following sections describe the responses modeled within the program and describe the methodology used to develop the techniques. 
All of the equipment modeled share the common characteristics shown in Table 3-2. The first three pieces of information; location, number of units and owner, are normally listed in the SKIM data set. The response time includes the notification, setup, and travel times. The travel time is the time the equipment is in transit from the storage location to the spill site.

Equipment efficiency is a controversial topic so a review of existing data as well as assumptions which have been used in previous models is warranted. Evaluation of equipment in controlled environments such as the Environmental Protection Agency facility in New Jersey (Lichte 1979, Schwartz 1979) tend to be over optimistic when compared to real spills. Poor performance in the field is usually due to weather or high sea states, although it is sometimes caused by operator error or machinery breakdown. Cochran et al. (1975) and Holmes (1977) provide efficiency values for specific equipment based on sea state (see Figure 3-1). Blaikley et al. (1977) and Audunson et a . (1982) have designated overall "combat efficiencies." These values are estimates of the amount of oil cleaned up between the start of the spill and the time that it reaches shore. In reviewing reports dealing with real spills (Hess 1978, Marcoline 1980, O'Brien 1981), it was noted that these "combat efficiencies" are also too high. One of the systems rated to be most efficient, the Coast Guard's skimming barrier, is only rated fair in sea state 4 (US Coast Guard 1979). A set of efficiency classes have been 


\section{TABLE 3-2}

COMMON CHARACTERISTICS OF EQUIPMENT

Storage Location (Longitude and Latitude)

Number of Units Available

Owner 1. Government

2. Private Company

3. Spill Cooperative

4. 0 il Company or Facility

5. Contractor

Response Time

Preparation Time

Travel Time Land $33 \mathrm{mph}$

$\begin{array}{llr}\text { Sea } & \begin{array}{l}\text { Towing } \\ \text { Transit }\end{array} & 8 \mathrm{Kts} . \\ & 12 \mathrm{Kts} . \\ \text { Air Helicopter } & 100 \mathrm{kts} . \\ & \begin{array}{l}\text { Plane } \\ 130 \mathrm{Kts}\end{array}\end{array}$

Efficiency For Skimmers, Booms, and Wringers 
defined by the author and are shown in Figure 3-1. These new values decrease the rated efficiencies to include equipment breakdown or any other problems which may be encountered. These classes are used for booms, skimmers and absorbent wringers.

The responses described below are based on actual responses and the equipment modeled has characteristics similar to actual gear. Unless specifically stated, the modelled parameters are exactly the same as actual data. Some generalizations of equipment characteristics are made to ease computation. The following section will describe the equipment characteristics and the methods used to model the responses.

\section{Containment}

One of the first responses normally put into action during spills is containment or protection so it will be the first section of the program to be discussed. This modeled response makes use of booms to enclose the oil and keep it from spreading or to deflect the oil away from vulnerable areas. The boom characteristics in Table 3-3 are loosely based on the U.S. Navy system which defines 3 classes of booms having 8 inch, 16 inch, and 24 inch drafts respectively. Additional characteristics come from Bellantoni (1979), Byroade (1981), Foget (1979), and SKIM. There are no actual booms with a draft of 60 inches as in class 5 . This choice has been included to model attempts to block a narrow breachway or harbor entrance by dumping sand into it, effectively. stopping almost any oil from entering the protected area. 


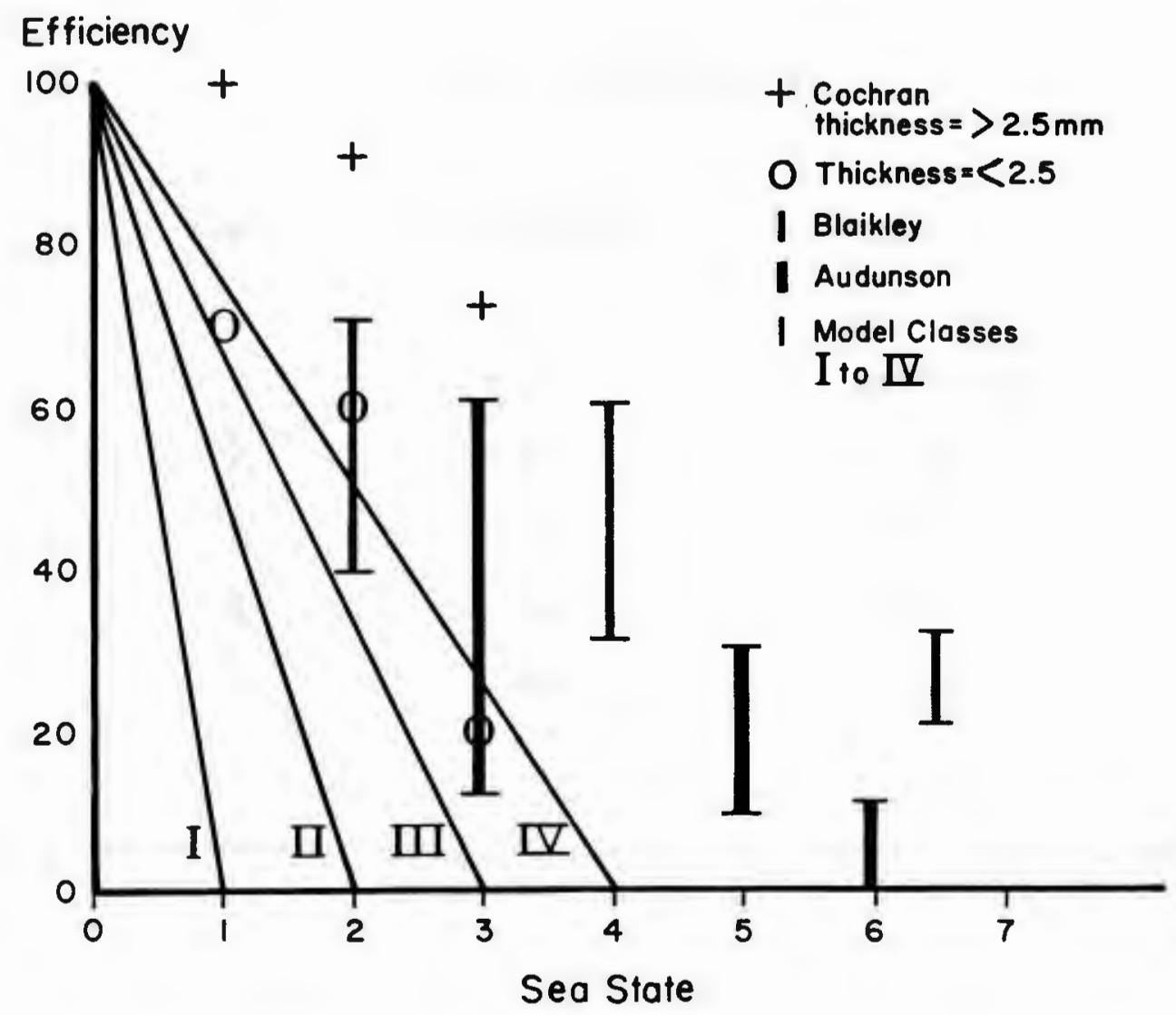

Figure 3-1 Cleanup Efficiencies 


\section{TABLE 3-3}

BOOM CHARACTERISTIC

$\begin{array}{ccc}\text { Class } & \text { Draft (in) } & \text { Cost } \\ 1 & 6 & \$ 1 / \mathrm{ft} . / \text { day } \\ 2 & 12 & 1.25 \\ 3 & 24 & 2.00 \\ 4 & 36 & 2.00 \\ 5 & 60 & 3.00\end{array}$


The deployment of booms during a spill requires vessels of one type or another. In this model, the vessel characteristics shown in Table 3-4 were taken from SKIM, Byroade (1981) and the Argo Merchant report (1978). The smaller vessels are in general used nearshore while the larger ones are used offshore. These vessels are utilized in other response alternatives as well.

The boom itself is modeled after Swanson and Spaulding (1980) who combined research from Cross and Hoult (1971) and Abrahams (1977). In this model, the trajectory of the center of the surface spillet must pass between the end points of the boom otherwise the oil is not contained. After the oil is inside the boom, there are two methods by which it can leave, assuming that the current direction does not change. First, if high currents are present, oil can be entrained into the water column, so particles are created based on the loss values of Abrahams (1977). Second, the amount of oil which the boom can hold is limited by the efficiencies described before in Figure 3-1. Higher sea states can cause a pumping action which allows some oil to go over or under the boom. If this occurs the program creates another surface spillet on the far side. A more detailed description of this algorithm is contained in Appendix $B$.

When activating a containment response, the user supplies inputs include the boom end locations, the classes of the boom and vessels. One veșsel is deployed for every 200 meters of boom and all equipment is deployed until the user retrieves it. 


\section{TABLE 3-4}

\section{VESSEL CHARACTERISTICS}

$\begin{array}{lll}\text { Class } & \text { Length } & \text { Cost } \\ & \\ 1 & >30 \mathrm{ft} . & \\ 2 & <30 \mathrm{ft} . & \$ 150-350 / \text { day } \\ 2400-2400\end{array}$


Cleanup

For cleanup on water during a spill, skimmers and absorbents can be deployed by the user to pick up the oil and remove it from the area. In this program, methods utilize several different types of equipment and several classes of skimmers and absorbents.

Absorbents from various manufacturers come in a wide variety of types, weights, and materials and the general parameters used in this model are listed in Table 3-5. These values are taken from Foget et al. (1979), Beach (1978) and manufacturers literature such as the National Conventioneer (1979). The cost ranges from $\$ 0.30$ to $\$ 4.00$ per pound. The pickup ratios, which are the amounts of oil picked up per pound of absorbent material, depend on the type of absorbent, the material of which it is constructed and the weight of the oil. Pickup ratios vary from four for straw to a ratio of nineteen for some newer materials when heavy oil is retrieved in this model.

Absorbent booms are constructed of the same type materials as absorbents but are 6 to 10 feet long and weigh 10-20 pounds. Each section costs between $\$ 40$ and $\$ 60$. The pickup ratio can vary, although for this study a value higher than the other absorbents is used. This value of 20 assumes that the booms are thoroughly saturated before being 


\section{TABLE 3-5}

\section{ABSORBENT CHARACTERISTICS}

$\begin{array}{clcc}\text { Class } & \text { Type } & \text { Weight (lb.) } & \text { Cost } \\ 1 & \text { P1llows } & 3 & \$ 10 \\ 2 & \text { Rolls } & 30 & \$ 125 \\ 3 & \text { Bales } & 50 & \$ 200 \\ 4 & \text { Sheets } & 1-10 & \$ 4-25 \\ 5 & \text { Bags } & 10-25 & \$ 12-60 \\ 6 & \text { Straw } & 30 & \$ 5\end{array}$


recovered. The booms have a diameter of 6 to 9 inches and can normally stop oil movement in very low currents. In order to reduce computations, the absorbent booms used in this model do not affect. 011 movement.

Another method for 011 pickup during spills is sorbent wringers. These use an absorbent belt on a pulley system with a wringer at one end to squeeze out the recovered oil. The characteristics can vary greatly among manufacturers. The characteristics used in this model, in Table 3-6, are based on literature from $011 \mathrm{mop}$ Inc.

A normal absorbent deployment in this program involves one type of absorbent and vessels if requested by the user. After entering the approximate position of the oil location, the effort is initiated and up to one-half of a metric ton is cleaned up from the closest spillet every 30 minutes. The efficiency of the wringers are taken from Figure $3-1$. They remain deployed until retrieved by the user.

The other method available to the user for cleanup on water is the use of skimmers whose characteristics are in Table 3-7. These are taken from SKIM, Foget (1979), Beach (1978), and Schwartz (1979). The classes are based on U.S. Navy classifications and the efficiencies are those shown in $\mathrm{Fig} .3-1$.

A method of storage is included for the skimmer's use. When skimmers are being used near the coast, a tank truck is assigned by the 


\section{IABLE 3-6}

WRINGER CHARACTERISTICS

$\begin{array}{ccc}\text { Class } & \text { Rate (gal./hr.) } & \text { Cost/day } \\ 1 & 210 & \$ 50 \\ 2 & 336 & \$ 300 \\ 3 & 588 & \$ 400 \\ 4 & 3750 & \$ 550\end{array}$




\section{TABLE 3-7}

SKIMMER CHARACTERISTICS

$\begin{array}{lcc}\text { Class } & \text { Work Rate }(g a 1 . / h r .) & \text { Cost/day } \\ 1 & 25 & \$ 100 \\ 2 & 200 & \$ 400 \\ 3 & 700 & \$ 650 \\ 4 & 1000 & \$ 1000\end{array}$


model. The characteristics of the trucks are capacity (2500-6000 gallons) and cost per hour $(\$ 40-\$ 75)$ and are taken from SKIM and Byroade (1981). For offshore spills, floating storage is deployed. In the field, the two types of containers are steel barges which range from 1150 to 150,000 gallons capacity and flexible rubber bladders which can hold 50 to 6400 gallons. The characteristics in Table 3-8 cover this range and are taken from Allen (1982), SKIM and Bellantoni (1979). The cost includes a tug at $\$ 100$ per hour.

When initiating a skimmer response, the desired position is entered and the effort operates on the closest surface spillet as the absorbent efforts did. Vessels and booms can also be deployed with a response. When a boom is used with a skimmer, it is assumed that the boom collects the oil thus increasing the skimmer efficiency but not inhibiting the movement of the oil. The user must discontinue this response when cleanup is completed.

Cleanup on shore

Shoreline cleanup requires different types of equipment and techniques which are dependent upon weather, oil composition, and shoreline type. In his manual for on-scene coordinators, Byroade (1981) has detailed 23 methods which use various types and combinations of personnel and equipment. The options which Byroade has described have been reduced for this program and configured such that one cleanup 


\section{TABLE 3-8}

BARGE CHARACTERISTICS

$\begin{array}{crc}\text { Class } & \text { Capacity (gal.) } & \text { Cost/hr. } \\ 1 & 150,000 & \$ 500 \\ 2 & 50,000 & \$ 300 \\ 3 & 2000 & \$ 250 \\ 4 & 50 & \$ 100\end{array}$


technique has been modeled for each type of shoreline and cannot be used on other types.

The normal procedure suggested by Byroade to clean up beaches is to use heavy construction equipment. Premack (1975) and Byroade (1981) supply the cost of equipment (see Table 3-9) and Byroade calculates the workrate of several combinations of equipment. This rate varies from .01 to .165 hectare $(10,000$ square meters) per hour per piece of equipment and the averages are shown in Table 3-9. No work is performed on the beach unless the mass density is greater than .l tons per kilometer of shoreline.

Spray teams can be deployed in this program to clean rocks and man-made structures. They can clean fifty square meters per hour and cost $\$ 30$ an hour (Byroade 1981). Normally, the oil/water mixture which flows off the rocks runs into trenches or a boom where a skimmer or pump removes it, but this additional operation is not included in this program.

Byroade suggests that manual cleanup be performed if the spill occurs in vulnerable areas such as marshes because of the potential damage which can be done by heavy equipment or high pressure hoses. Personnel can cut away damaged vegetation at a rate of 65 square meters per day (Byroade 1981). This cleanup rate may be too high if small patches of oil need to be shoveled out but it is used here due to lack of a better estimate. Personnel costs range from $\$ 13$ to $\$ 50$ per hour. The higher values represent supervisors and foreman who comprise a smaller percentage of the 


\section{TABLE 3-9}

\section{HEAVY CONSTRUCTION EQUIPMENT}

$\begin{array}{llccl}\text { Class } & \text { Type } & \text { Cost/hr. } & \text { Cost Fuel/hr. } & \begin{array}{l}\text { Workrate } \\ \text { (Hectare/hr.) }\end{array} \\ 1 & \text { Frontend loader } & \$ 25 & \$ 12 & .06 \\ 2 & \text { Bulldozer } & 25 & 12 & .03 \\ 3 & \text { Grader } & 25 & 12 & .1 \\ 4 & \text { Backhoe } & 25 & 12 & .02\end{array}$


workforce so a cost of $\$ 20$ per hour, near the lower end of the range, is used. Again, the final step in the cleanup, removal of the debris from the area, is not included in this program.

When initiating a cleanup response, the user inputs a location and decides which equipment and personnel are to be deployed. The response will then clean any ofled shore within a 1000 meter radius. Calculations are performed which assumes that the oil is dispersed over a ten meter width of beach. This is considered an average value since marshes will have larger areas and man-made structures a smaller value. The amount of oil on the shore is reduced by the fraction of area which an effort can cover. The user must terminate the response when cleanup is no longer needed.

Dispersants

One response which sees 1 imited use in the field is the deployment of dispersants. Dispersants are chemicals which break up the oil. This causes the oil to enter the water column so there are strict regulations in force governing their use in shallow coastal waters. The capability of dispersants has been included in this model for research purposes.

The use of dispersants require the chemical, usually in liquid form, and a deployment platform, usually a vessel or aircraft. The cost of the dispersant varies from $\$ 2$ to $\$ 8$ per liter with their efficiency a function 
of method of application, the weather and oil properties. The methods of application and accompanying parameters are discussed below.

Deployment platforms for dispersing are vessels, helicopters and fixed wing aircraft and their dispersant operation parameters for this model are listed in Table 3-10. These are average values taken from Beach (1978). Allen (1982) and McAuliffe et al. (1979). The volumes are fixed by capacities and the distribution and rates are based on average speeds of the aircraft and vessels. The vessel characteristics. were discussed in the section describing containment and the aircraft characteristics are shown in Table 3-11. The vessels take 12-13 hours to apply the dispersant on the oil and the aircraft can perform this job in less than 30 minutes. Efficiency data were collected by McAuliffe et al. (1979) during tests of Southern California and the values used in the model are based on this research. The efficiency of dispersants depends on the weather and the time after the spill when it is applied. The first set of efficiencies in Table 3-10 are average values for newly spilled oil and the others are for weathered oil.

For a dispersant effort, the user inputs the approximate location and selects the delivery platform to be used (vessel, helicopter, or airplane). This selection results in the assignment of the remaining values. The closest surface spillet or a fraction of the spillet is then treated until the amount of dispersant is depleted. 


\section{TABLE 3-10}

\section{DISPERSANT OPERATION PROPERTIES}

Helicopter Plane Vessel

$\begin{array}{llll}\text { Volume (liters) } & 150 & 600 & 1000 \\ \text { Distribution (1iter } / \mathrm{m}^{2} \text { ) } & .005 & .005 & .004 \\ \text { Rate (1iter/hr.) } & 300 & 200 & 75 \\ \text { Efficiency (percent) } & 30 & 40 & 50 \\ \text { Efficiency (after 2 hrs) } & 21 & 28 & 35\end{array}$




\section{TABLE 3-11}

\section{AIRCRAFT CHARACTERISTICS}

\section{Type}

Plane

Helicopter
Cost

$\$ 300 / \mathrm{hr}$

400 


\section{Spill Impact and Costs}

The next step performed by the program is to determine the impact of an oil spill on a region. There are many aspects which influence the intensity of an impact. Large spills with heavy types of oil cause serious effects especially if long sections of vulnerable coastlines or critical areas are affected. The result could be an increased mortality rate for animals which may reside in a particular location during certain times of the year, either on land, in the water column, or on the sea floor. Sea state, currents and weather can change the effect by moving the oil toward or away from an area or by changing the effectiveness of a response technique. The method used to determine impact in this model is presented below.

Many people have attempted to quantify impact, although most research is directed towards the economic effect on a region. The most extensive work has been on the impact of the Amoco Cadiz (Auguier 1982, Hess 1978, Meade 1982). Recently the Massachusetts Institute of Technology has developed a model which attempts to addresses all aspects of spill impact (Nyhart et al. 1981, 0il spill Clean Up 1981). Both of these studies are too specific and contain too many variables, so a generic method is needed which can be used for any type of location or spill. 
Schulze's (1981) recommendation was to find common denominators and his measure of impact is the product of the volume of the spill, the sensitivity and the area of the region affected. A high value indicates a large impact and results can be compared at times of interest or summed over the length of the spill. This will permit comparison of various responses for the same spill. Schulze's work has been modified for thisresearch. The volume of the spill has been removed as a parameter because the user has no control over it. The area affected and the sensitivity of that region are then the main parameters and these factors are calculated for the surface $0 i 1$, the subsurface 011 , and the oil on the shoreline.

The amount of area affected is first determined. For the surface oil, the area covered by individual spillets is calculated. No correction is made for overlapping areas which may result in overestimates of area for closely spaced spillets. The calculation of the area affected by subsurface oil is more complicated. Subsurface droplets are tracked with respect to a rectangular expanding grid which is three-dimensional and the concentration is calculated at each grid point. For impact calculations, vertical sections are averaged and the result is a two-dimensional horizontal grid of concentrations. If the concentration of these vertically averaged sections exceeds a user defined value, the area which is covered by that section is summed. The minimum concentration chosen is a function of the resistance to $0 i 1$ of the organisms in the area. Some nominal values for the mortality as a 
function of oil concentration are shown in Table 3-12. Reed (1980) used a concentration of $50 \mathrm{ppm}$ for fish studies in Georges Bank.

The amount of oil on the shoreline can vary and the program calculates impact based on a minimum shoreline density. After the Amoco Cadiz, researchers found oil in the coastline soil with densities of 5 to 50 tons per kilometer at thicknesses ranging from 4 to 100 millimeters (Hess 1978). For this research, an average width of 10 meters is assumed to be affected and a minimum threshold value of .5 tons per kilometer is used. The threshold can be changed by the user in the plotting programs at the end of the main program.

The sensitivity to a spill is defined as the combined ecological and social impact on the area. Each region is assigned a weighting factor which is somewhat arbitrary, but can be changed in the program depending upon the research being performed. At this time, the subsurface is taken to be twice as sensitive as the surface and the shoreline region is three times as sensitive. Each of the shoreline types have been assigned a value. Rocky and man-made coasts are assigned a weight of one, beaches a weight of one and one-half and marshes a weight of two. This system results in the marshes receiving six times the weight in calculating impact as the surface. 
Table 3-12 (Malins 1977)

Acute toxicity of petroleun to marine animals.

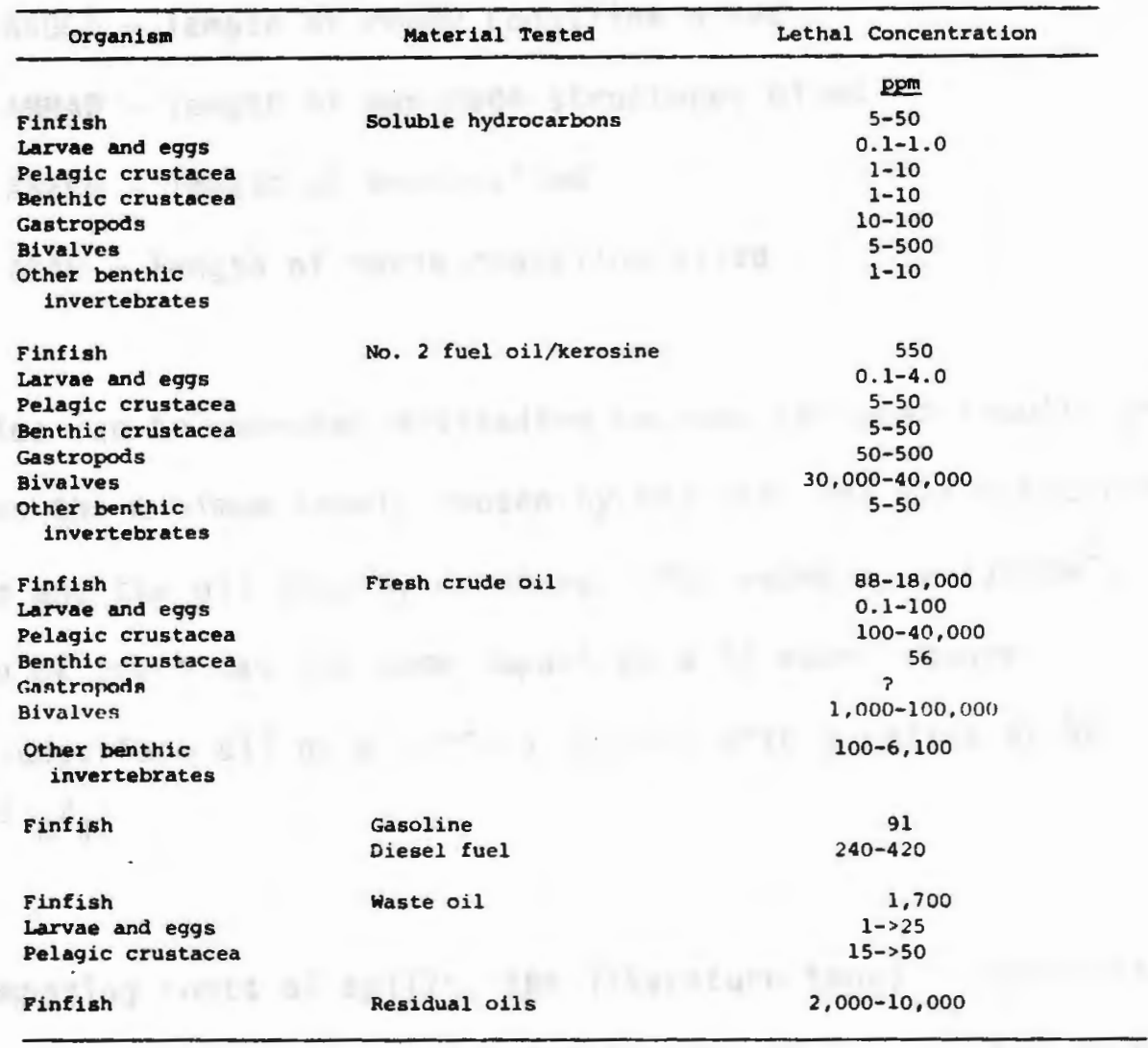


The complete equation for impact is shown below:

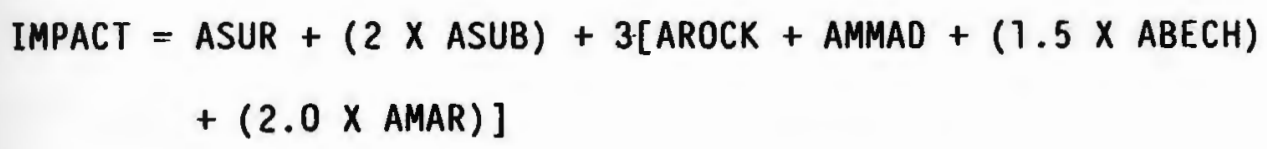

Where: ASUR - area covered by surface oil

ASUB - extent of subsurface oil

AROCK - length of rocky coastline oiled

AMMAD - length of man-made structures oiled

ABECH - length of beach oiled

AMAR - length of marsh coastline oiled

The final value can be somewhat misleading because the area results are dependent upon the minimum levels chosen by the user for the subsurface concentration and the oil density on shore. For example, a $\left(3330 \mathrm{~m}^{2}\right)$ meter section of beach has the same impact as a 70 meter square $\left(4900 \mathrm{~m}^{2}\right)$ of subsurface oil or a surface spillet with a radius of 56 meters $\left(\pi \times 56^{2} \mathrm{~m}^{2}\right)$.

When comparing costs of spills, the literature tends to normalize the amount by determining the money spent per ton of oil spilled or ton of oil cleaned up. The values in Table 3-13 reflect actual spills as well as modeled spills. Normally, the cost of a spill is greatly increased when the oil is washed ashore. The shoreline was heavely oiled during the Tamano and Amoco Cadiz spills so the costs associated with the 


\section{TABLE 3-13}

OIL SPILL COSTS (1984 Dollars)

ARGO MERCHANT

TAMANO

AMOCO CADIZ

FRANKLIN

HOLMES

LITTLE
$\$ \quad 110$ per ton spilled

$\$ 28,000$ per ton spilled

$\$ 81,500$ per ton spilled

$\$ 246,000$ per ton cleaned up

$\$ 163-\$ 530$ per ton cleaned up

$\$ 21-\$ 116$ per ton cleaned up of fshore

$\$ 59-\$ 62$ per ton cleaned up inshore

\$16-\$326 per ton cleaned up on shore

$\$ 3573$ per ton spilled 


\section{TABLE $3-13$}

OIL SPILL COSTS (1984 Dollars)

ARGO MERCHANT

TAMANO

AMOCO CADIZ

FRANKLIN

HOLMES

LITTLE
$\$ \quad 110$ per ton spilled

$\$ 28,000$ per ton spilled

$\$ 81,500$ per ton spilled

$\$ 246,000$ per ton cleaned up

$\$ 163-\$ 530$ per ton cleaned up

$\$ 21-\$ 116$ per ton cleaned up of fshore

$\$ 59-\$ 62$ per ton cleaned up inshore

$\$ 16-\$ 326$ per ton cleaned up on shore

$\$ 3573$ per ton spilled 
responses are much higher than the others values in the table. The cost of the response per ton spilled may be more applicable because, as in the case of the Argo Merchant, oil is not always cleaned up.

This program allows a user to run a specific spill and then rerun it using various response techniques. Since not every possible response and equipment is modeled in this program, the impacts and costs may not compare to actual data. The relative impacts and costs of various responses can be compared to determine which methods are more effective. The user will learn the appropriate questions and problems associated with the various methods and can implement this knowledge during actual spills.

\section{Model Integration}

There were two steps performed for model integration after the detailed routines were developed. The first was to combine all of the modeled processes, responses and evaluation methods into a workable interactive model. Then, programs which handle all aspects of input and output data were developed. During both steps, the algorithms were designed to allow easy use of the program and to allow as much flexibility as possible. This results in three sets of programs: 1) a group for manipulating and plotting input data for the main program; 2) a ma in section containing the routines, for modeled processes and responses 
and; 3) programs which process and plot the output results from the main program. The main program's framework will be discussed below followed by an explanation of the input and output programs and the resulting graphics.

The main simulation is set up in sections so that for each time step, the model handles, under user control, implementation of the theoretical routines. When the user initializes the model, the program offers two major options. If the subsurface portion of the oil is not considered to be important for a run, the program will allow an abbreviated run which does not create subsurface particles and track them. All other processes are included and the mass balance still includes subsurface oil. This alternative is preferred for simple trajectory studies as it is substantially faster. An option is also offered regarding input data. At each time step, a user can change any value of the environmental input. This option provides flexibility during a research or trajectory study by allowing use of data which is not avallable. One example of this is to have the wind blow from a specific direction for a certain length of time. For training runs, this option is not desireable.

During a run the user is continually queried by the program regarding the information she/he might like to see and the action to be taken. For example, the location of surface oil is displayed by a map of the spill area at the user's request. Figure 3-2 shows such a map. 
Figure 3-2 Sample of Interactive Map

12.8 HOURS FFTER STRRT OF THE EPILL

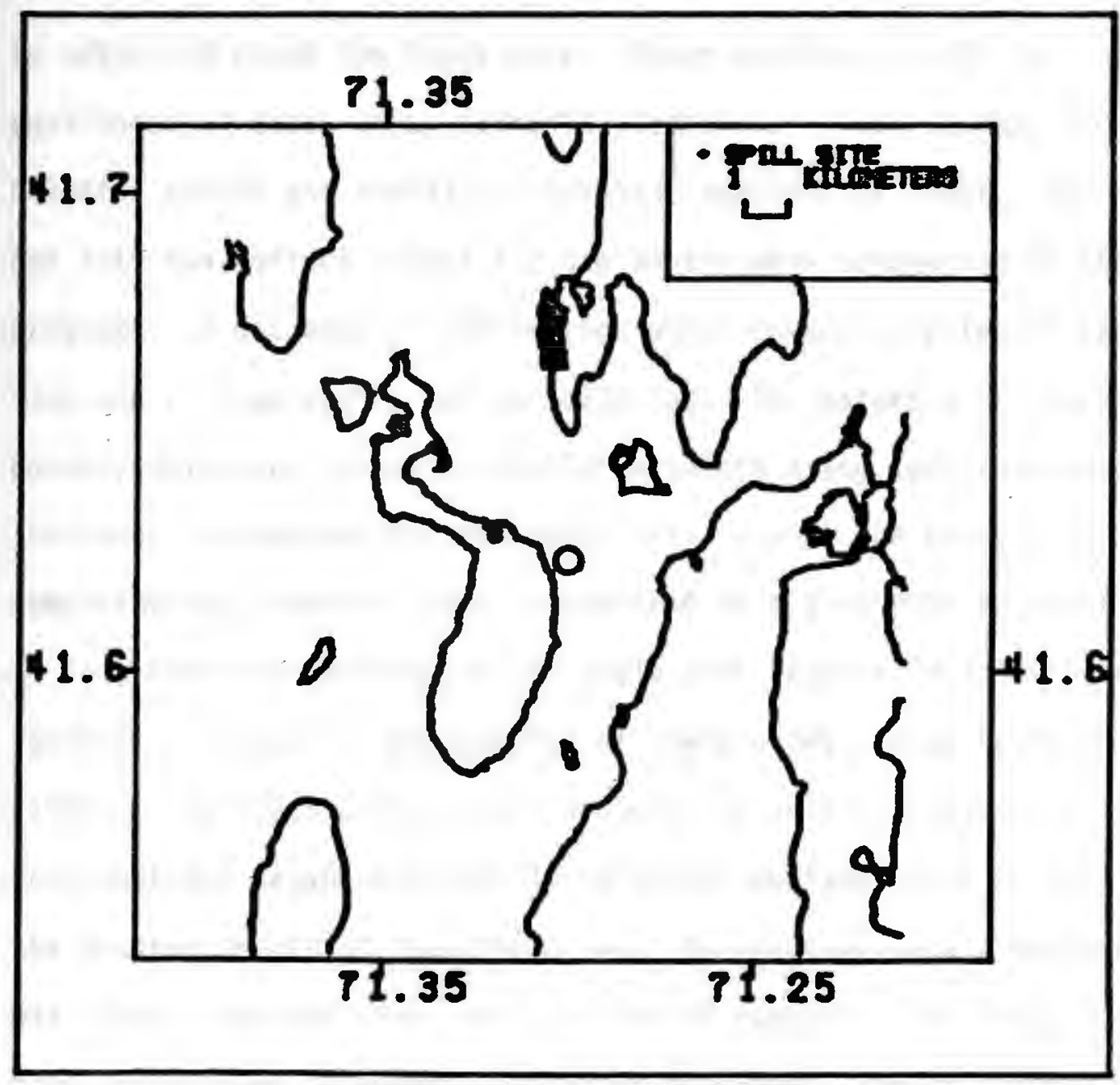


Other information which can be supplied by the model at the user's request includes updates of equipment deployment, in Figure 3-3, current costs. Figure 3-4 and the impact of the spill. Figure 3-5. Predicted wind and sea states in a format typically seen by an on-scene coordinator, can also be listed if the user desires.

The next phase of model integration was the development of programs to setup and check the input data. These programs handle the environmental data; wind, currents, temperature, sea states, tidal heights, depths and shoreline location, required as input. The data are put into the correct format for use in the main simulation by these programs. A database of information which covers an extended period of time and a large region can be collected. The database of shoreline points, which are stored as digitized points using longitude and latitude, is searched to find those which are in the study are. The remaining environmental data are defined by a grid with a specific origin in longitude and latitude and an angle with respect to lines of constant latitude. A detailed explanation of these grids can be found in [Wilson] (1980). The input programs are designed to select a portion of the environmental database by utilizing spill location, time of spill, and the desired length of the simulation. By choosing only a portion of the data base, computer time and space can be reduced. The input data can then be reviewed by numerous plotting programs. The study area and shoreline can be examined by plots such as Figure $3-6$. This map can be expanded to include shoreline types, boat launch facilities and access 
Figure 3-3 Typical Display Concerning Responses

SKIMMING CAN BE DOME FROM SHORE OR DEOICATED UNITS

OD YOU HANT TO INITIATE A SKIMNER RESPONSE?

DO YOU WANT TO DEPLOY A SKIMMER?

DO YOU WANT A SKIMMER/HRINGER STATUS REPORT?

YES

THE 1 SKIMMER IS OPERATING AT $71.51 \mathrm{~W}$ AND $41.342 \mathrm{~N}$

II IS A 1 CLASS SKIMMER AMD IS HORKING AT

IT HAS 2 BOATS

IT HAS 1 TRUCKS

DO YOU WANT TO STOP A SKIMMER OR HRINGER RESPONSE?

CLEANUP ON SHORE IMCLUDES

SPRAY ING, HEAUY EQUIPMENT AND MANUAL CLEANUP

DO YOU HANT TO START UP ONE OF THESE?

DO YOU HANT TO INITIATE A RESPONSE?

DO YOU HANT A SHORE CLEANUP STATUS REPORT?

YES

THE 1 EFFORT IS AT 71.67 H AND $41.35 \mathrm{~N}$

IT STARTS AT TIME 2 PIECES OF EQUIPHENT

IT HAS 20 CLEANUP PERSONHEL

IT HAS 2 SPRAY TEAMS

\section{Figure 3-4 Typical Display Showing Costs}

THE COSTS AT TIME CONTAINMENT

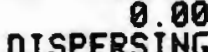
R.QE SKIMFING 3106.00 ABSORPTION SHORE 9.80 BOATS CLEANUP
B. 2900.00 TOTAL

$$
\begin{aligned}
& \text { COST MAETRIC COST/METRIC } \\
& \text { TON SPILLED TON CLEANEDO UP } \\
& 62.80
\end{aligned}
$$

0.38 TONS/MINUTE 
THE AREA COUERED BY SURFACE OIL AND SUBSURFACE ARE
THERE ARE
0.55
0.26 KILOMETERS OF BEACH
Q.80 Square kILOMETERS
THE IMPACT OF THE SURFACE OIL AND SUBSURFACE OIL ARE
6. 60 KILOMETERS OF ROCKS
0.08 KILOMETERS OF MAM=MADE

THE SHORELINE IMPACT ${ }^{\circ}$ IS

RESULTING IN A IMPACT THIS STEP O 0.12

TOTAL IAPACT OF SPILL IS 25.86

0.08

$?$

Figure 3-5 Typical Display Showing Impact

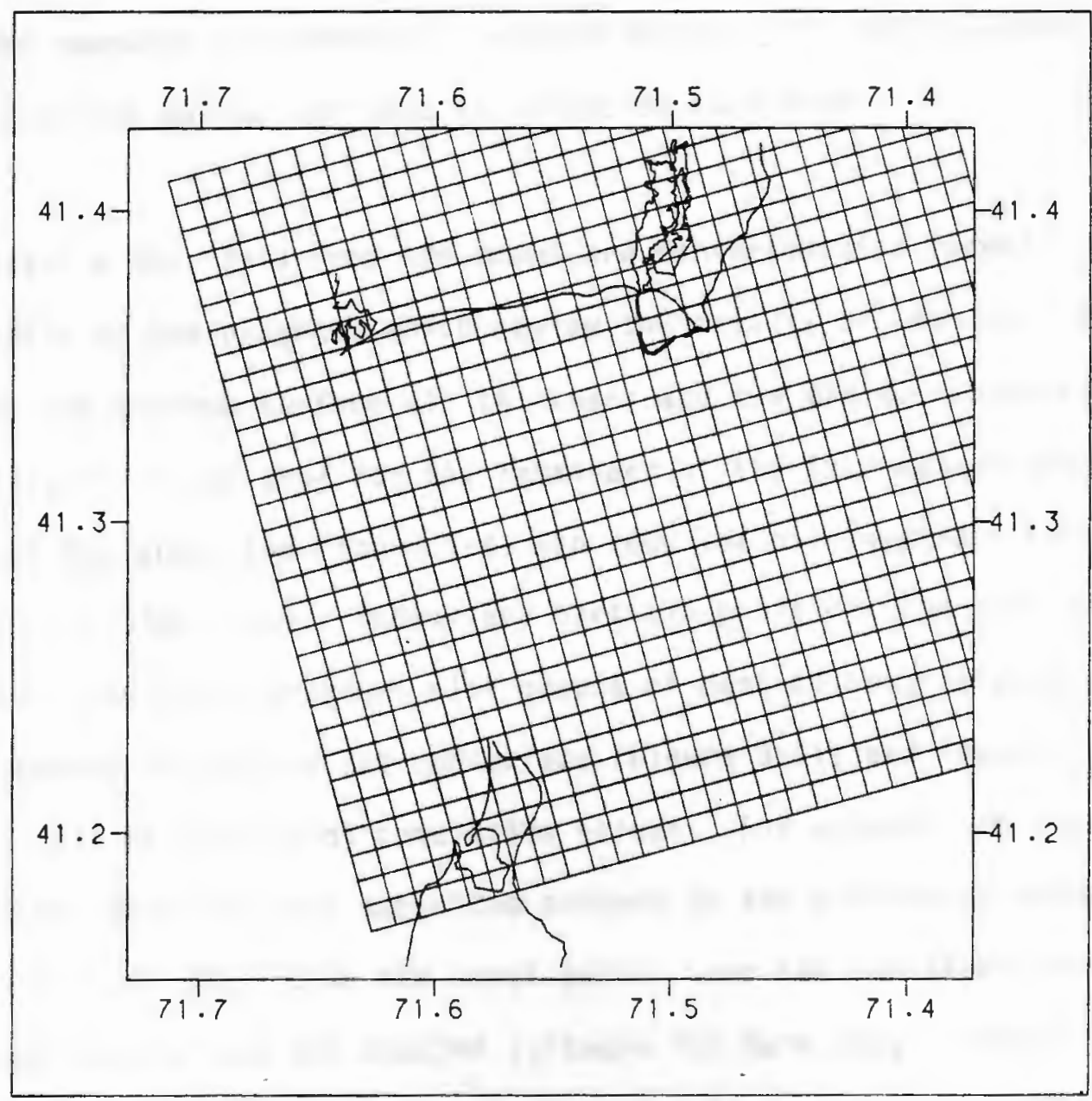

Figure 3-6 Plot of Grid System 
points. Other graphs such as wind speed and direction can be generated (see Figure $3-7$ ) and maps showing currents can be displayed as in Figure 3-8. These plots can be displayed interactively or on a plotter using CALCOMP plotting routines.

Other data needed as input to the program and not manipulated by any of the input programs are the locations and characteristics of response equipment. The type of data needed and references to it were explained in the previous sections of this chapter. This data is stored on a separate computer file which is typed in manually by the programmer, not to be accessed by the user and is unique to each area.

After a run, data from the model are converted to a format acceptable by the programs which review the results of the run. The user defines the minimum surface oil thickness and the minimum subsurface concentration to be used for the remainder of the four output programs. A map of the area (see Figure 3-9) can show the oil locations for any multiple of time steps. Subsurface particle positions can also be plotted. The final programs plot graphs of mass balance (Figure $3-10$ ), areal extent of surface and subsurface (Figure $3-11$ ) and impact (Figure 3-12). All of these plot cumulative values. For example, in Figure $3-10$, the amount of mass deposited onshore is the difference between curves one and six. Like the input plots, user can run these programs interactively or use the CALCOMP software for hard copy. After a simulation, these programs can be used many times with changes in the 


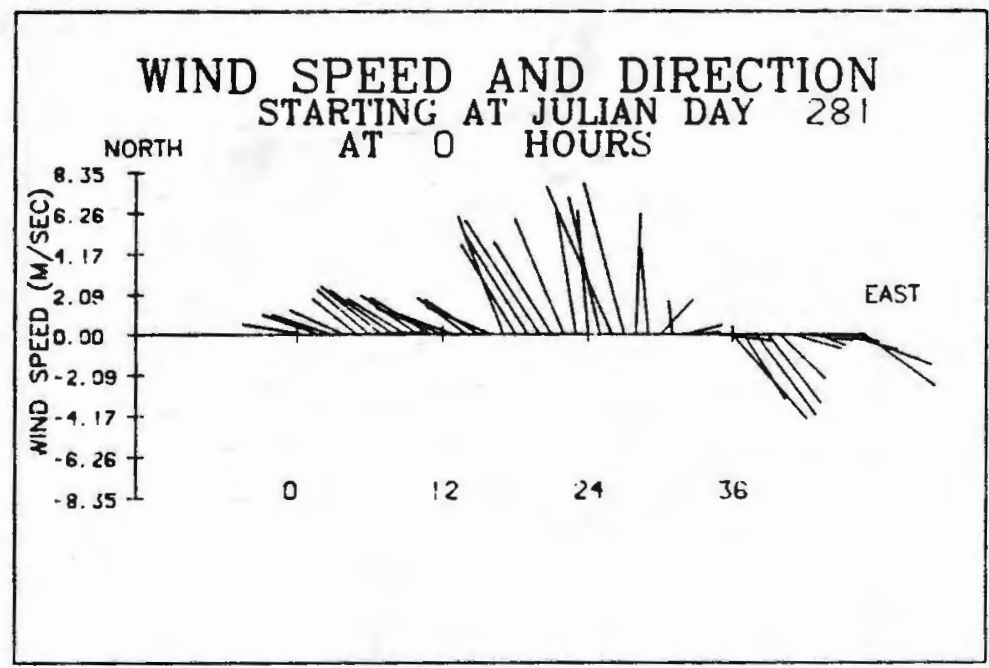

Figure 3-7 Plot of Wind Data 


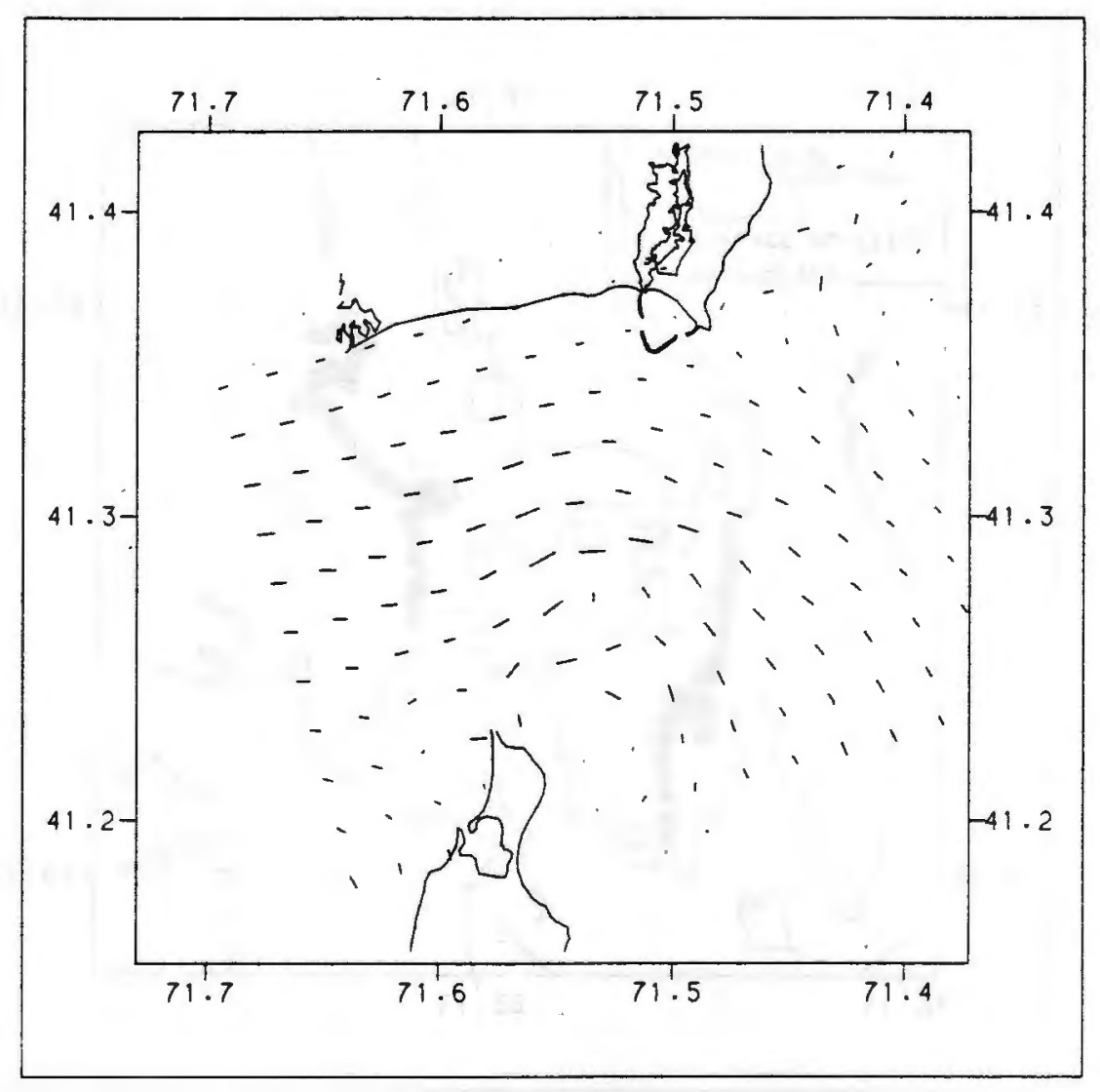

Figure 3-8 Plot of Current Data 
71.0 HOURS AFTER START OF THE SPILL MAP OF SPILLETS AND SUBSURFACE

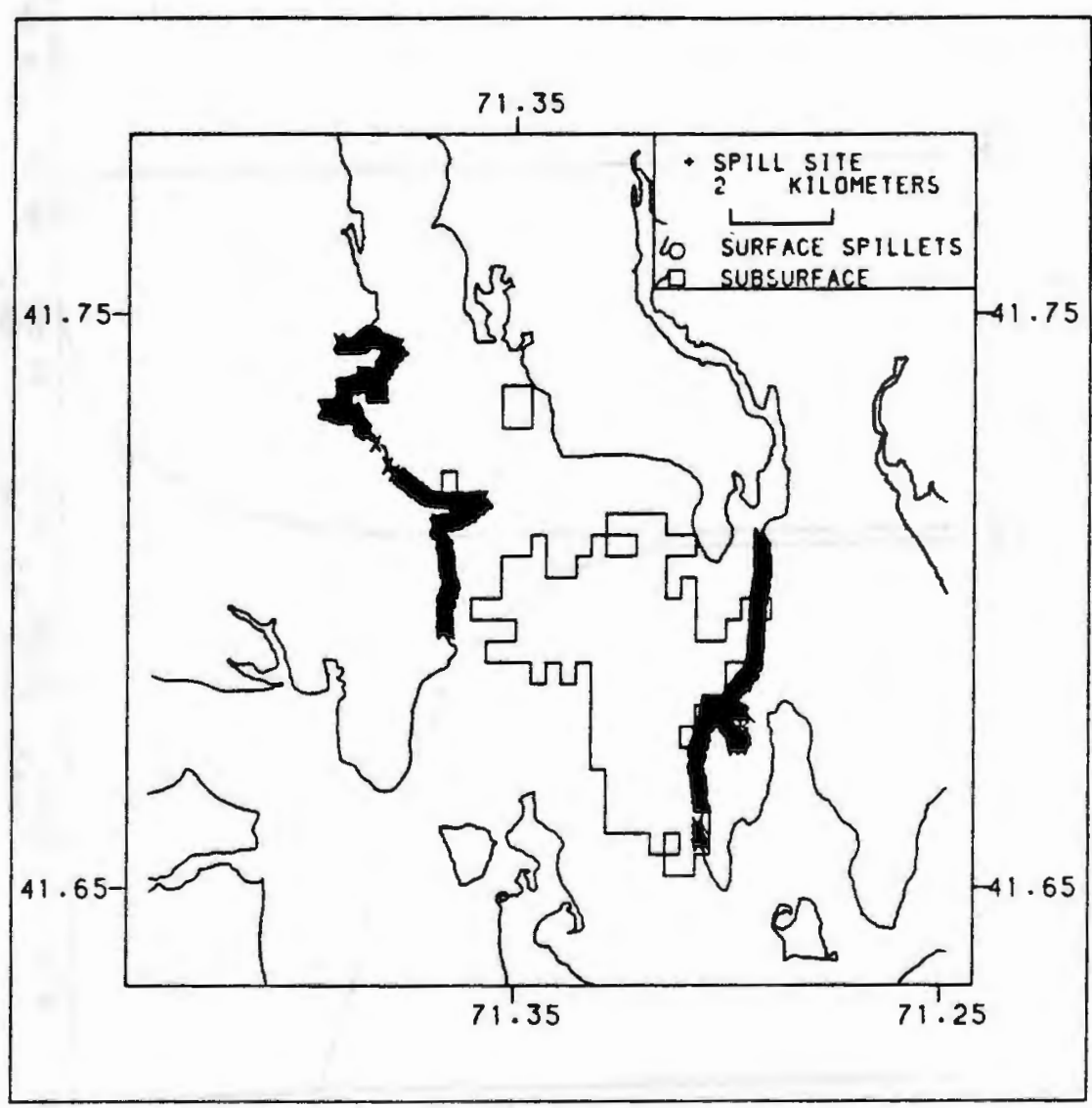

Figure 3-9 Plot of 0 il Locations 


\section{MASS DISTRIBUTION}

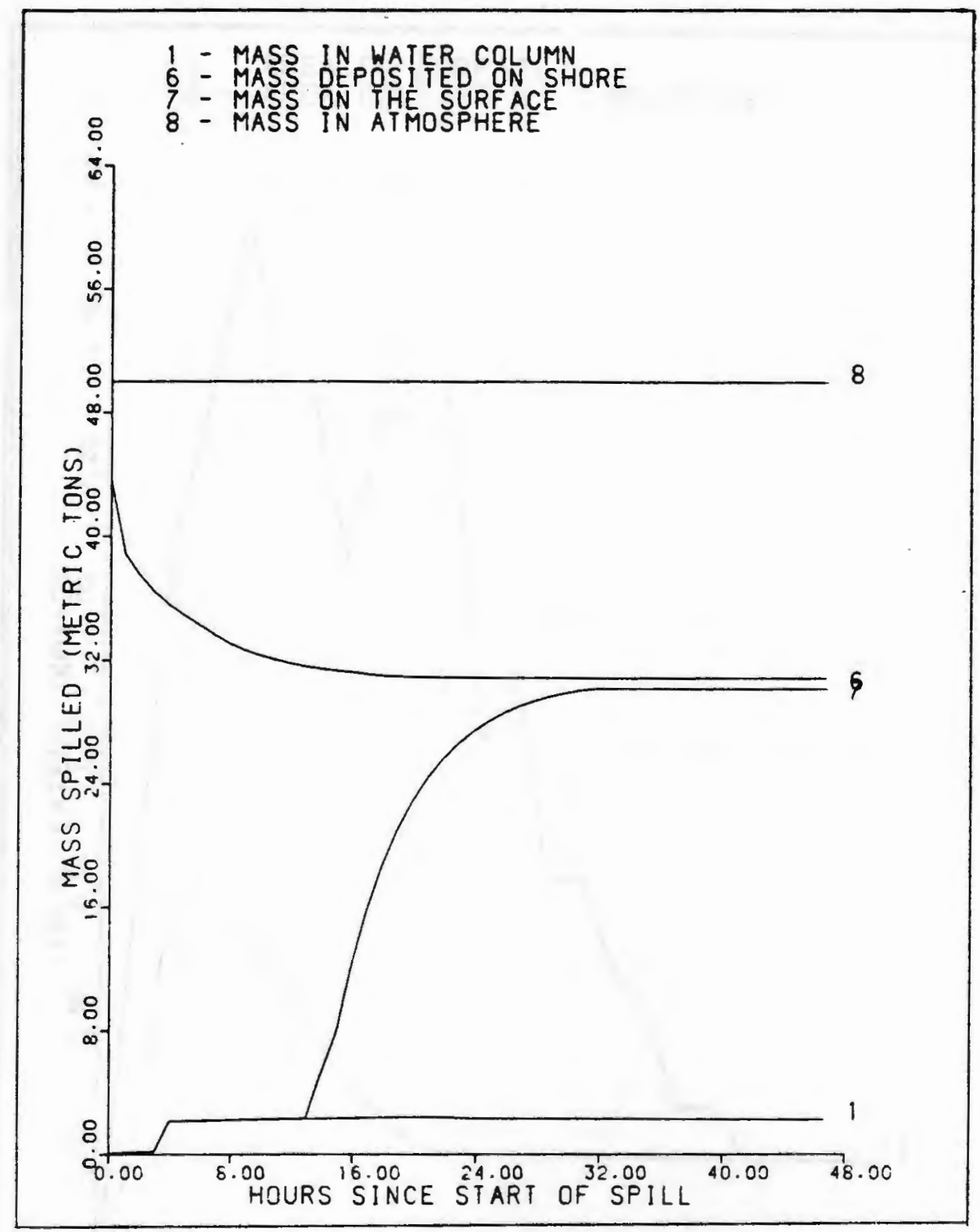

Figure 3-10 Plot of Mass Distribution 
AREA COVERED BY SPILL

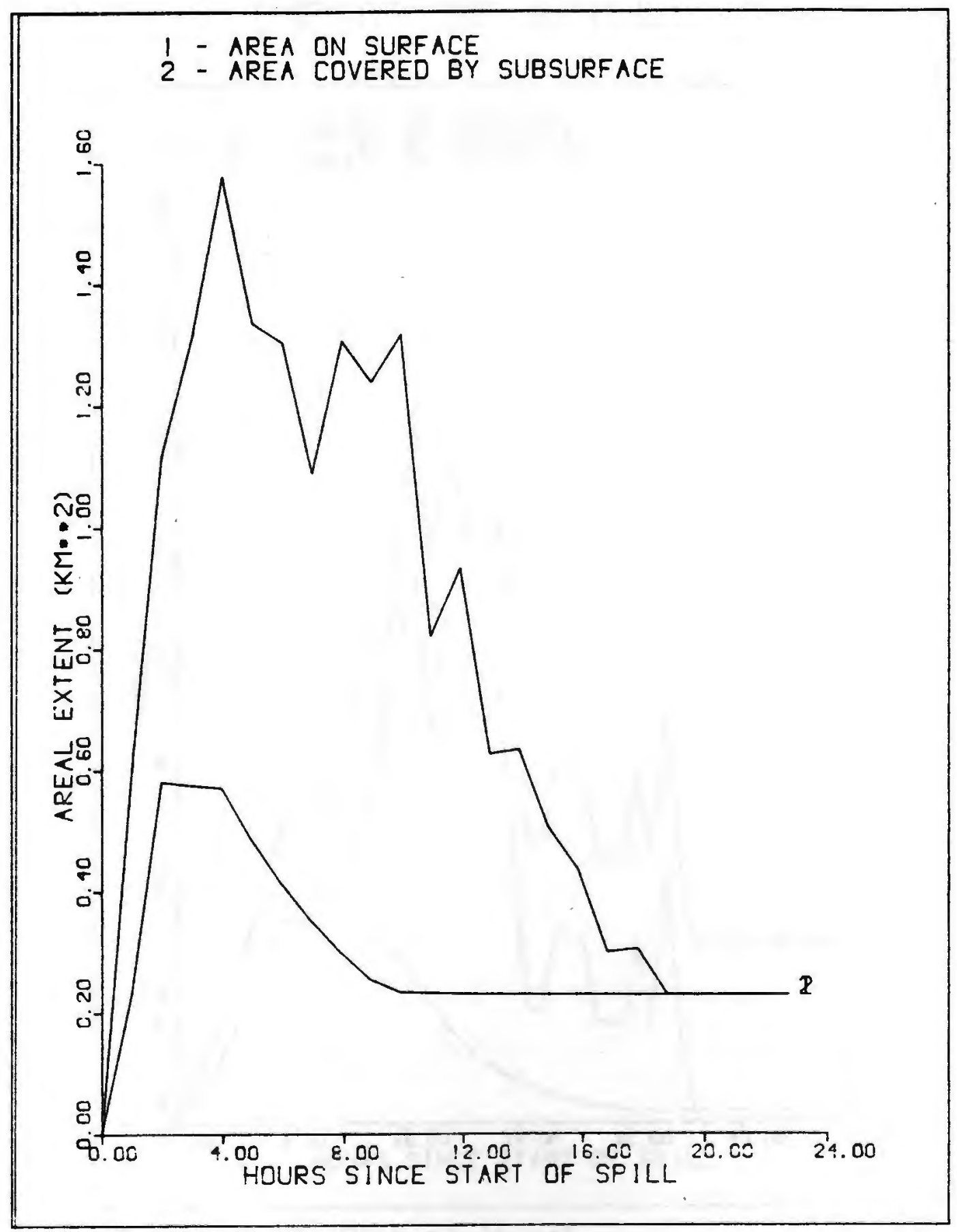

Figure 3-11 Plot of Areal Coverage 
IMPACT OF SPILL

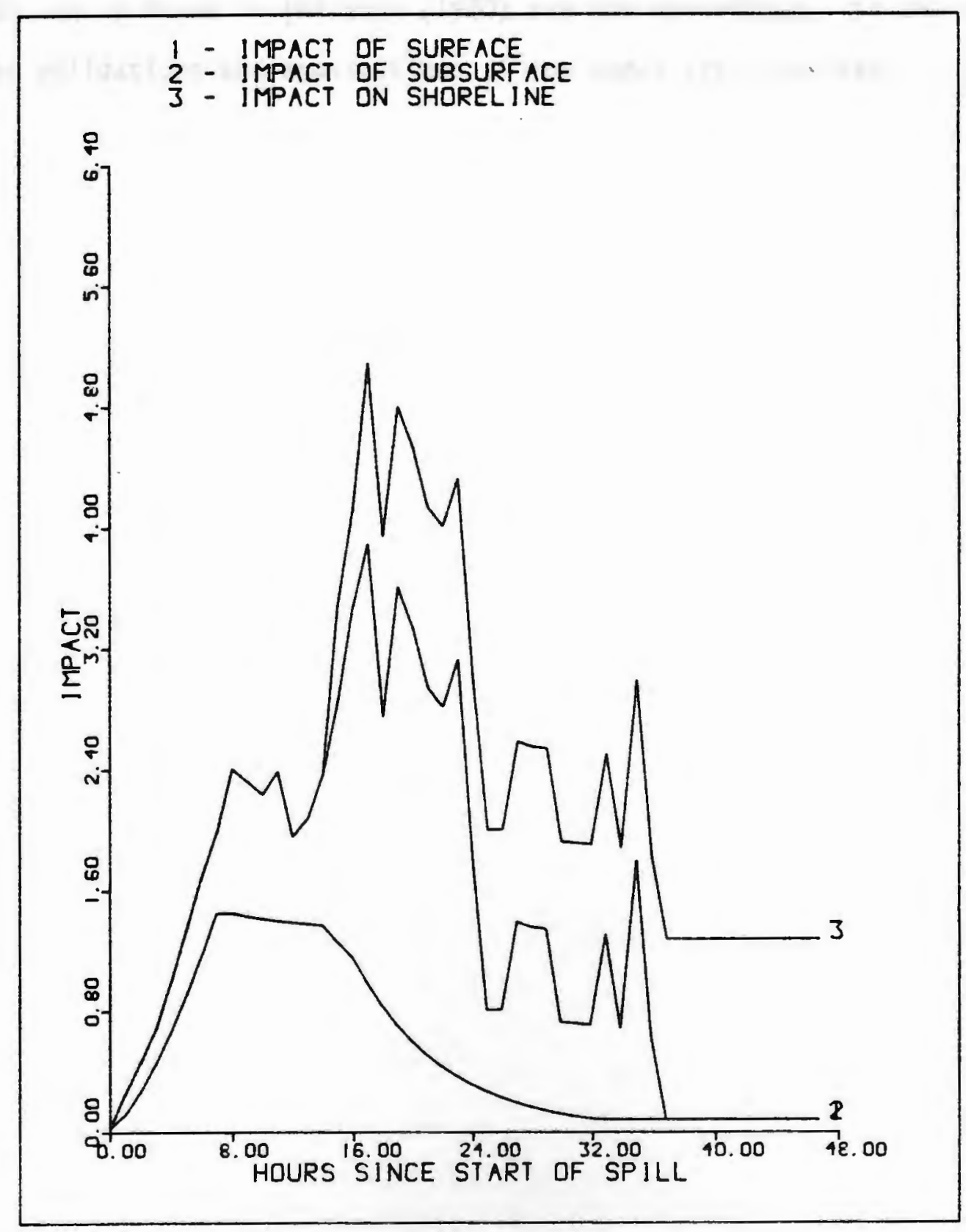

Figure 3-12 Plot of Impact 
various input parameters in order to study their effect. One example of this is shown in Figure 3-13, indicating the difference in impact between a minimum shoreline oil density of 1.0 and 2.0 tons per kilometer.

More details of the processes, responses and operation of the program can be found in [Wilson] (1980) and the Appendices. In the next chapter validations and applications of the model are presented. 
IMPACT OF SPILL

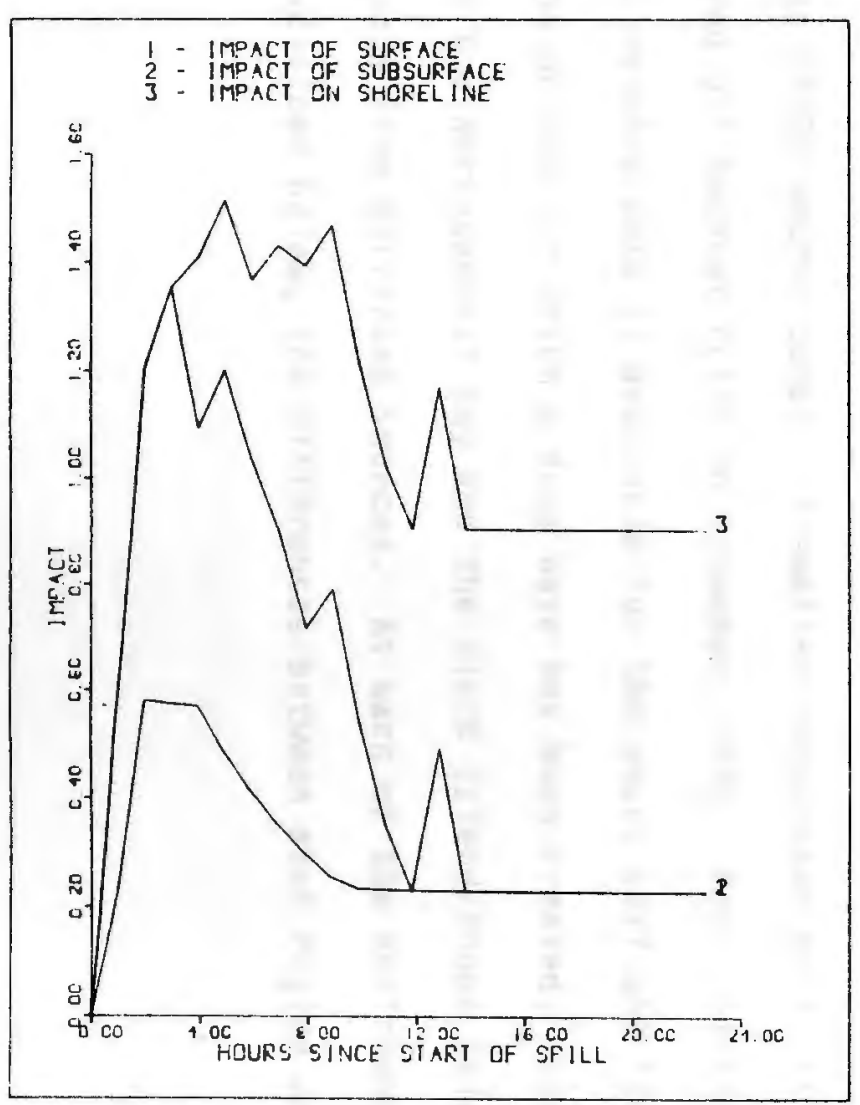

Minimum shoreline density 1 ton $/ \mathrm{km}$.
IMPACT OF SPILL

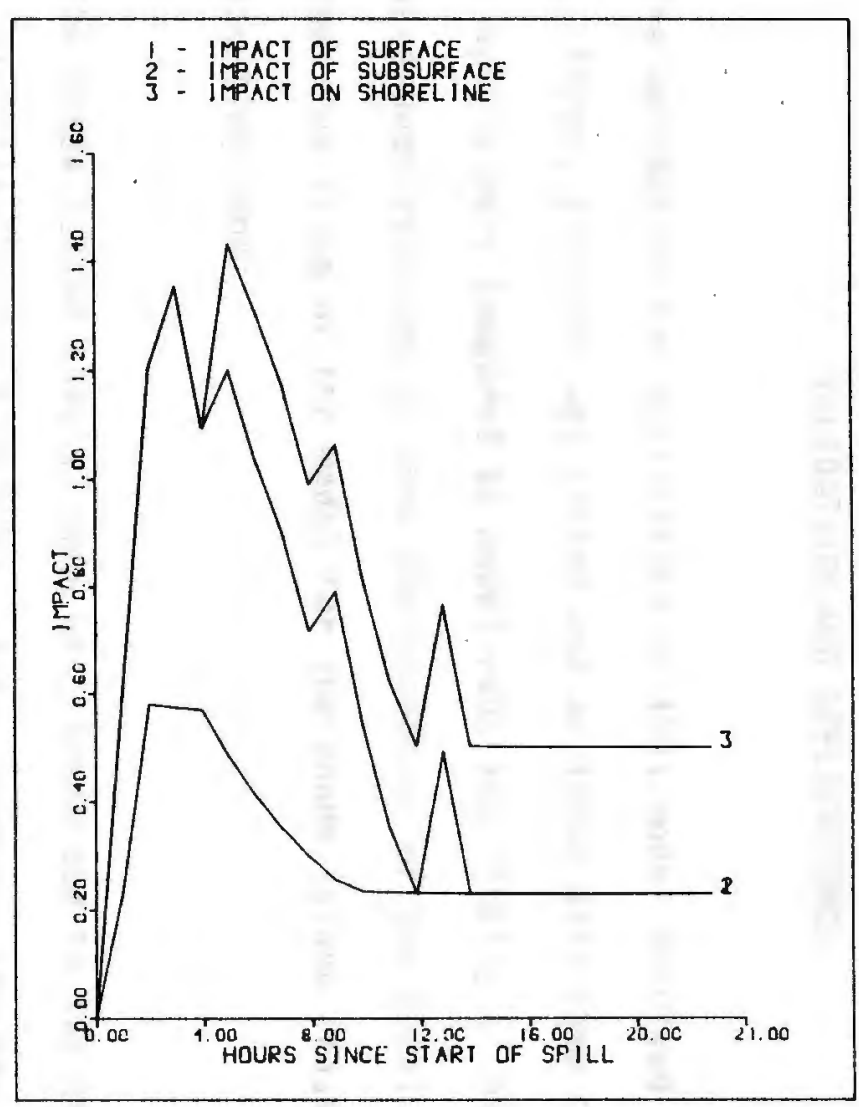

Minimum shoreline density 2 tons $/ \mathrm{km}$.

Figure 3-13 Examples of Impact Plots Using Different Criteria 


\section{CHAPTER IV}

\section{VALIDATION AND APPLICATIONS}

The validation and application of this model involved several steps. First, a region was picked and an input data base created. Next, actual spills were compared to model runs and finally a set of sample runs have been executed to show the potential of the model. This chapter describes the setup of the model for the Rhode Island coastal area and the resulting runs.

The Rhode Island coastal zone was chosen due to its proximity, and the availability of required data. Also, Narragansett Bay and the Block Is land/Rhode Is land Sounds have tankers passing through to Providence, New York and Boston (Be 11 1981) and thus provides potential for future spills. The largest spill documented was the vessel Pennant, which went aground in northern Narragansett Bay in April, 1973 spilling 252,000 gallons (1000 metric tons). A smaller documented spill of 1400 gallons occurred off Quonset Point in November, 1976. For training use, extensive wind data is available for the years 1977 and 1978 hence this was the period for which a data base has been created. The environmental inputs for Narragansett Bay and the Block Is land/Rhode Is land Sounds originate from different sources. As each of the environmental inputs are explained below, the differences between each region will be pointed out. 
Simulation Setup

Wind

Two sets of wind data were collected. The major source of Narrangansett Bay winds are observations from Green Airport in Warwick, R.I. Wind speed and direction is recorded every three hours although there are gaps in the data from time to time. For the Block Island/Rhode Is land Sound region, wind recorded in Charlestown, Rhode Is land during 1977 and 1978 is used. The data were taken hourly at a height of 33 meters (Snooks and Jacobson 1979). Gordon, (personal communication) found that the energy spectrum of the Charlestown data is very similar to the Green Airport data for times longer than one day.

Weather Service data has been used to simulate wind predictions. The U.S. Department of Commerce publishes a monthly summary of local weather which includes the resultant wind direction and speed each day. For use in this work, these data were rounded off to the nearest eight points of the compass and nearest increment of 5 knots so as to simulate typical information which would be passed to an on-scene commander. For example, a calculated resultant of 9 knots with a direction of 135 degrees will yield a prediction of Northwest winds at 5 to 10 knots. Additional examples of wind predictions will be seen during an application run later in this chapter. 
Currents

Current data for Narragansett Bay was based on Gordon (1982) who suggested that tidal currents are important for mixing and wind currents are significant for sub-tidal flows. At times, density and continental shelf events such as storms can greatly influence currents. Development of a sophisticated wind current model is not within the scope of this research so values from a tidal current model developed by spaulding and Swanson (1976) are used. This model calculates currents in a 68 by 112 rectangular grid with spacing of one-fifth of a nautical mile (see Figure 4-1). Currents from this tidal model are entered into the main program approximately every one-half hour. To save time and space, only about one-half of the grids are used for a simulation.

Several studies serve as a background for the selection of the currents in Block Is land and Rhode Island Sounds. Collins (1977) carried out a study using 600 surface and bottom drifters. Drifters do not give accurate speeds but trends can be established and this study indicates that northerly and north-westerly winds cause the surface currents to move offshore in the winter. During the summer, south-westerly winds cause the opposite effect. The bottom currents generally move opposite the surface but are more complex due to bottom topography. A study by Shonting (1969) indicates that the surface currents are predominantly non-tidal but the bottom currents are rotary similar to tidal currents. The latest research indicates that most of the energy is in tidal 
Figure 4-1 Narragansett Bay Grid
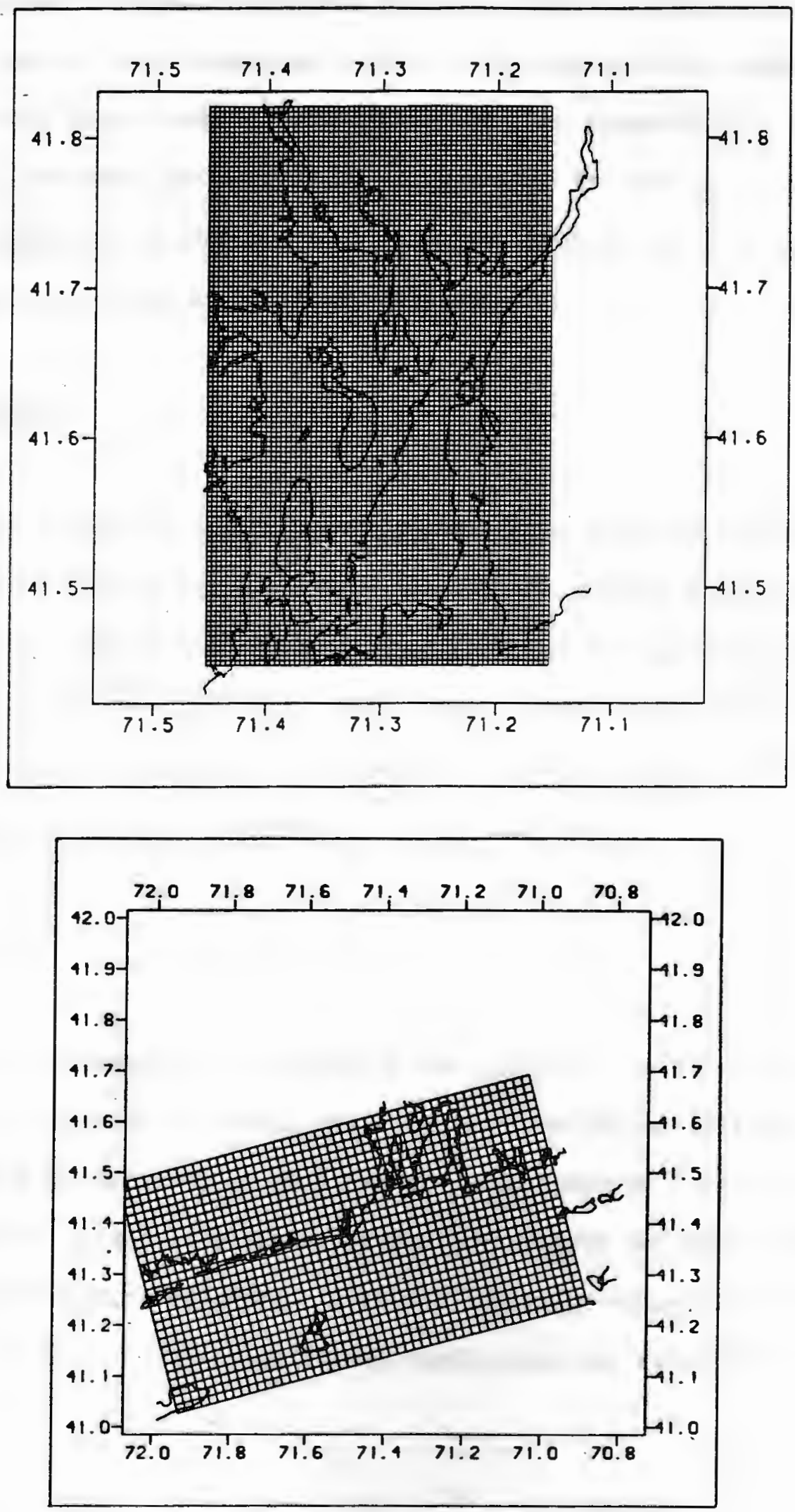

Figure 4-2 Block Isiand/Rhude Island Sound Grid 
currents and that this energy increases with distance offshore and somewhat with depth (Snooks and Jacobson, 1981). Since a tidal current model is available (Beachamp 1979), it is used for this study. The model covers the shelf from the western end of Long Island Sound to Buzzards Bay but for this application, just a portion is used (Figure $4-2$ ). The grid separation is one nautical mile and makes an angle of about 15 degrees with lines of constant latitude.

\section{Temperature}

For sea water temperature, data has been obtained from various sources including Snooks and Jacobson (1979), Gordon (1982) as well as various personnel from the Graduate School of Oceanography at the University of Rhode Island. The values in Table 4-1 are average because the actual temperatures vary greatly, especially within the Bay, depending upon depth, weather and tidal motions.

Sea State

Very little sea state data is available for this region but it is needed to calculate cleanup efficiencies. Bellantoni (1979) discusses sea state probability which gives the percentage of time that the waveheight exceeds a given value during a season but this is based on ship observations offshore. A set of sea state values for Narragansett Bay and Block Is.land/Rhode Island Sound Areas was calculated from the 
TABLE 4-1. Average Monthly Water Temperature $\left({ }^{\circ} \mathrm{C}\right)$

\section{NARRAGANSETT}

MONTH

Jan.

Feb.

March

April

May

June

JuTy

Aug .

Sept.

Oct.

Nov.

Dec.
BLOCK ISLAND SOUND

6.9

5.3

5.0

6.4

9.2

14.4

18.6

20.4

18.0

15.5

12.4

9.4
BAY

1.5

1

4

7.75

11.5

17

20

22

12

10

8

2 
Shore Protection Manual (1975) using the forecasting curves. The definition of sea state is based on the minimum wave height values in Table 4-2. The wind data every three hours from Green Airport was used for the entire region. The bay is fetch limited to one nautical mile in the east-west direction and twenty nautical miles in the north-south direction. The values in Table 4-3 are assigned to the entire bay although in reality coves and inlets would have smaller waves. When reviewing the sea states calculated for 1977 and 1978, it is rare that a sea state of 2 is exceeded and this is consistent with the limited reports available for the Narragansett Bay. For the Sound region, the waves are fetch limited if the wind is from the north east or west but are not if the wind is from the south. The winds from the south are assumed to be duration limited to nine hours for this application.

Bathymetry

Depths for these runs were gathered from charts by choosing points which coincided with the current grids. The Narragansett Bay depth grid is one-fifth of a nautical mile and the spacing in the Sounds is one-half of a nautical mile.

Coastline

The shoreline has been digitized and stored using longitude and latitude and each point is assigned a coastline type. The shoreline of 
TABLE 4-2. Sea State Wave Heights

$\begin{array}{cc}\text { SEA STATE } & \text { MINIMUM WAVE HEIGHT } \\ 0 & 0.0 \\ 1 & 0.75 \\ 2 & 2.2 \\ 3 & 4.0 \\ 4 & 6.4 \\ 5 & 10.0 \\ 6 & 14.0\end{array}$


TABLE 4-3. Assigned Sea States

\section{NARRAGANSETT BAY}

WIND (Knots) East-West (1 Mile Fetch) North-South (20 mile
Fetch)

$\begin{array}{lll}0 & 0 & 0 \\ 10 & 0 & 1 \\ 20 & 1 & 2 \\ 30 & 2 & 3\end{array}$

\section{BLOCK ISLAND SOUND}

\begin{tabular}{rcccccc} 
WIND & East-west & North & WIND & \multicolumn{3}{c}{ South (Limited Duration) } \\
& $(21$ mile Fetch $)$ & $(7$ mile Fetch) & 3 (hours) & 6 & 9 \\
0 & 0 & 0 & 0 & 0 & 0 & 0 \\
10 & 1 & 0 & 5 & 0 & 1 & 1 \\
15 & 1 & 1 & 10 & 1 & 2 & 2 \\
20 & 2 & 1 & 15 & 2 & 2 & 3 \\
25 & 2 & 2 & 20 & 3 & 3 & 4 \\
30 & 3 & 3 & 25 & 3 & 4 & 5 \\
730 & 4 & 3 & 30 & 4 & 4 & 5 \\
& & & 35 & 4 & 5 & 6 \\
& & & 735 & 5 & 6 & 6
\end{tabular}


the bay seen in Figure 4-1 contains 11,700 points with an average separation of about 45 meters. There are 3,200 points in the Sound's shoreline (Figure 4-2) with an average spacing of 223 meters. The information for the type of shoreline is based on 01 sen (1980) and the Coastal Resources Center (1980) with additional information taken from maritime charts.

Equipment

The characteristics and locations of the equipment available are predominantly taken from the Coast Guard's SKIM output for this region. Information for a local cooperative, Clean Atlantic Associates, was obtained from Allen (1982) while Premack (1975) supplied information concerning municipal equipment. Some equipment from outside the region is listed by Bellantani (1979). Generic equipment types have been added to insure that the user will not deplete the stored equipment. For example, there are five units of each class of skimmer stored in Providence, in addition to any others listed in SKIM.

\section{Process Validation}

The process validation uses data from two different spills in Narragansett Bay. Sample runs have been performed and the model results compared to reports concerning the actual spill. Data from a small spill 
which occurred off Quonset Point in 1976 has been reported by Noll and Spaulding (1977). The On-Scene Coordinators report supplied information about the spill of the merchant vessel PENNANT in 1973.

Quonset Point Spill

The first spill used for validation occurred on the morning of November 9, 1976 near Quonset Point. It was estimated that 1400 gallons (5.7 metric tons) was spilled and washed ashore at Sand Cove on Prudence Island. The plots showing the run are presented in Figure 4-3. The final mass distribution is shown in Figure 4-4 and it indicates that all three spillets simulated are completely ashore within about 20 hours. The trajectory of the surface oll was similar to that of a previous simulation by Noll and Spaulding. This was expected given that the same environmental parameters, wind drift angle of twenty degrees and a drift factor of $31 / 2$ percent were used, but it does show that the formulation of the model is consistent with that of Noll and Spaulding. Also simulated in this run was the behavior of the subsurface oil. The minimum concentration within the square sections in figure $4-3$ is .001 $\mathrm{gm} / \mathrm{cm}^{3}$ (10 parts per billion). The subsurface is spread out over a large area for more than two days after the initial spill. In narrow estuaries such as Narragansett Bay, cyclic tidal currents alone cannot disperse subsurface oil, it is usually lost through interactions with the shore or the bottom. Figure 4-5 shows the impact of a minimum subsurface concentration of $100 \mathrm{ppb}$. After about 21 hours, the contribution to the 
3.9 HOURS AFTER START OF THE SPILL MAP OF SPILLETS AND SUBSURFACE

$\infty$
$\infty$

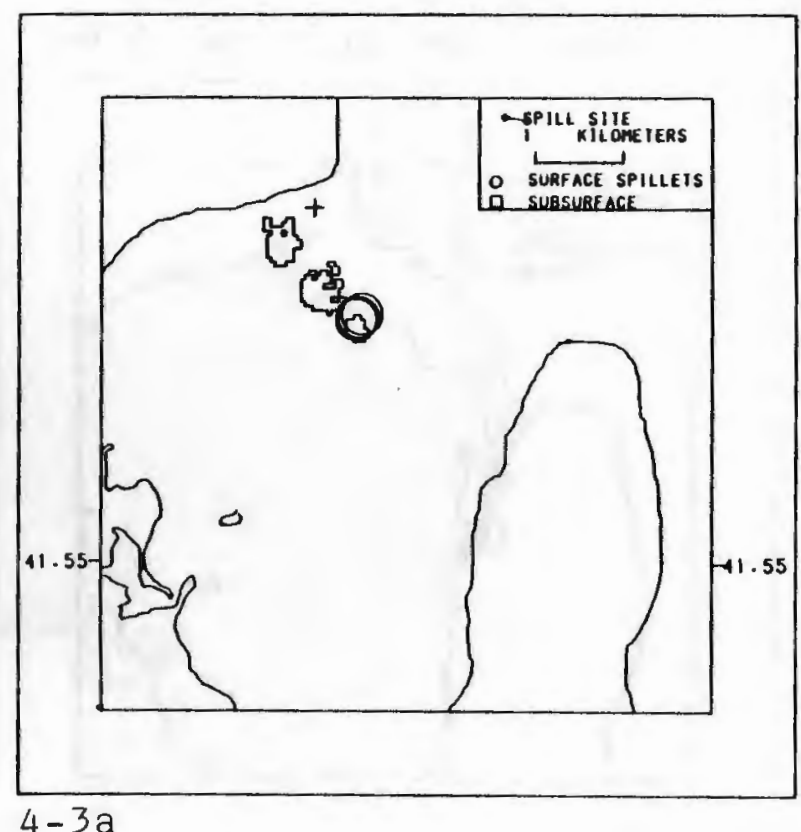

Figure 4-3 0il Locations
7.9 HOURS AFTER START OF THE SPILL MAP OF SPILLETS AND SUBSURFACE

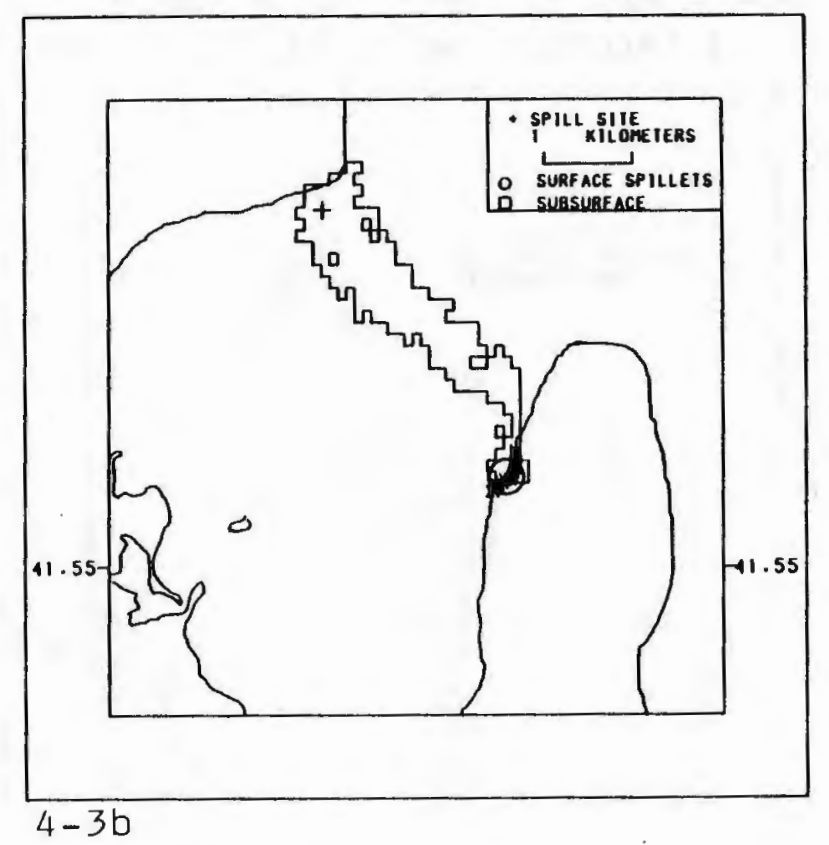

or Quonset Point Simulation 
11.8 HOURS AFTER START OF THE SPILL MAP OF SPILLETS AND SUBSURFACE

$\underset{0}{\infty}$

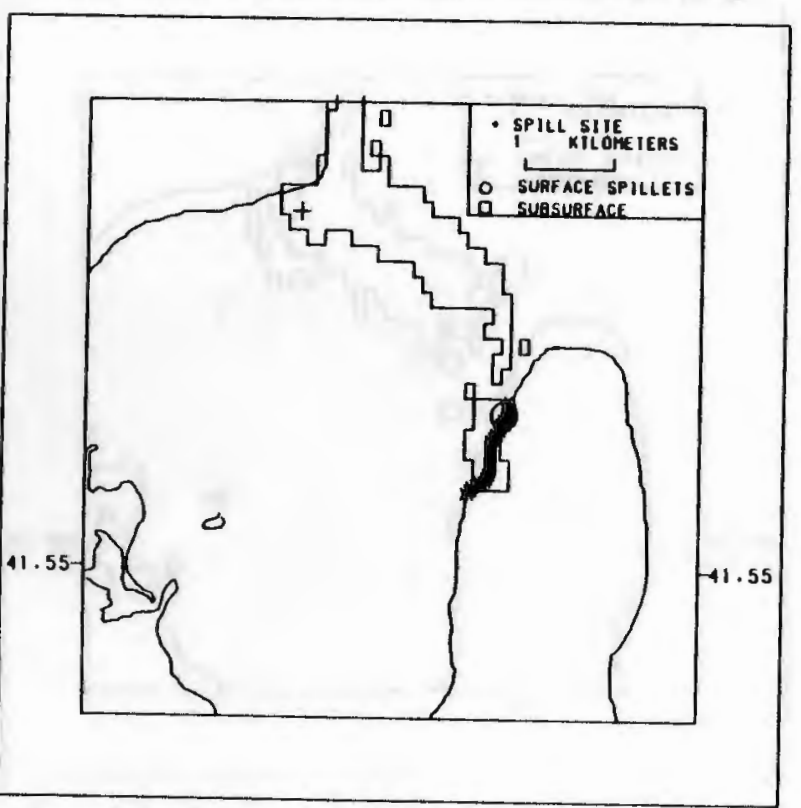

Figure $4-3 c$
15.8 HOURS AFTER START OF THE SPILL MAP OF SPILLETS AND SUBSURFACE

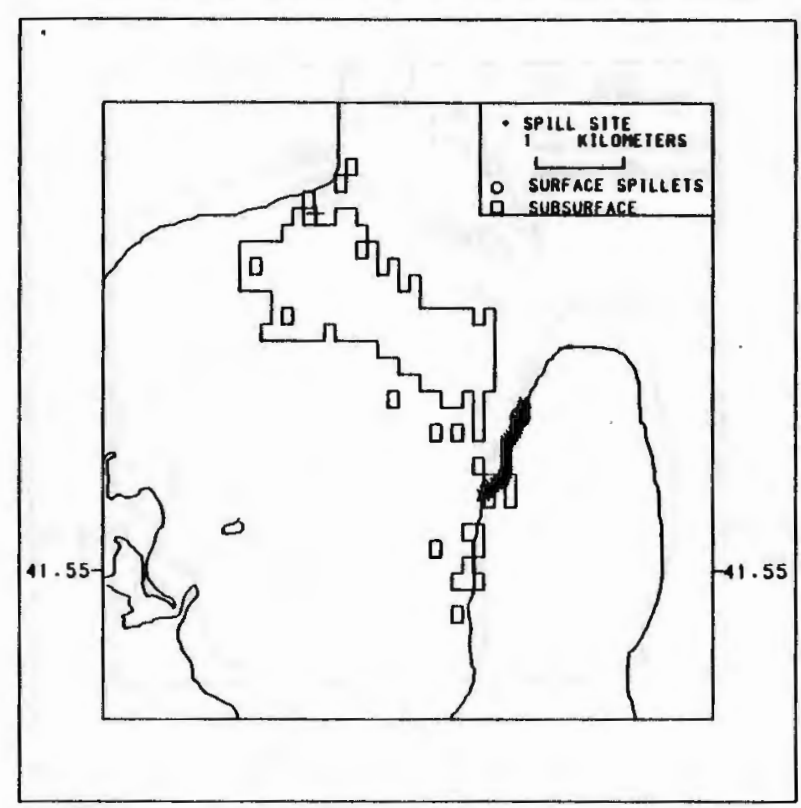

Figure 4-3d 
19.7 HOURS AFTER START OF THE SPILL MAP OF SPILLETS AND SUBSURFACE

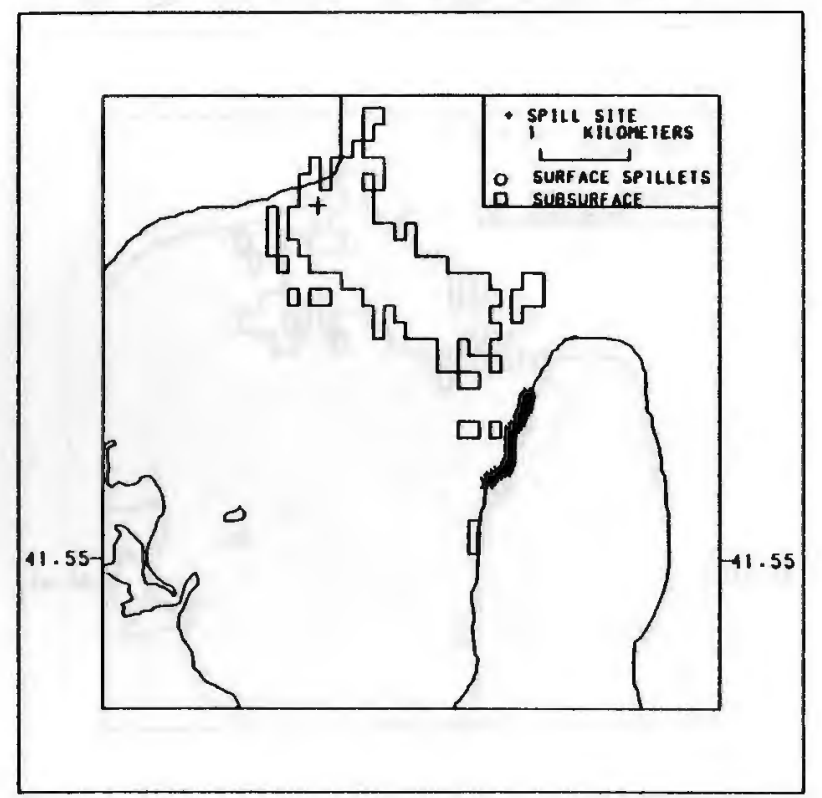

Figure $4-3 e$
23.7 HOURS AFTER START OF THE SPILL MAP OF SPILLETS AND SUBSURFACE

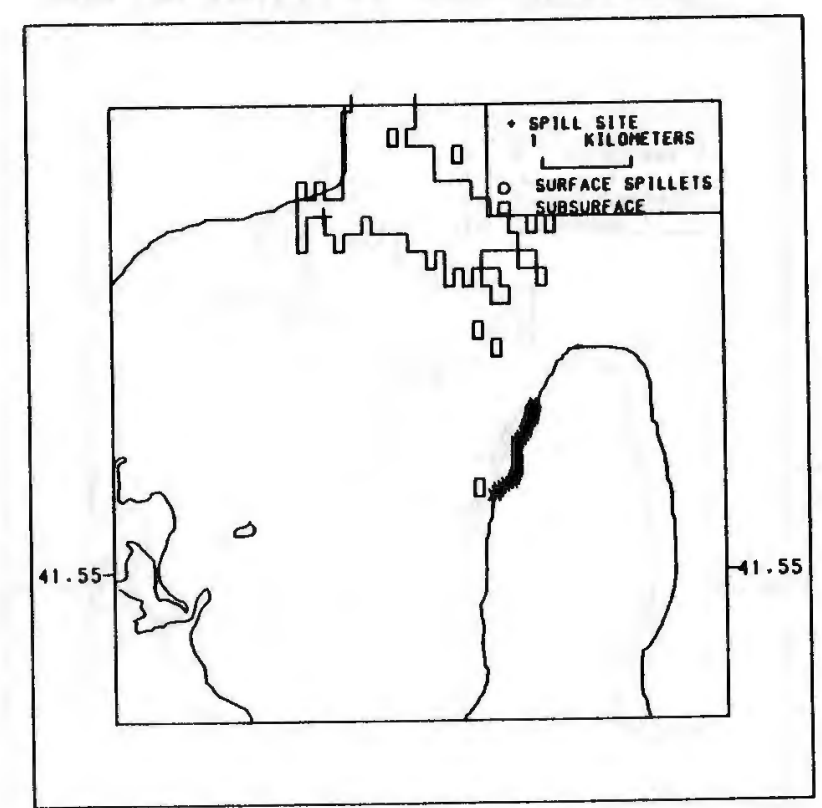

Figure $4-3 f$ 
27.6 HOURS AFTER START OF THE SPILL MAP OF SPILLETS AND SUBSURFACE

$\stackrel{6}{\longmapsto}$

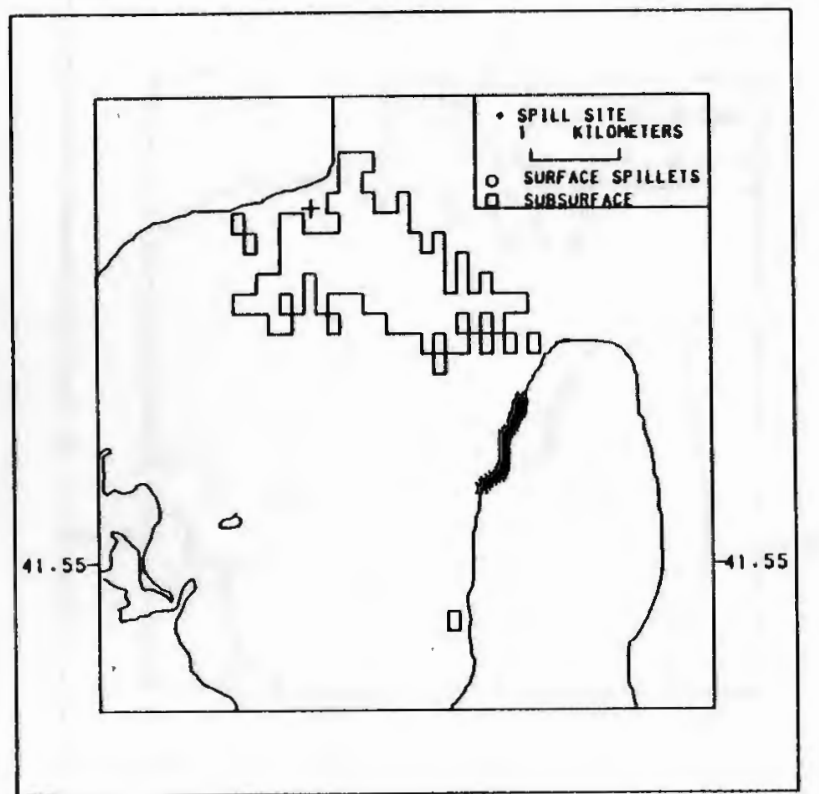

Figure $4-3 g$
31.6 HOURS AFTER START OF THE SPILL MAP OF SPILLETS AND SUBSURFACE

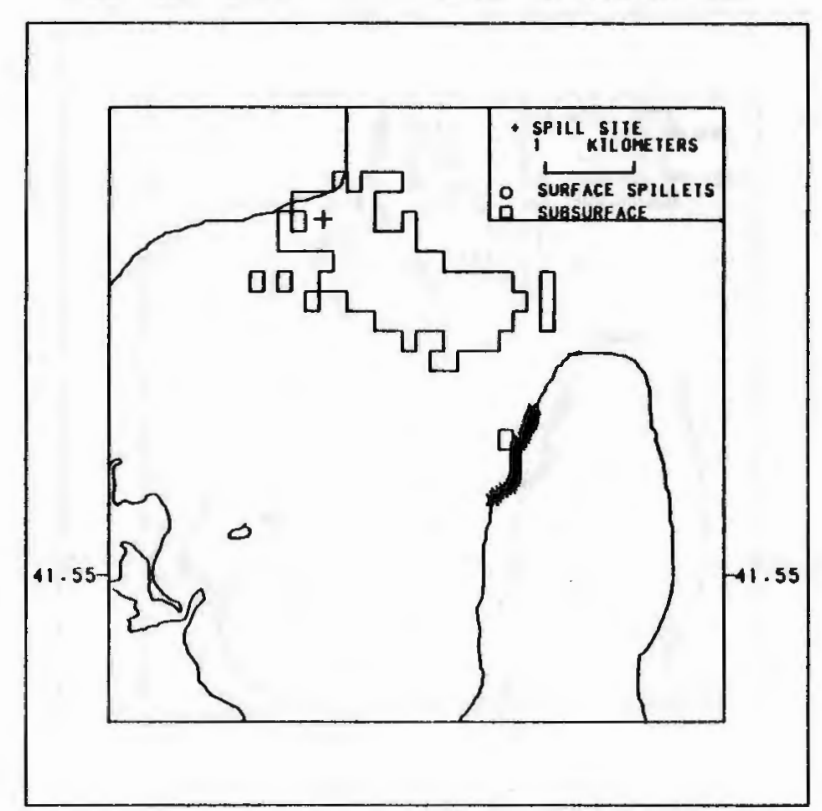

Figure 4-3h 
35.5 HOURS AFTER START OF THE SPILL MAP OF SPILLETS AND SUBSURFACE

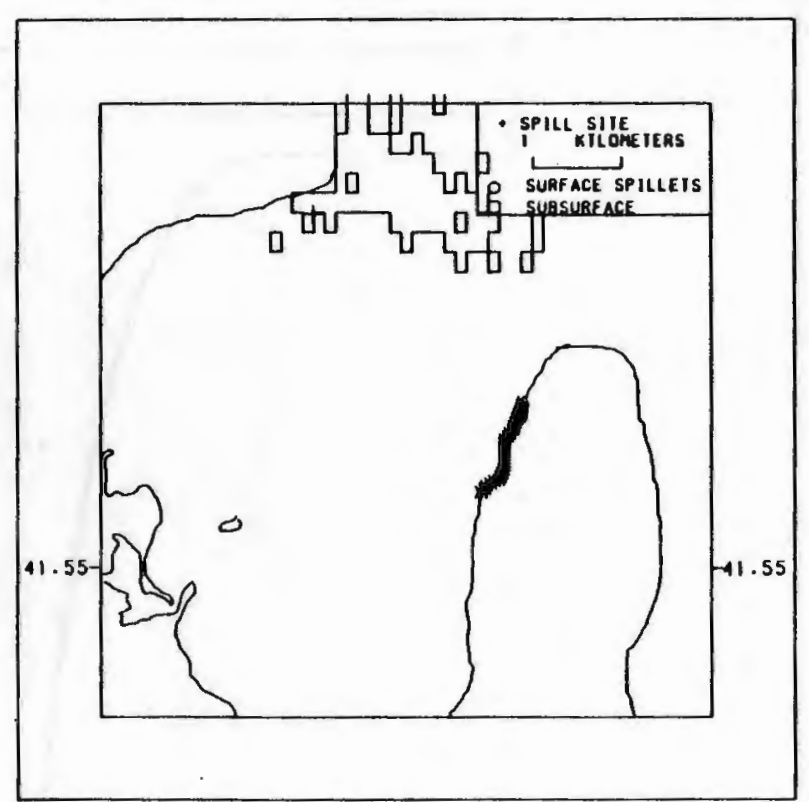

Figure 4-3i
39.5 HOURS AFTER START OF THE SPILL MAP OF SPILLETS AND SUBSURFACE

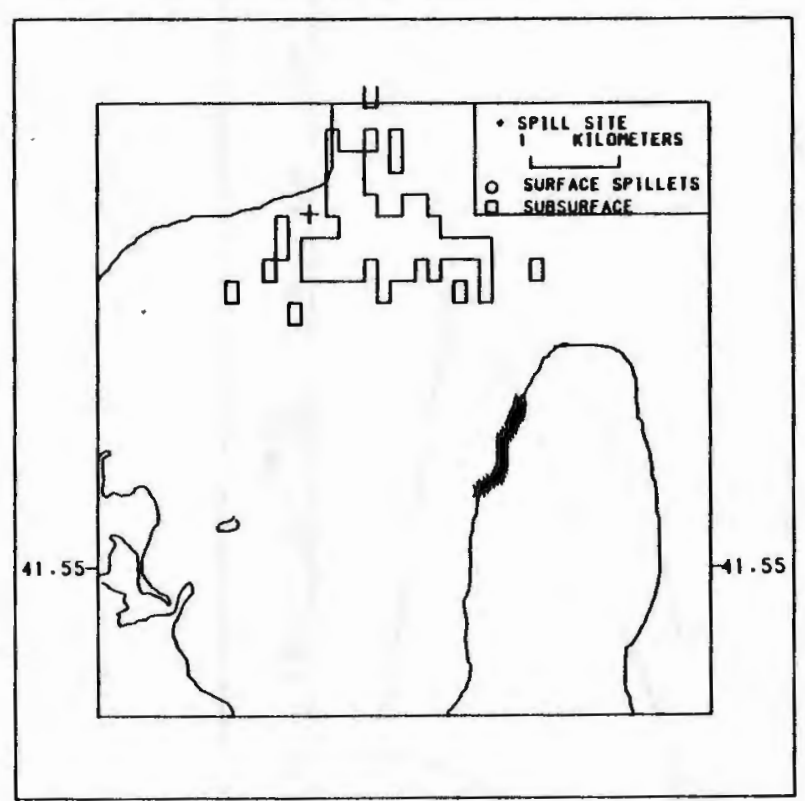

Figure $4-3 j$ 


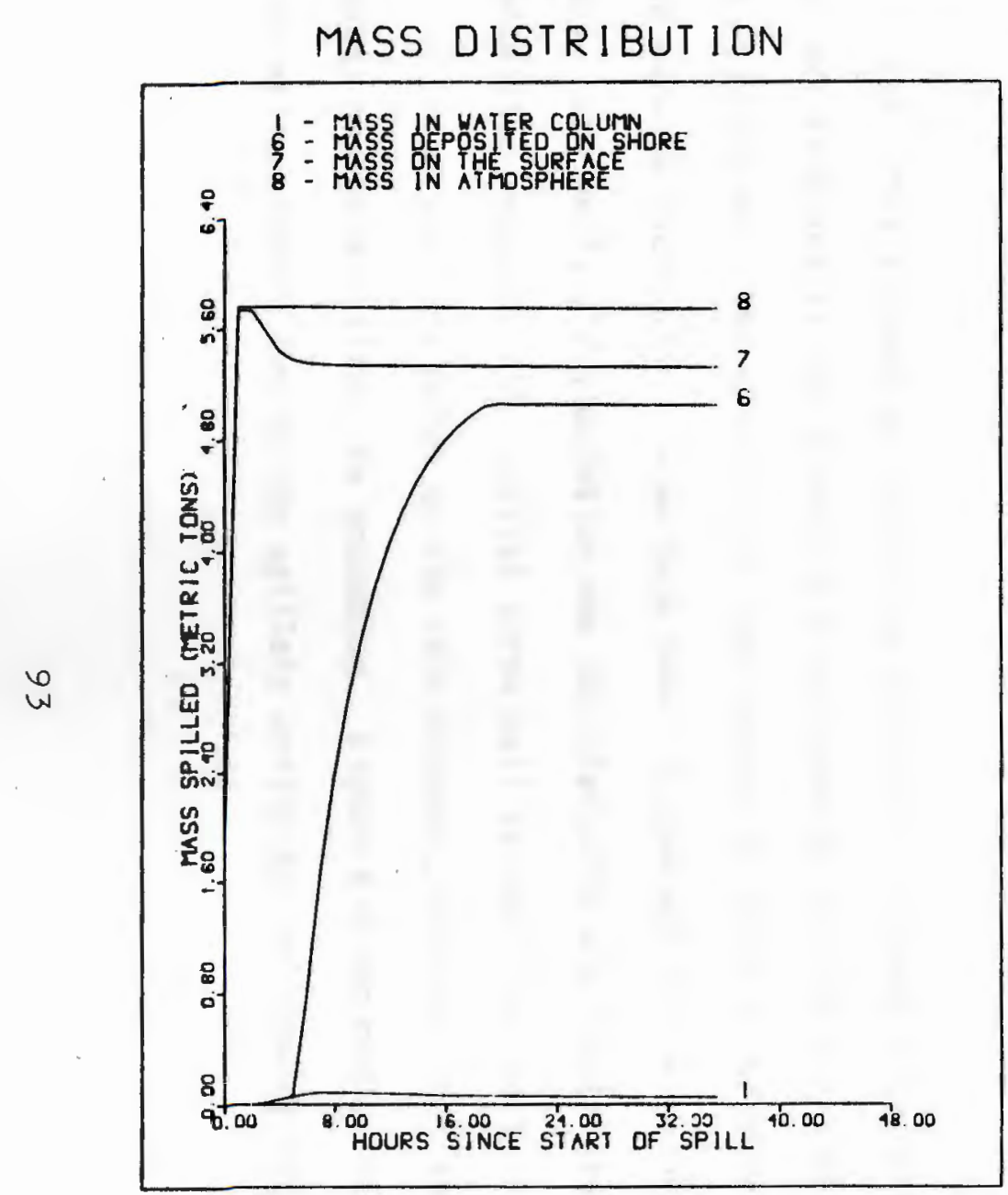

Figure 4-4 Quonset Point Simulation Mass Distribution
IMPACT OF SPILL.

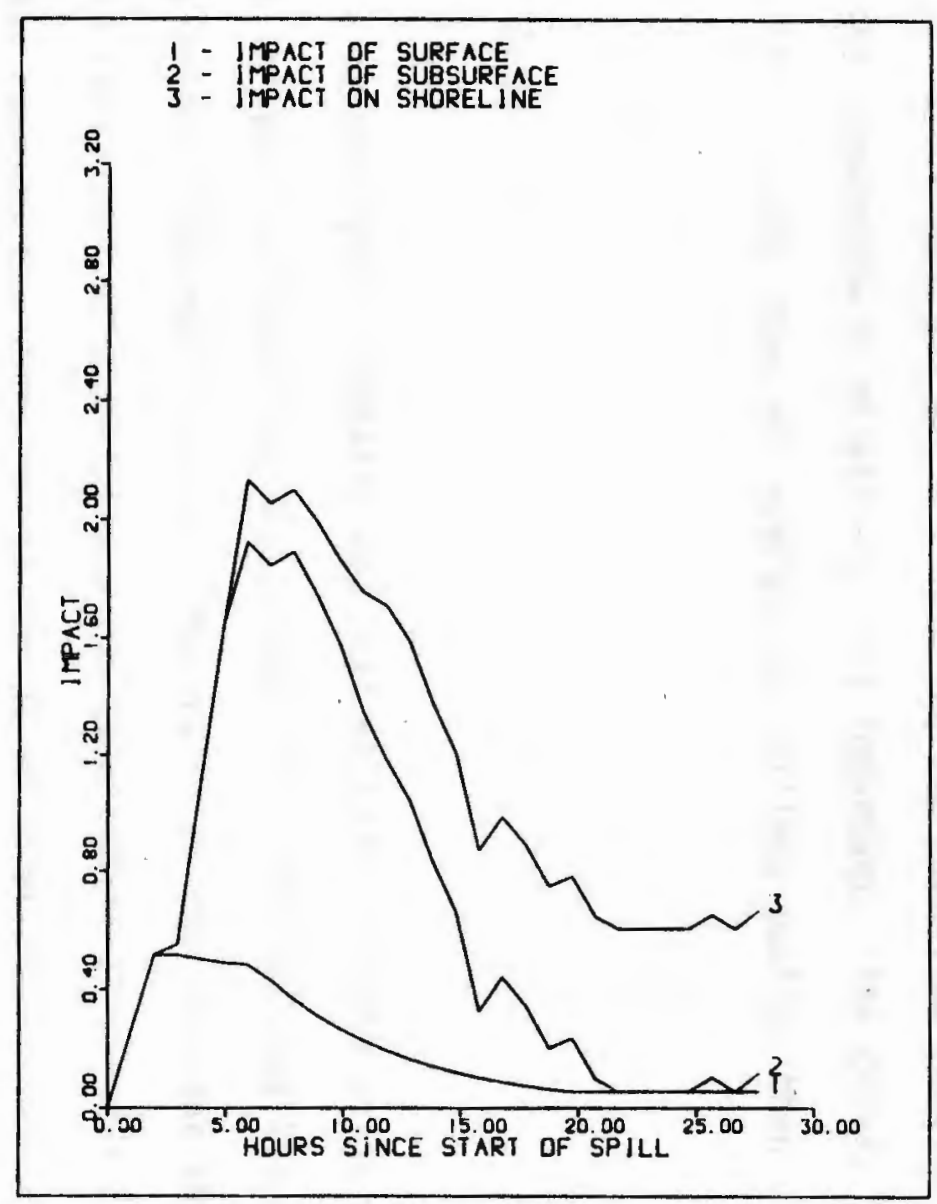

Figure 4-5 Quonset Point Simulation Impact 
impact of the surface oil and oil reaching the shoreline remains the same. The subsurface is relatively less important. The curves level off because the program, does not operate on spillets smaller than .1 metric tons.

Pennant Spill

The second spill simulated was that of LI/TK Pennant which went aground in upper Narragansett Bay on April 9, 1973 spilling 252,000 gallons (about 1000 metric tons). The report of the on-scene commander (Pennant 1973) indicates that heavy oil came ashore at Warwick (point B) and later covered the shoreline at the other three points ( $A, C$ and $D$ ) noted in Figure 4-6a. Ultimately, a total of 13.6 kilometers of coastline was oiled, the heaviest area hit being the $01 d$ Mill Creek area in Warwick which is just above point $B$.

The first attempt at simulating this spill assumed that most of the oil was released at the grounding site shown as a cross near the bottom of Figure 4-6a. The spill first came ashore at point $A$ but never touched the Warwick shore (B). Given that this run did not simulate the observed spill very well, the simulation was repeated with the twenty degree wind deflection removed. The initial three spillet positions were spread over $11 / 2$ hours and four miles up the ship channel, assuming that the tanker leaked during and after the grounding. Figure 4-6 documents this simulation showing two of the spillets arrive on the Warwick shore. 
5.9 HOURS AFTER START OF THE SPILL MAP OF SPILLETS AND SUBSURFACE

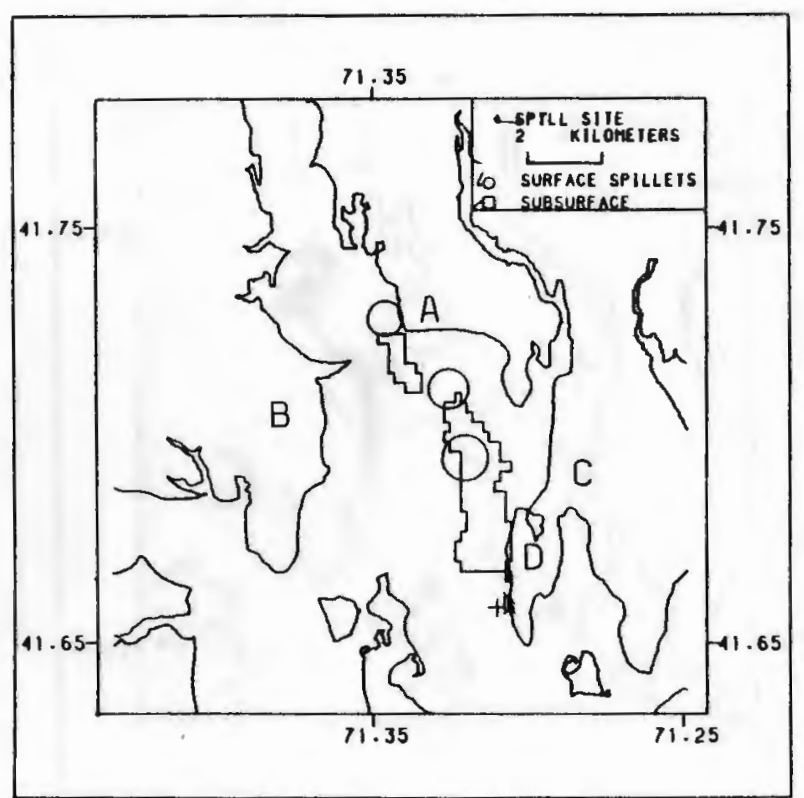

Figure 4-6a
11.8 HOURS AFTER START OF THE SPILL MAP OF SPILLETS AND SUBSURFACE

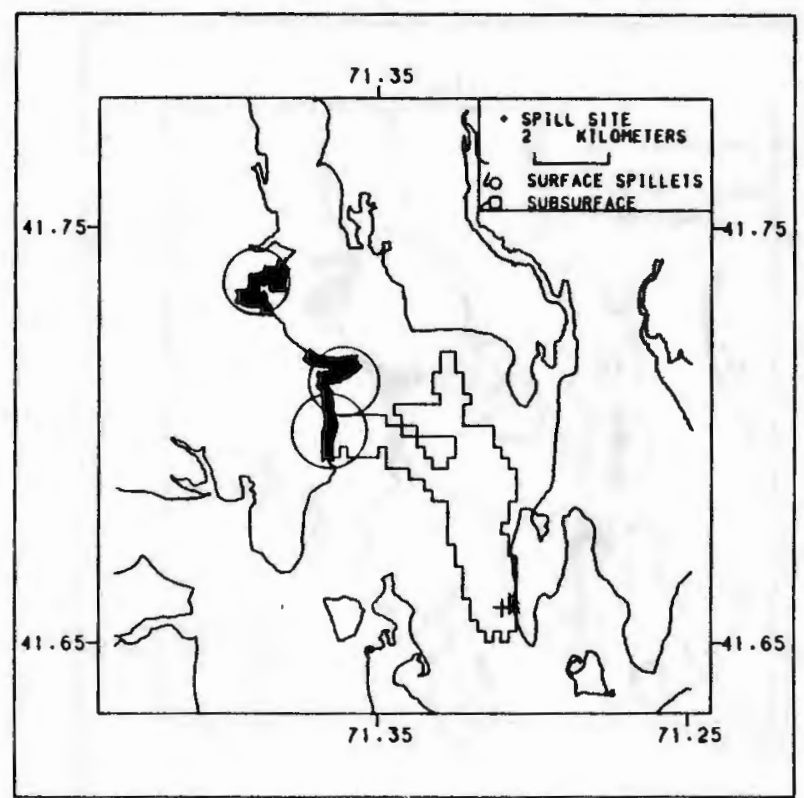

Figure 4-6b

Figure 4-6 0il Locations for Pennant Simulation 
17.8 HOURS AFTER START OF THE SPILL MAP OF SPILLETS AND SUBSURFACE

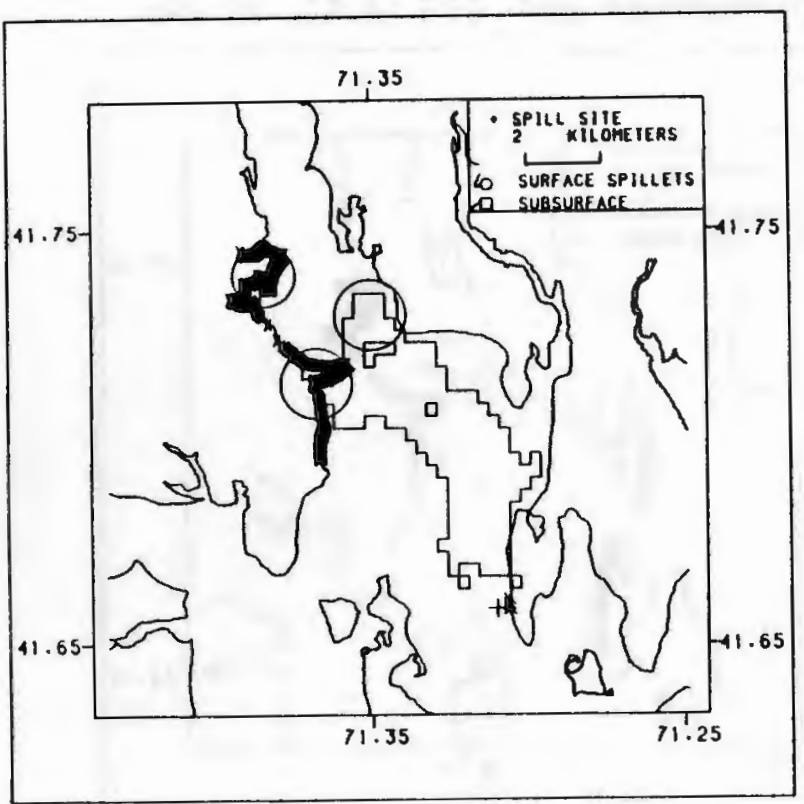

Figure $4-6 c$
23.7 HOURS AFTER START OF THE SPILL MAP OF SPILLETS AND SUBSURFACE

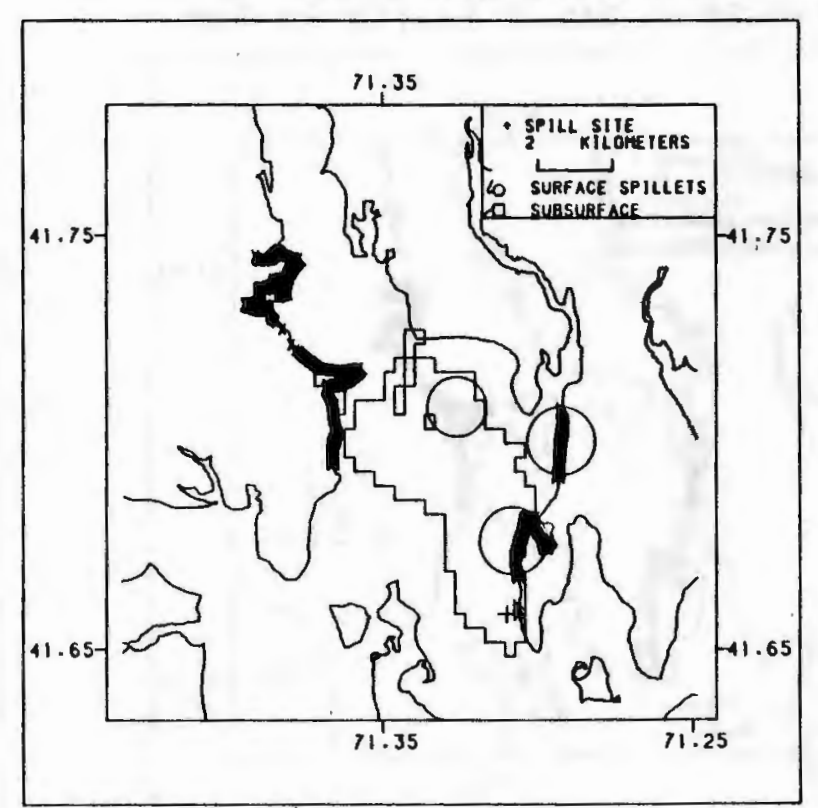

Figure 4-6d 
29.6 HOURS AFTER START OF THE SPILL MAP OF SPILLETS AND SUBSURFACE

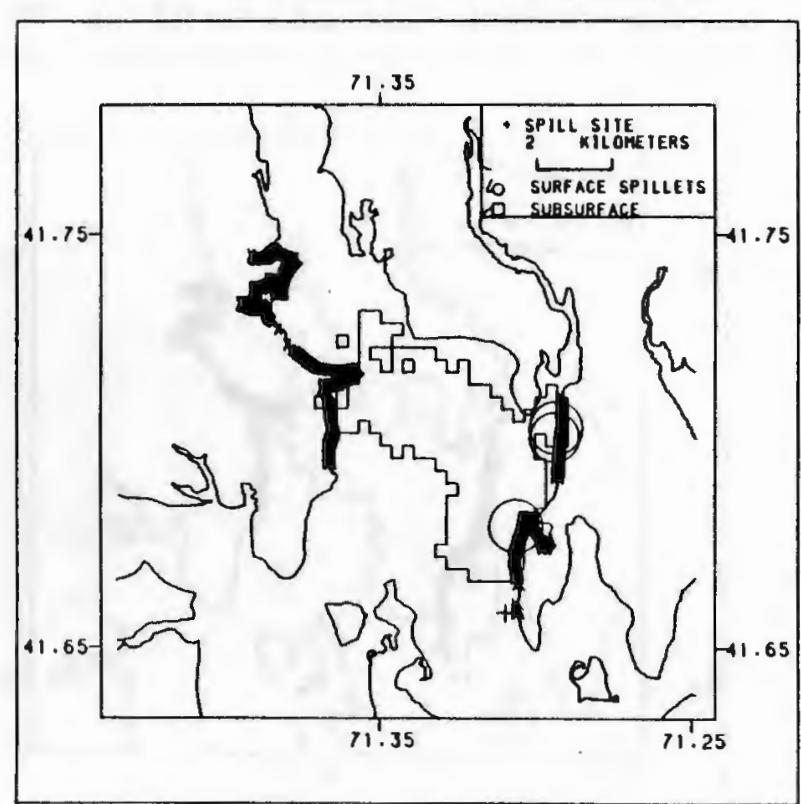

Figure $4-6 e$
35.5 HOURS AFTER START OF THE SPILL MAP OF SPILLETS AND SUBSURFACE

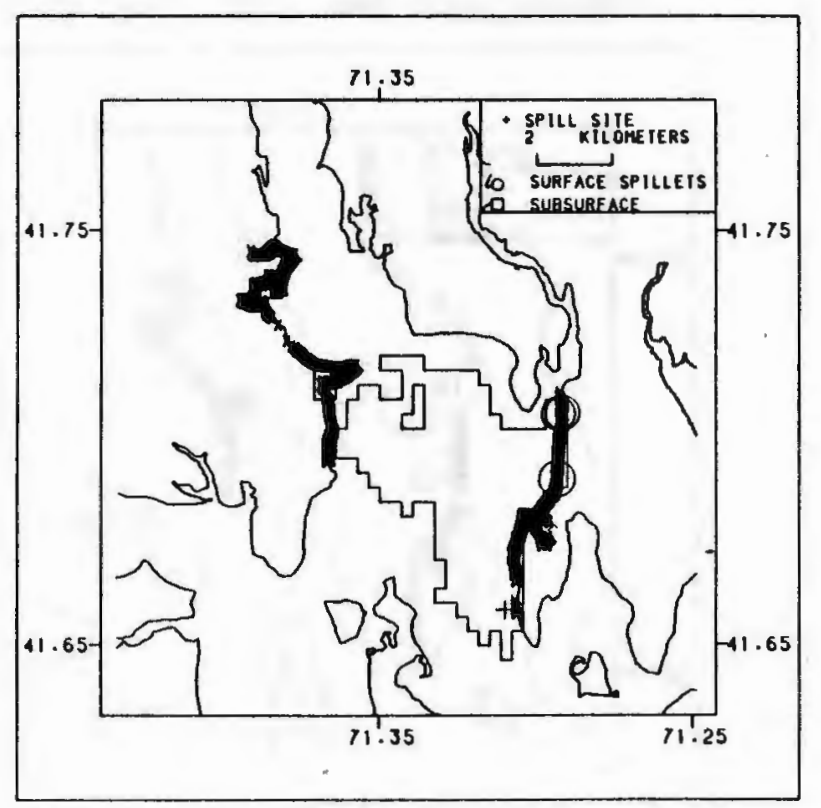

Figure 4-6f 
41.4 HOURS AFTER START OF THE SPILL MAP OF SPILLETS AND SUBSURFACE

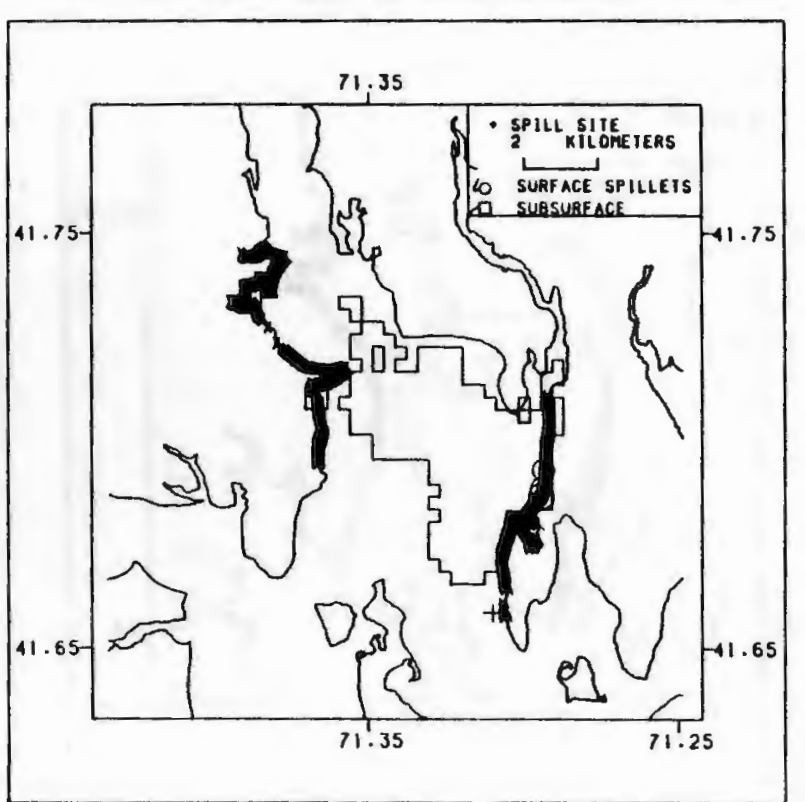

Figure 4-6g
47.4 HOURS AFTER START OF THE SPILL MAP OF SPILLETS AND SUBSURFACE

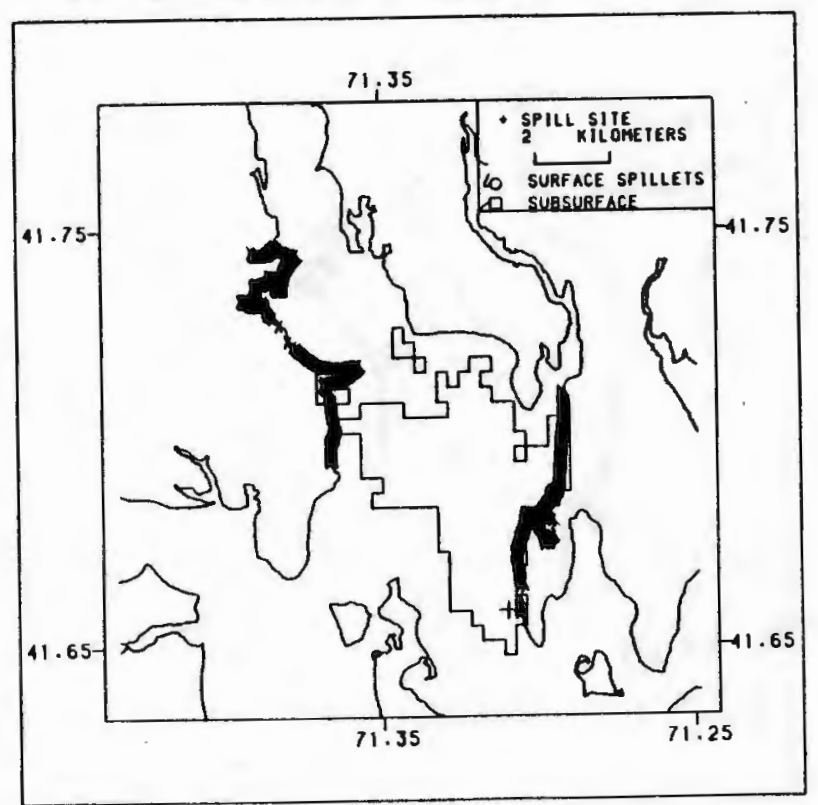

Figure 4-6h 
59.2 HOURS AFTER START OF THE SPILL MAP OF SPILLETS AND SUBSURFACE

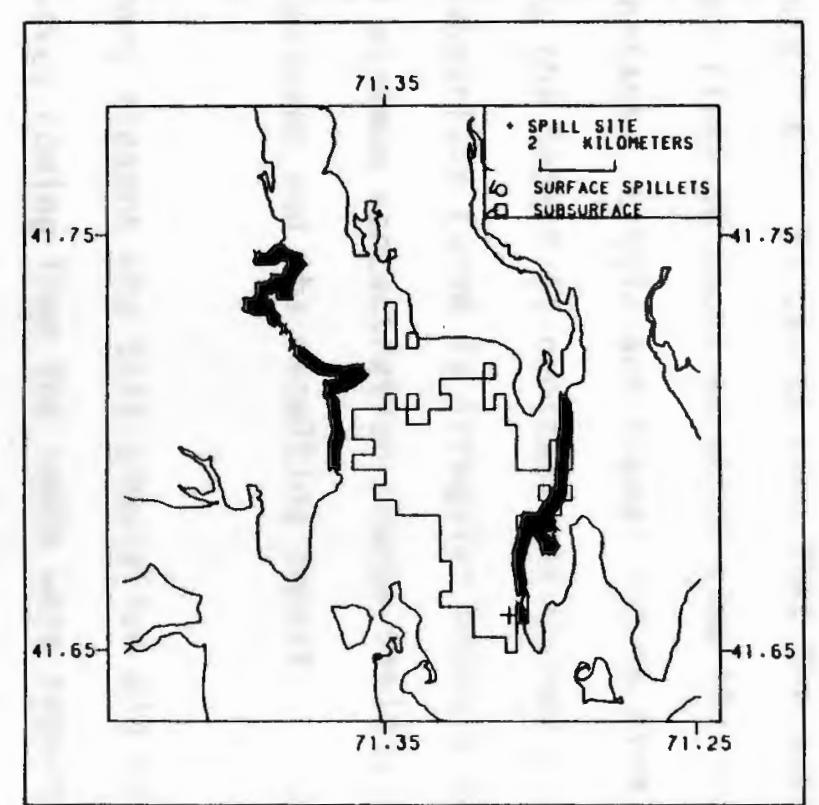

Figure 4-6i
88.8 HOURS AFTER START OF THE SPILL MAP OF SPILLETS AND SUBSURFACE

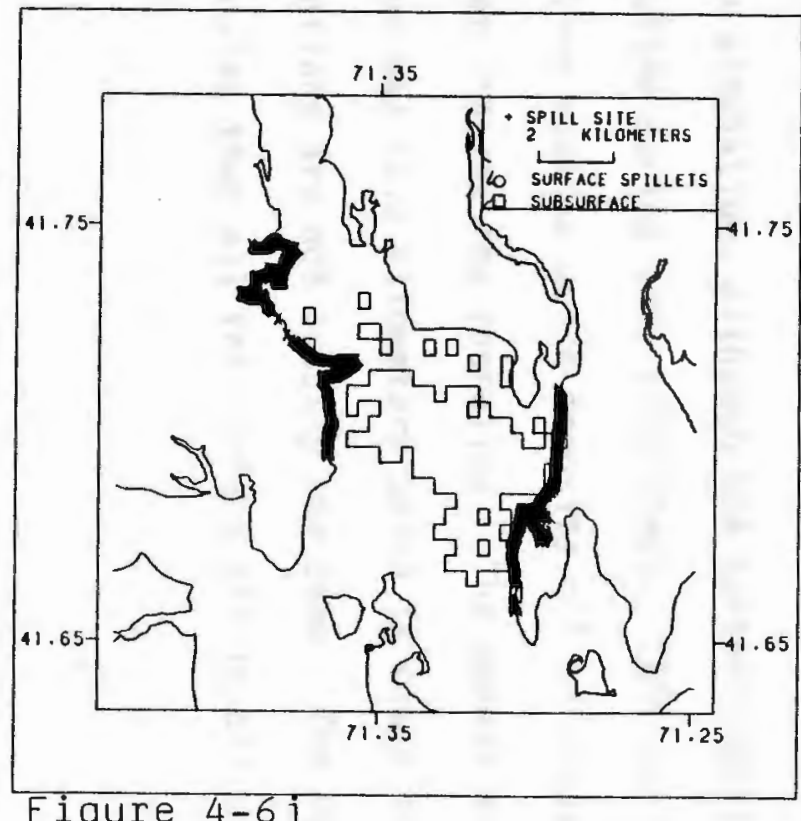


During the actual spill, some oil did come ashore very early south of North Point (point $D$ ) but the markings in Figure 4-6a indicate that only subsurface particles have come ashore here. No oil was stranded at point $A$ during the simulation, although the northern-most spillet overlaps the shoreline during some time steps. This was due to the shoreline interaction routine which deposits oil on shore only when the center of a spillet crosses the shoreline. The amount of shoreline oiled for this simulation was 12.3 kilometers which is close to the original value but the locations are not exactly the same. The mass distribution (Figure 4-7) indicates that all the surface oil is dispersed within 48 hours.

A minimum concentration of 50 parts per billion was chosen for the impact plot (Figure 4-8). It can be seen that the subsurface dominates the impact for the first 48 hours at which time the shoreline impact becomes more important. Little additional oil is stranded after the first 50 hours so the impact is constant and curves 2 and 3 are identical in shape. The subsurface curve is irregular because the number of grids which exceed the minimum concentration change rapidly resulting in changes in area exposed and the resulting impact.

There are many reasons why this simulation did not match the actual spill. First, waves coming from the south were reported to be as high as four feet during the first eight hours of the spill. This could have caused ofl to come ashore along the northern coast where this model does 
MASS DISTRIBUTION

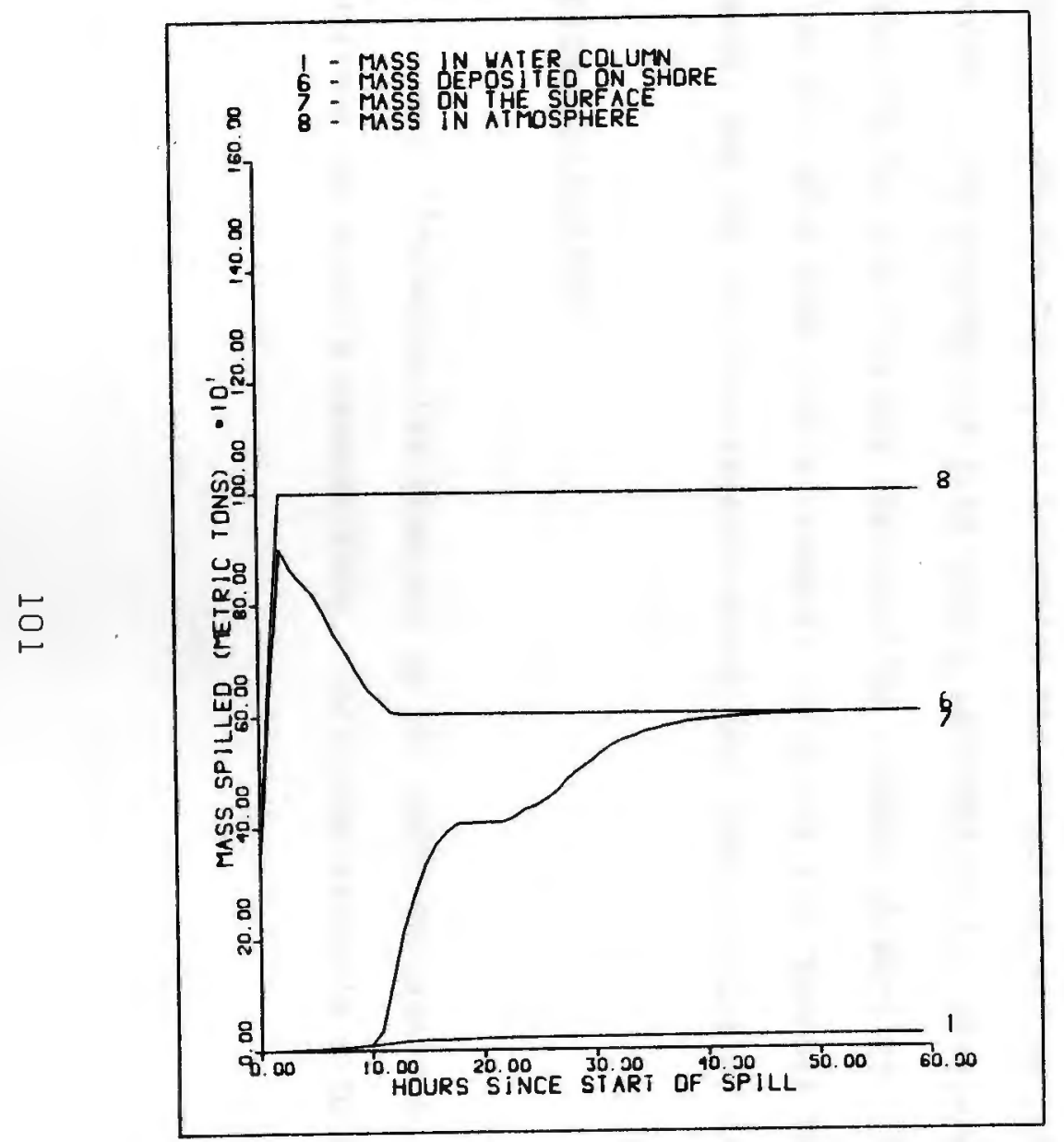

Figure 4-7 Pennant Simulation Mass Distribution
IMPACT OF SPILL

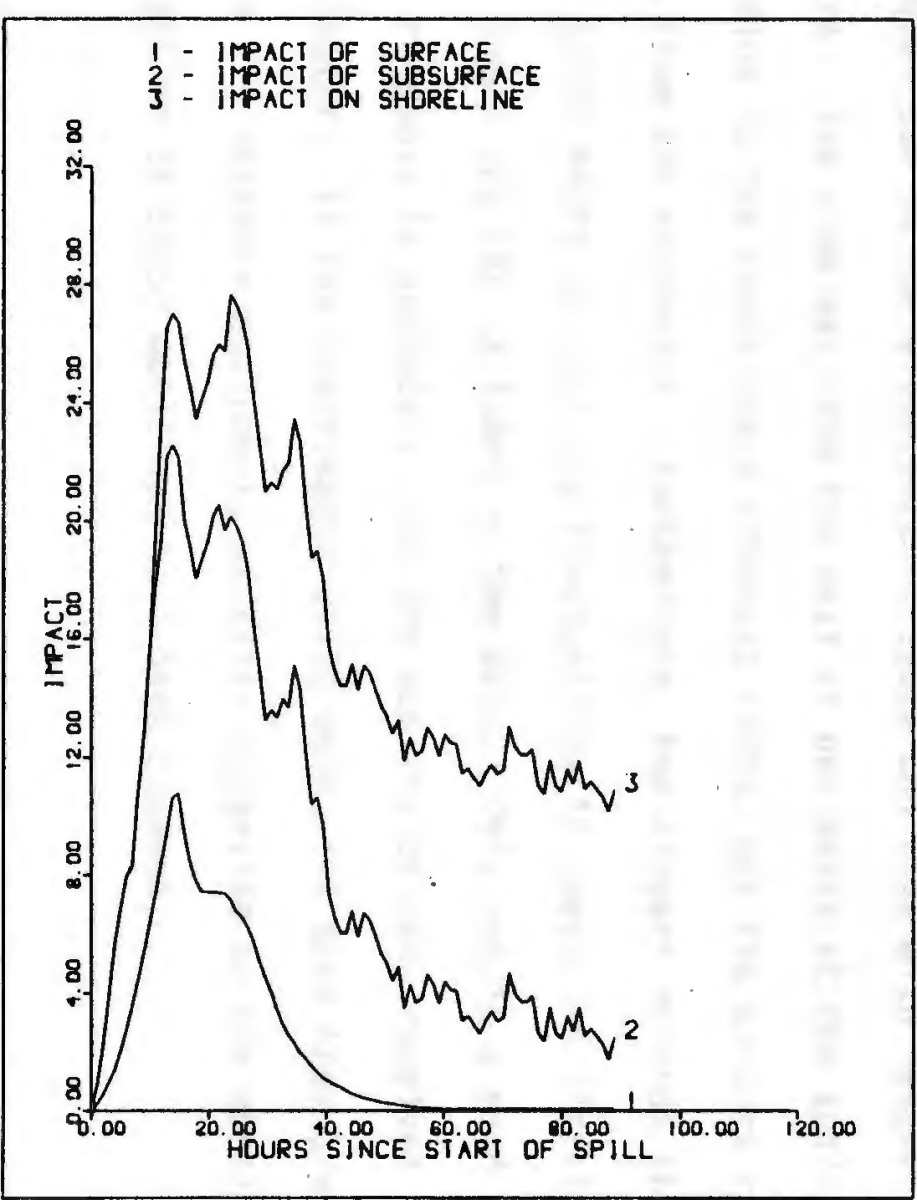

Figure 4-8 Pennant Simulation Impact 
not predict it. The wind record used in the simulation may also be erroneous due to the difference of space and time with respect to Green Airport. The wind was from the east at one point at the spill site according to the Coast Guard (Pennant 1973), but the airport recorded winds from the southeast. Furthermore, the airport records the wind every three hours so that any fluctuations in speed and direction between these times are not included in the data. This run is a good example of how a response is dependent upon the quality of data received by the coordinator. If the coordinator using only wind data from Green Airport, placed his response equipment, at sites suggested by the model, at least one section of coast would not have been covered.

The two spills simulated above indicate that within the limitations of the environmental data the model does a reasonable job of predicting the behavior of oil in coastal waters. It provides new insight for researchers who are trying to determine the affect of oil on subsurface organisms. The program can also supply information for personnel responsible for planning and implementing cleanup strategies. The next section will give some simple examples which use the response section of the model and the training aspects which have been integrated into it.

\section{Training Application}

A simple simulation has been set up for upper Narragansett Bay to demonstrate the model's capabilities. This simulation is a 50 ton spill 
(12,500 gallons) of number 2 fuel oil on January 2, 1977 and is represented by one spillet. The wind for the first $41 / 2$ days is shown in Figure 4-9 and the predicted winds are in Table 4-4. The predictions for days 1,2 and 4 are in general agreement with the actual winds, however, the third day is off due to a wind shift during the middle of the day. This is the same type of predicted data an on-scene coordinator would get from a local weather bureau and the information which is passed to the user in this program. A student using the program for training will initially not see the actual winds that the model uses.

Maps of the spill without any response are shown in Figure 4-10 every 5.9 hours. The subsurface contours represent a concentration of 10 parts per billion. A drift angle of twenty degrees was used. I.t can be seen that the wind blows the spillet south for the first 24 hours and then moves it north with the help of some current. At about the 34 hour mark, it is moved south again along the shore and then is pushed slowly towards the northwest of $f$ the coast until the wind shifts and it comes ashore a third time. The mass balance and impact of this spill is shown in Figures 4-11 and 4-12. The majority of the oil is beached in the first eight hours and between 28 to 32 hours after the start. The subsurface ceases to be significant after about 28 hours although it dominates for the first 20 hours.

The simulation was repeated with two different cleanup responses. Summaries of these responses are shown in Table 4-5. The responses are typical of what a coordinator would execute. The first one includes two 


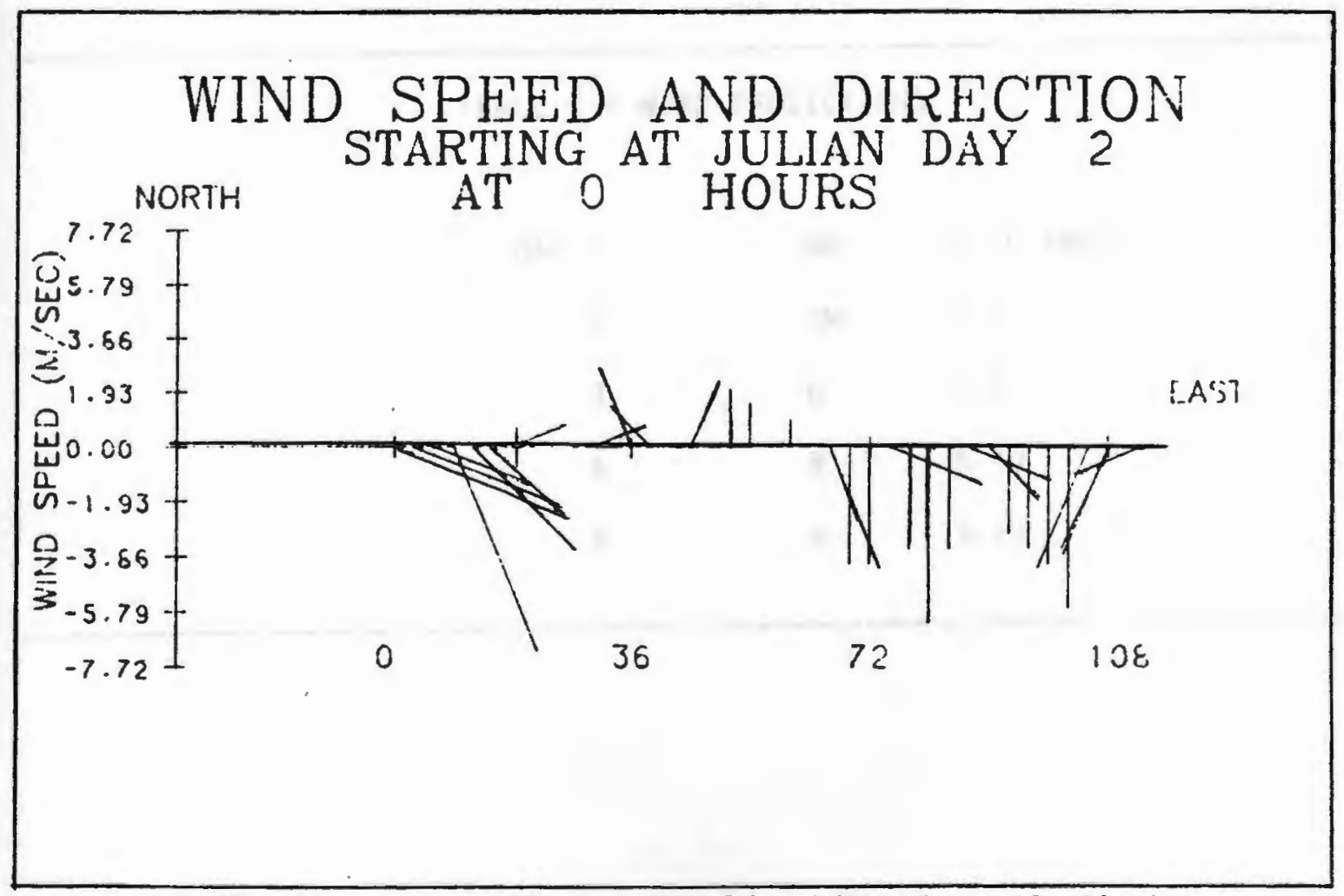

Figure 4-9 Narragansett Bay Application Actual Winds 
TABLE 4-4 WIND PREOICTIONS

$\begin{array}{ccc}\text { DAY } 1 & \text { NW } & 5-10 \text { KNOTS } \\ 2 & \text { SW } & 0-5 \\ 3 & \text { W } & 0-5 \\ 4 & \text { N } & 5-10 \\ 5 & \text { N } & 5-10\end{array}$


5.9 HOURS AFTER START OF THE SPILL MAP OF SPILLETS AND SUBSURFACE

占

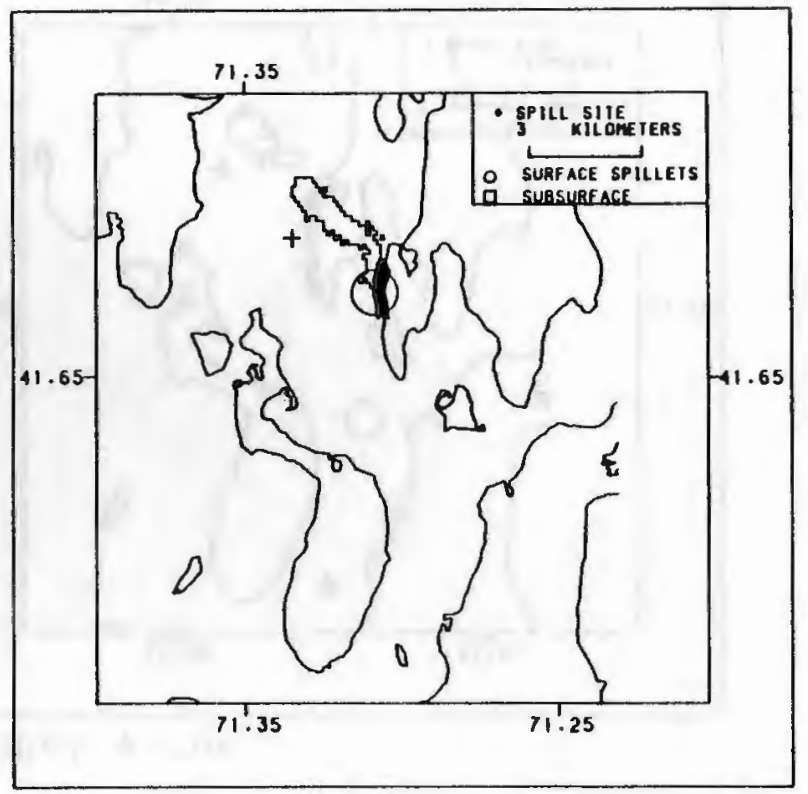

Figure 4-10a
11.8 HOURS AFTER START OF THE SPILL MAP OF SPILLETS AND SUBSURFACE

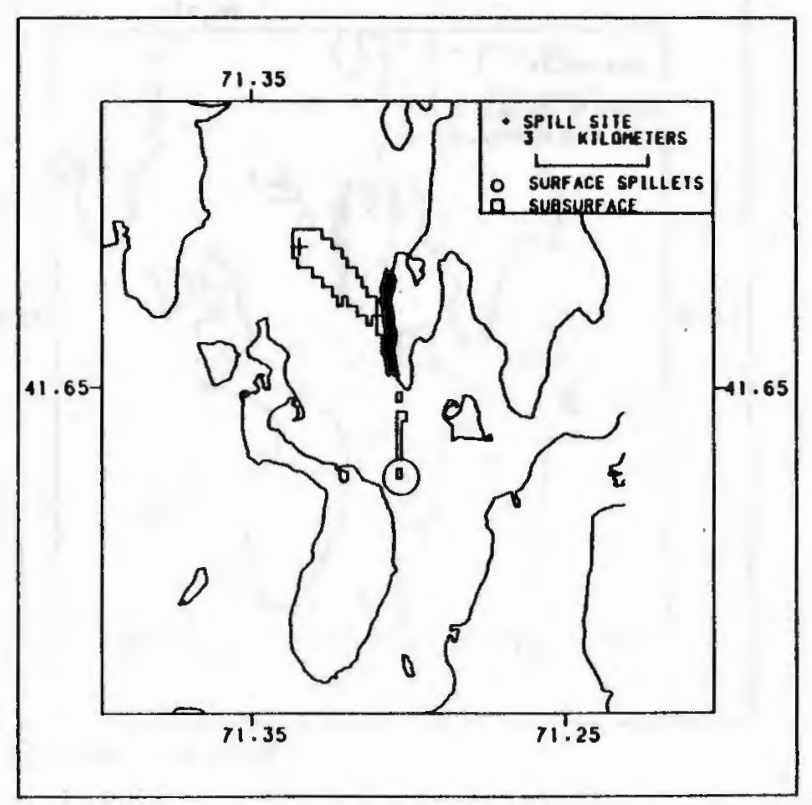

Figure 4-10b

Figure 4-10 0il Locations for Narragansett Bay Applications 
17.8 HOURS AFTER START OF THE SPILL MAP OF SPILLETS AND SUBSURFACE

๖ำ

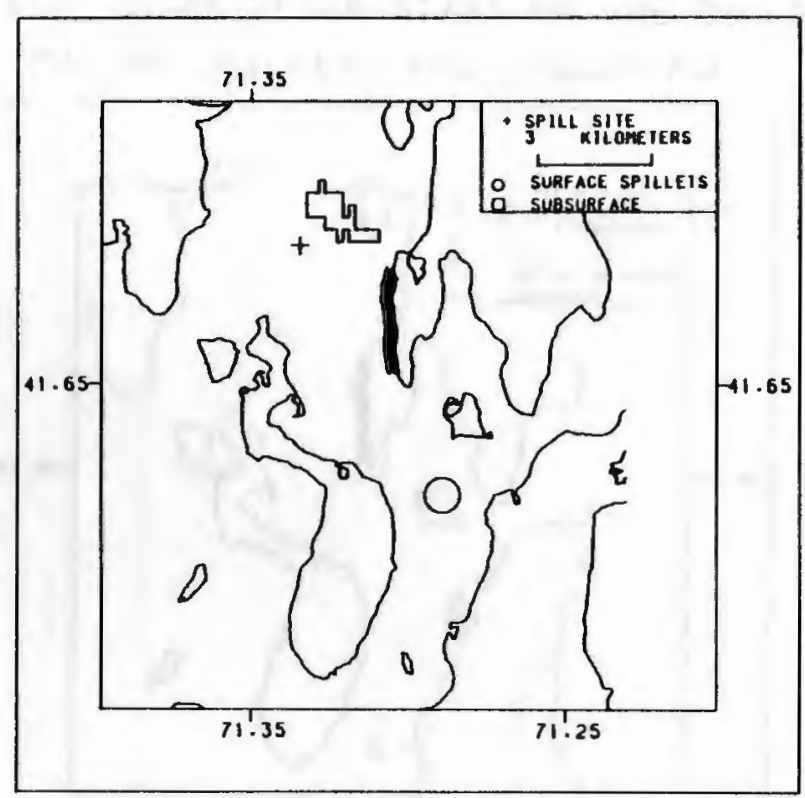

Figuer 4-10c
23.7 HOURS AFTER START OF THE SPILL MAP OF SPILLETS AND SUBSURFACE

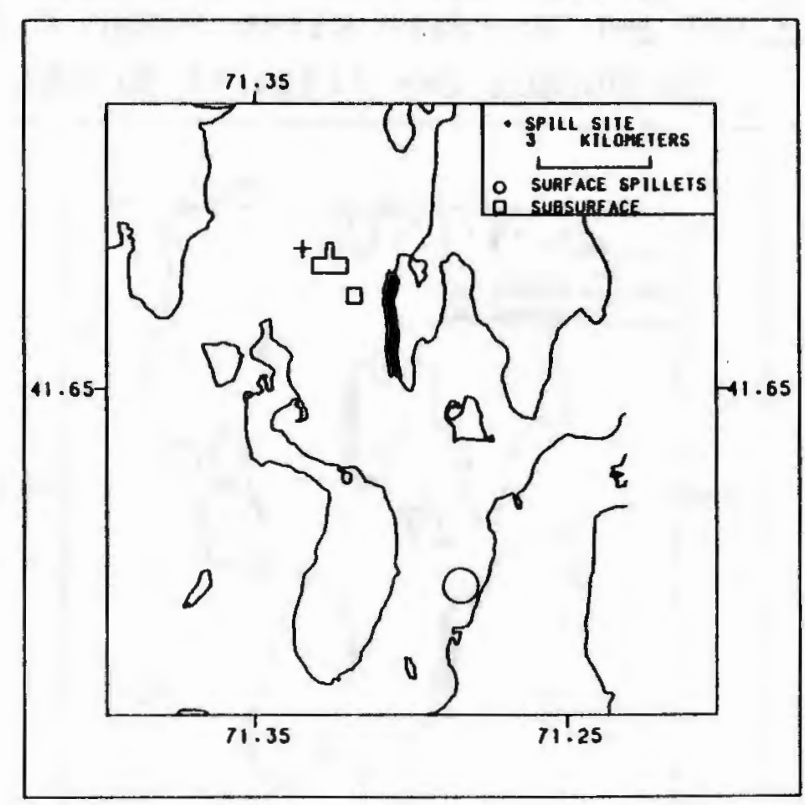

Fịgure 4-10d 
29.6 HOURS AFTER START OF THE SPILL MAP OF SPILLETS AND SUBSURFACE

○

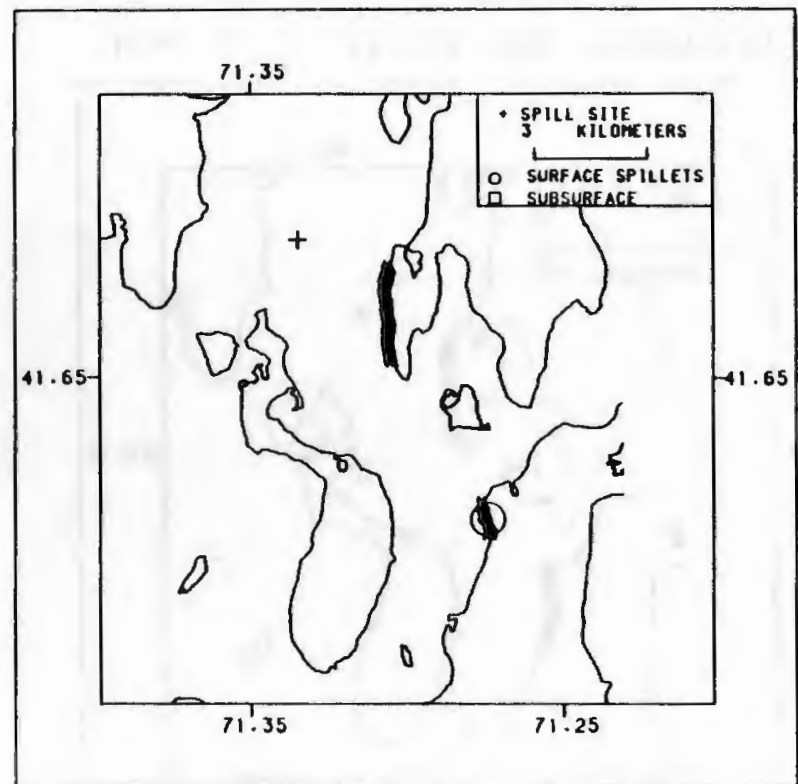

Figure 4-10e
35.5 HOURS AFTER START OF THE SPILL MAP OF SPILLETS AND SUBSURFACE

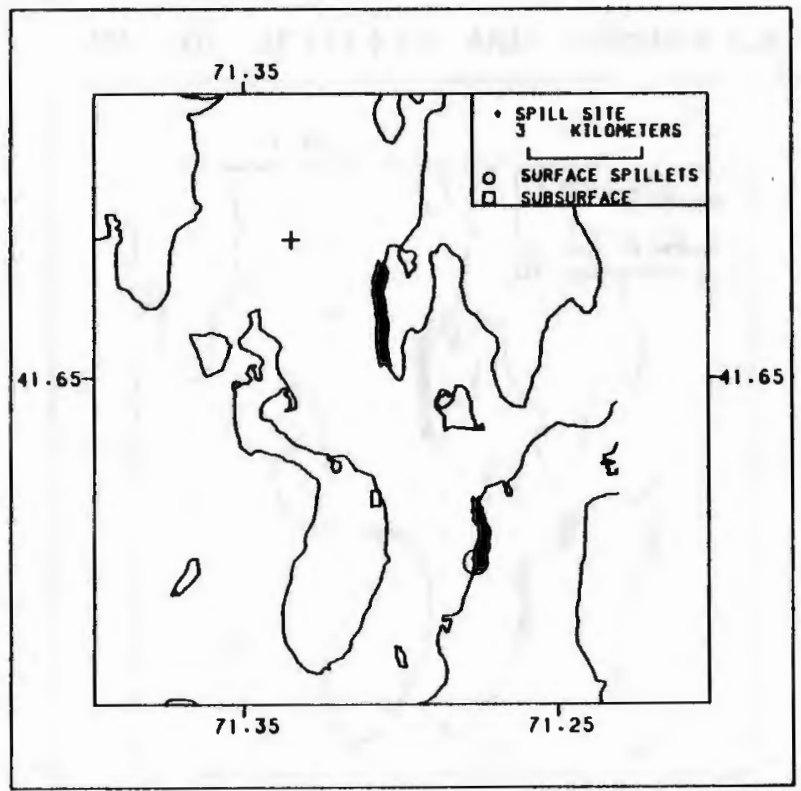

Figure 4-10f 
41.4 HOURS AFIER START OF THE SPILL MAP OF SPILLETS AND SUBSURFACE

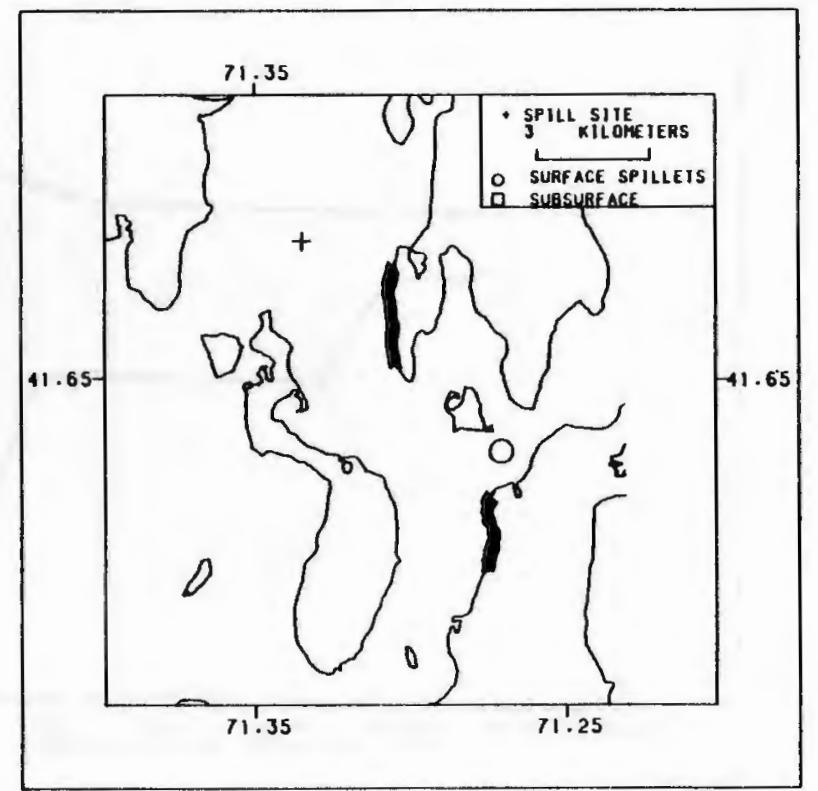

Figure 4-10g
47.4 HOURS AFTER START OF THE SPILL MAP OF SPILLETS AND SUBSURFACE

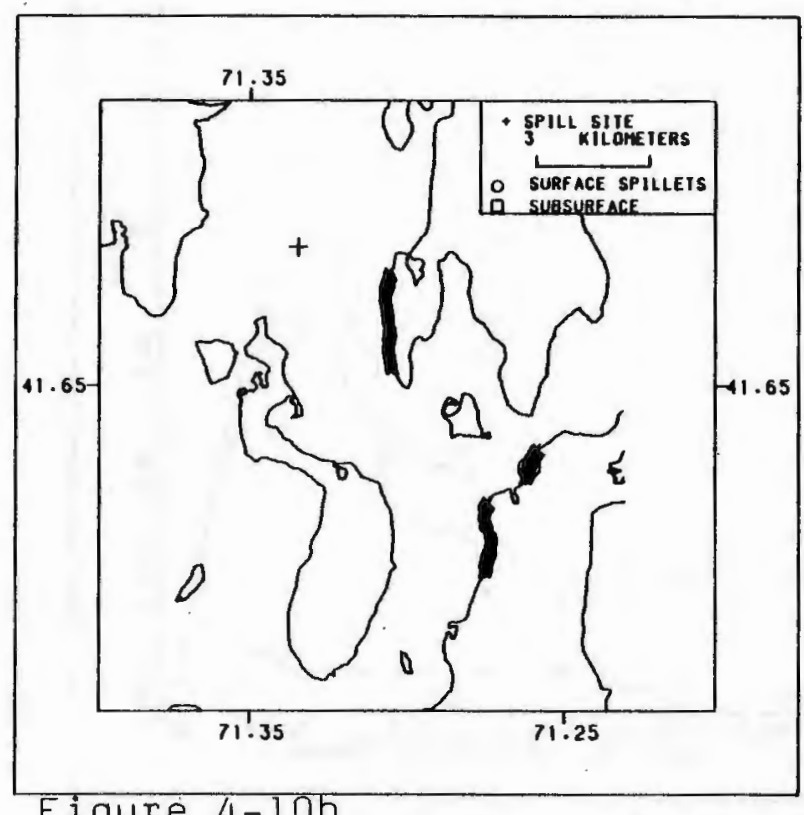

Figure 4-10h 


\section{MASS DISTRIBUTION}

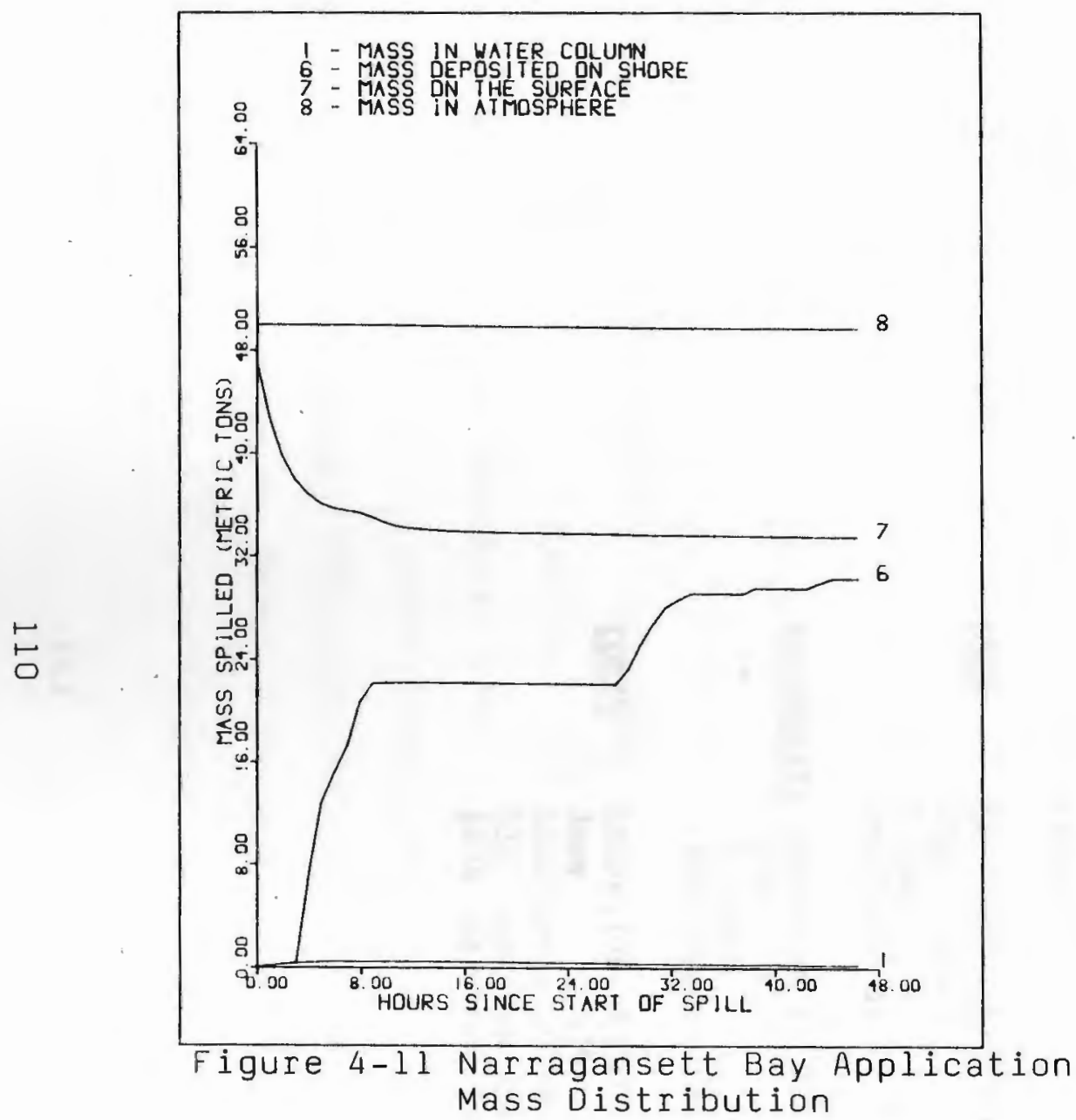

IMPACT DF SPILL

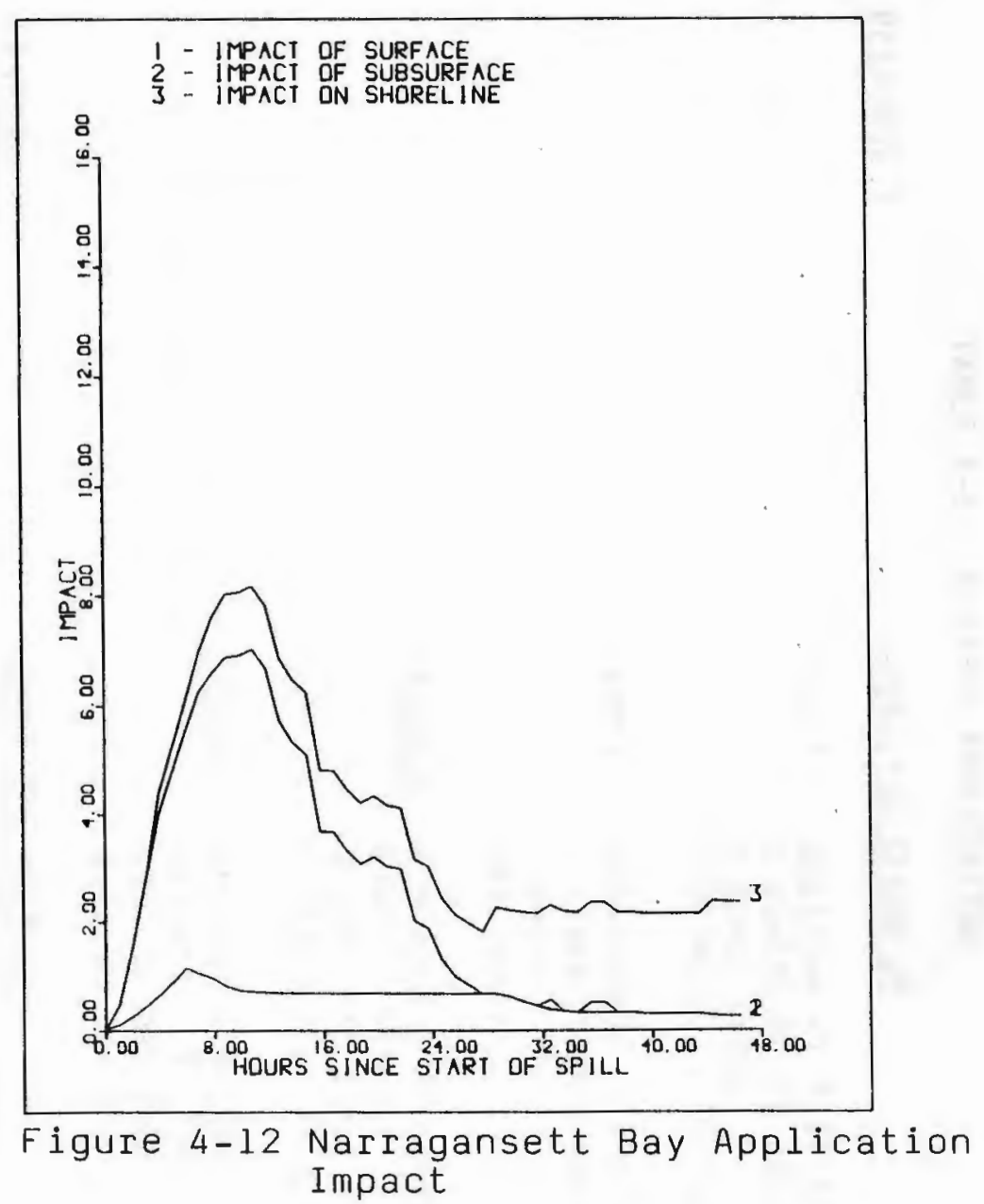


MASS DISTRIBUTION

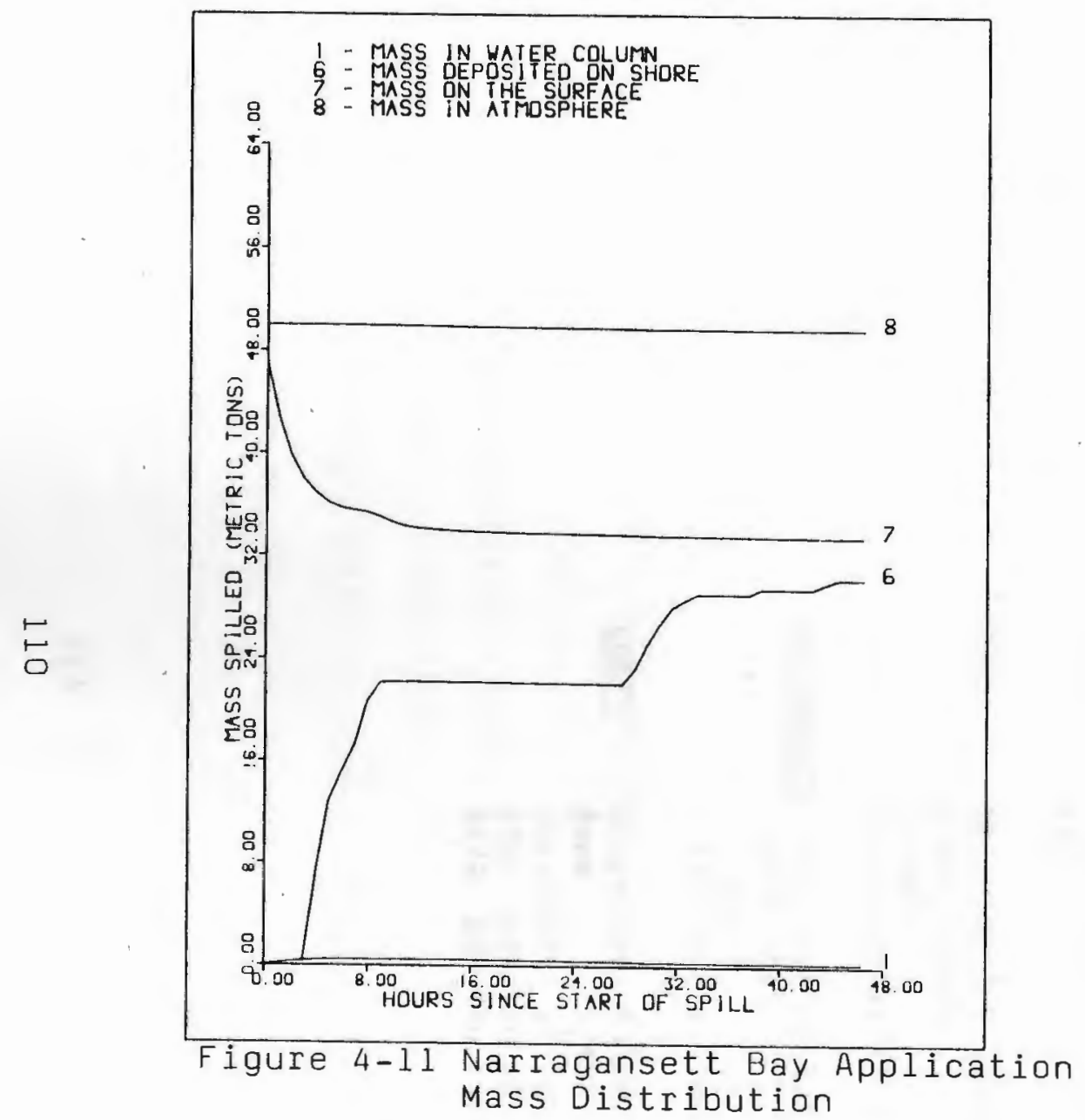

IMPACT OF SPILL

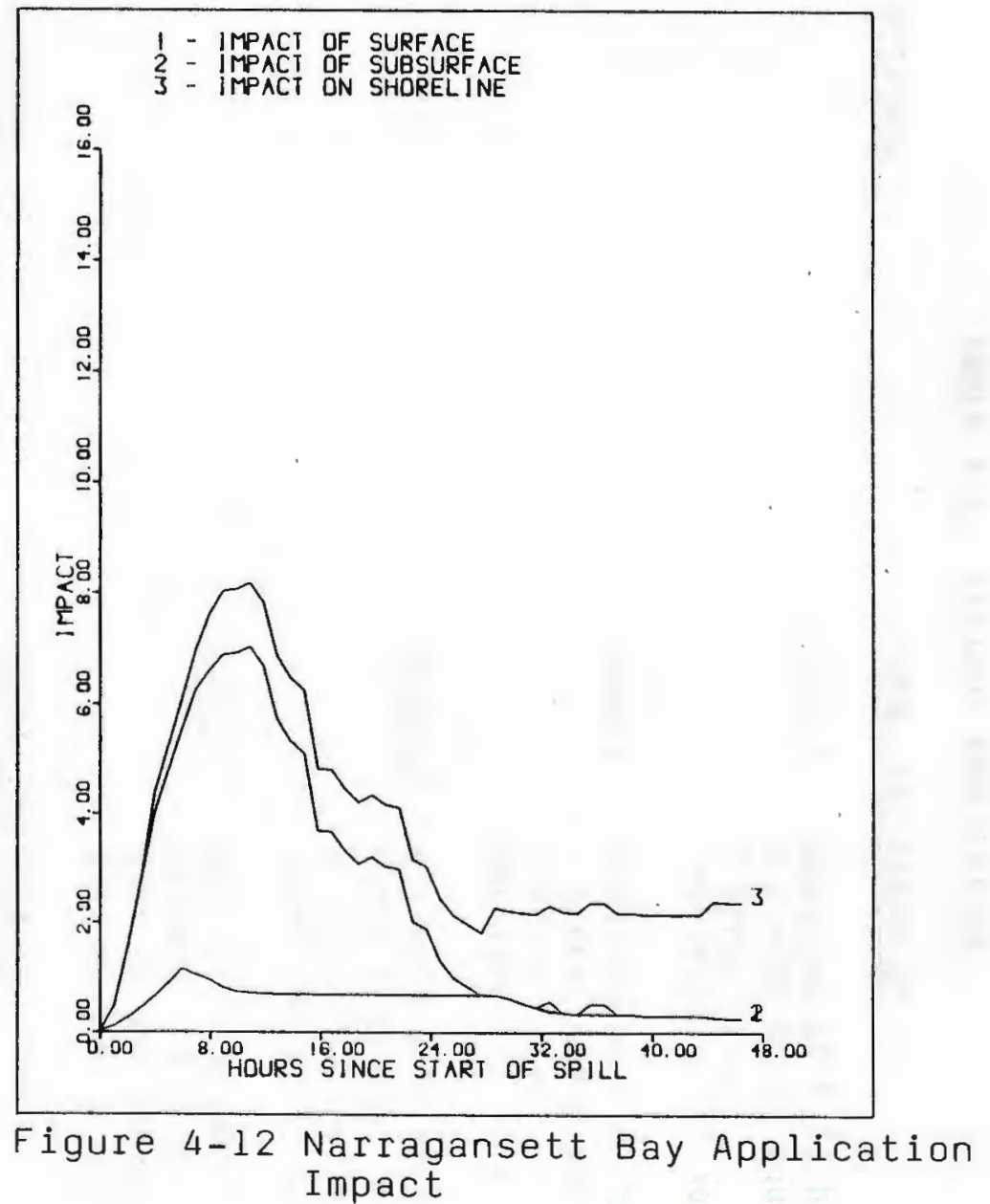


TABLE 4-5. CLEANUP APPLICATION

RESPONSE 1

RESPONSE 2

\section{SHORELINE CLEAN UP}

Team 1 deployed at 6.22 hours

3 pieces heavy equipment.

3 spray crews

retrieved at 40 hours

Team 2 deployed at 6.83 hours

3 pieces heavy equipment

3 spray crews

retrieval at 11.4 hours

SKIMMER deployed 6.35 hours

class 1 skimmer

3 tons per times step retrieved at 11.8 hours

COSTS shoreline $\$ 4,900$.

skimmer \$ 150.

$\$ 101.50$ per ton spilled

$\$ 142.90$ per ton cleaned up

SHORELINE CLEANUP

same as response 1 -

retrieved at different

times

BOOM

deployed 3.47 hours

Class 1 boom

2 boats

retrieved at 17.7 hours

ABSORBENTS deployed at 4.9 hours 2000 lbs.

2 boats

finished at 18.2 hours

COSTS Shoreline $\$ 5500$.

Boom \$2450.

Absorbents $\$ 8150$.

$\$ 322$. per ton spilled

$\$ 474$. per ton cleaned up 
cleanup teams deployed to cover the expected stranding sites and a class one skimmer to pick up the $0 i 1$. The maps in Figure 4-13 for the first response indicate that the shoreline crews were efficient in removing the oil within about 40 hours but that the skimmer was retrieved too early and the oil allowed to come ashore elsewhere. For the second case (Figure 4-14), a boom was deployed approximately half-way down the peninsula, absorbents were used and the same shoreline cleanup teams were deployed. The boom kept the spillet from moving down the coast and allowed the cleanup teams to move into position. The absorbant cleanup method took about 8 hours longer than the skimmer but the boom helped to slow the spread. Once the oil moved past the boom, the southerly section of the peninsula was oiled and the spillet turned the corner. 0il which came ashore here was out of reach of the cleanup teams and in this simulation no additional teams were assigned. The costs in Table 4-5, reflect the increased manpower needed to handle booms and absorbents during the second response as compared to the first.

The mass balances and impacts of both responses are shown in Figures 4-15 through 4-18. In both cases, the shoreline impact is small due to the responses which are in place. Approximately the same amount of oil came ashore for both cases, 14.6 and 14.7 tons for cases 1 and 2 respectively. The skimmer cleaned up a little more and faster so that the impact was smaller. This quicker response also did not allow as much oil to enter the water column. When comparing these plots with the original run, the impact on the shoreline is reduced because the 
5.9 HOURS AFTER START OF THE SPILL MAP OF SPILLETS AND SUBSURFACE

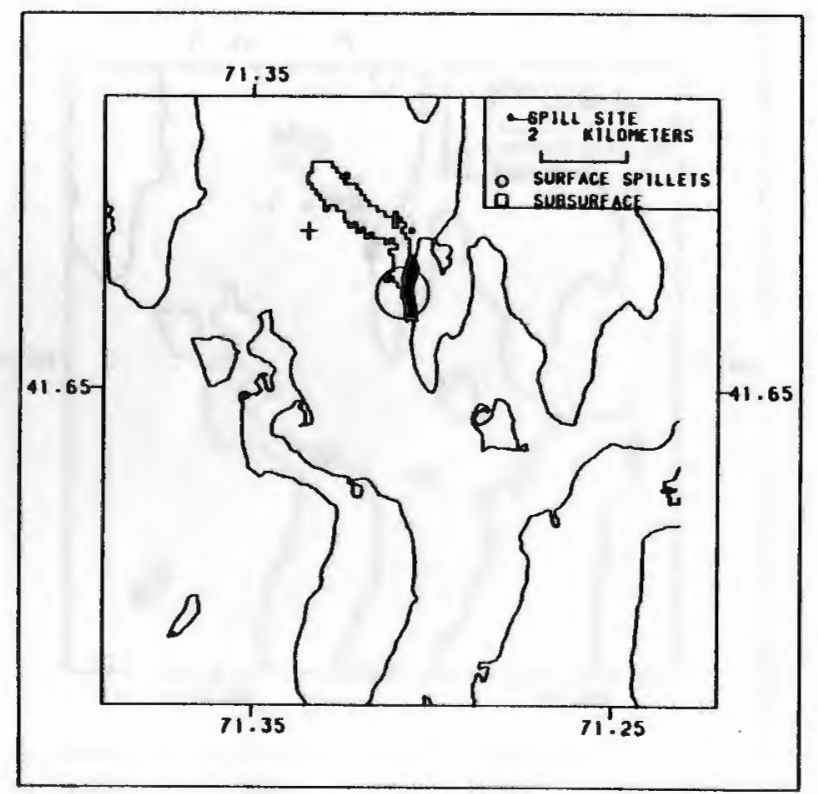

Figure 4-13a
11.8 HOURS AFTER START OF THE SPILL MAP OF SPILLETS AND SUBSURFACE

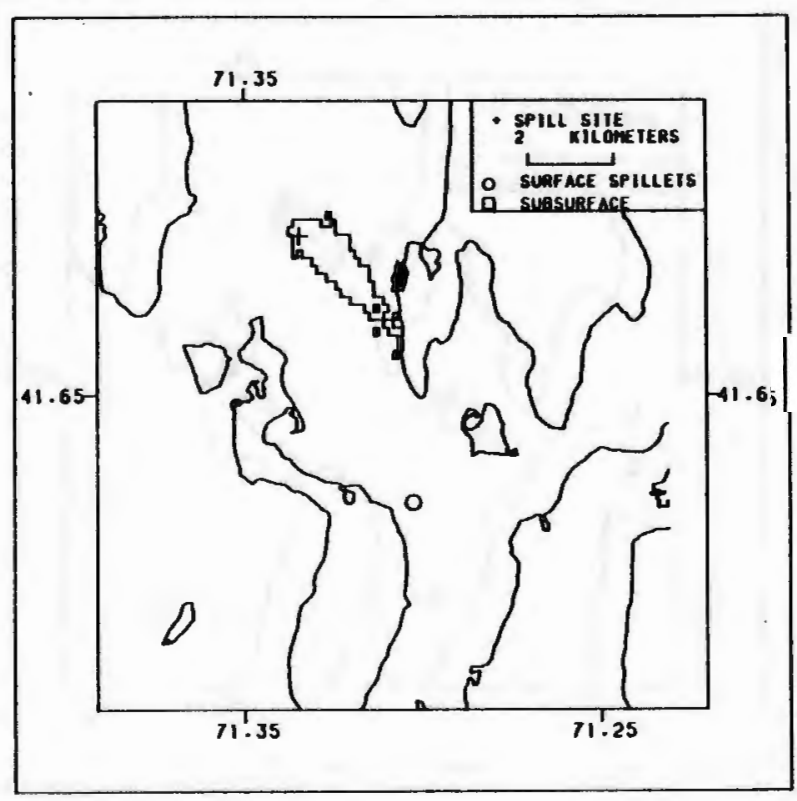

Figure 4-13b

Figure 4-13 0il Location During Response 1 
17.8 HOURS AFTER START OF THE SPILL MAP OF SPILLETS AND SUBSURFACE

$\stackrel{5}{5}$

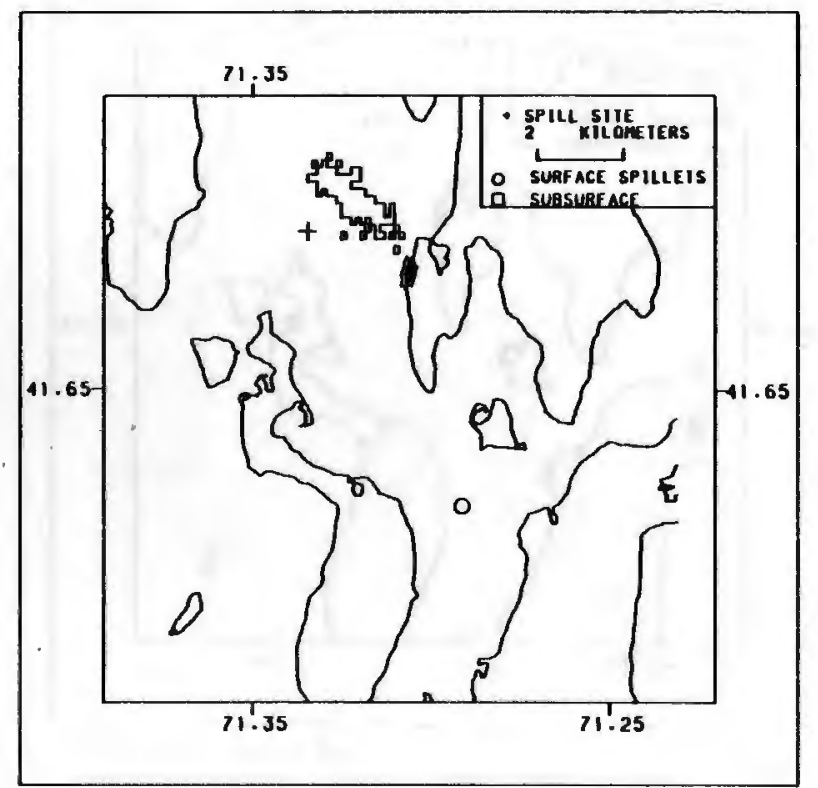

Figure 4-13c
23.7 HOURS AFTER START OF THE SPILL MAP OF SPILLETS AND SUBSURFACE

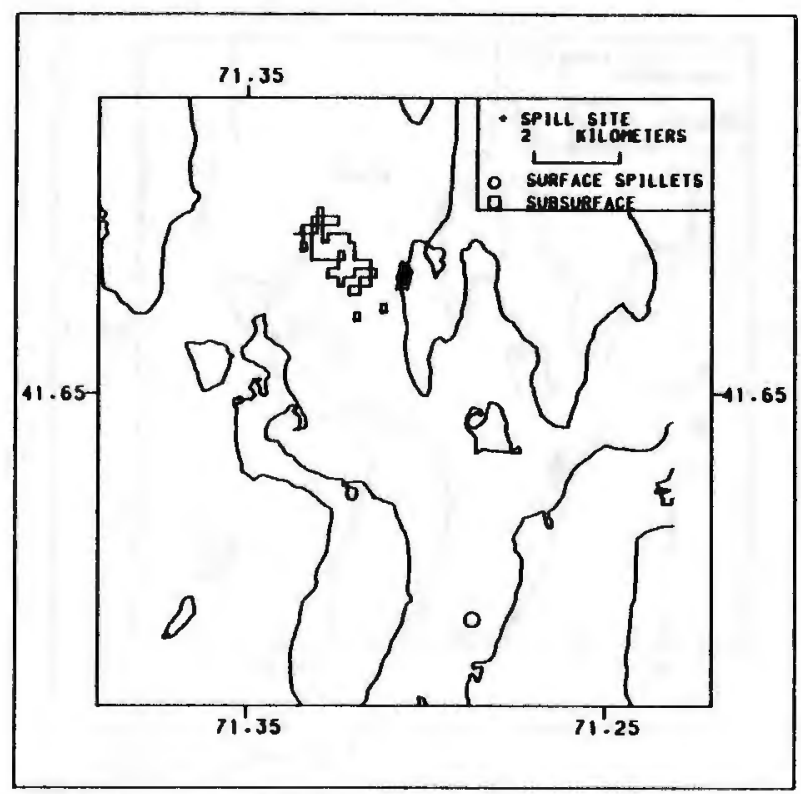

Figure 4-13d 
29.6 HOURS AFTER START OF THE SPILL MAP OF SPILLETS AND SUBSURFACE

宁
35.5 HOURS AFTER START OF THE SPILL MAP OF SPILLETS AND SUBSURFACE

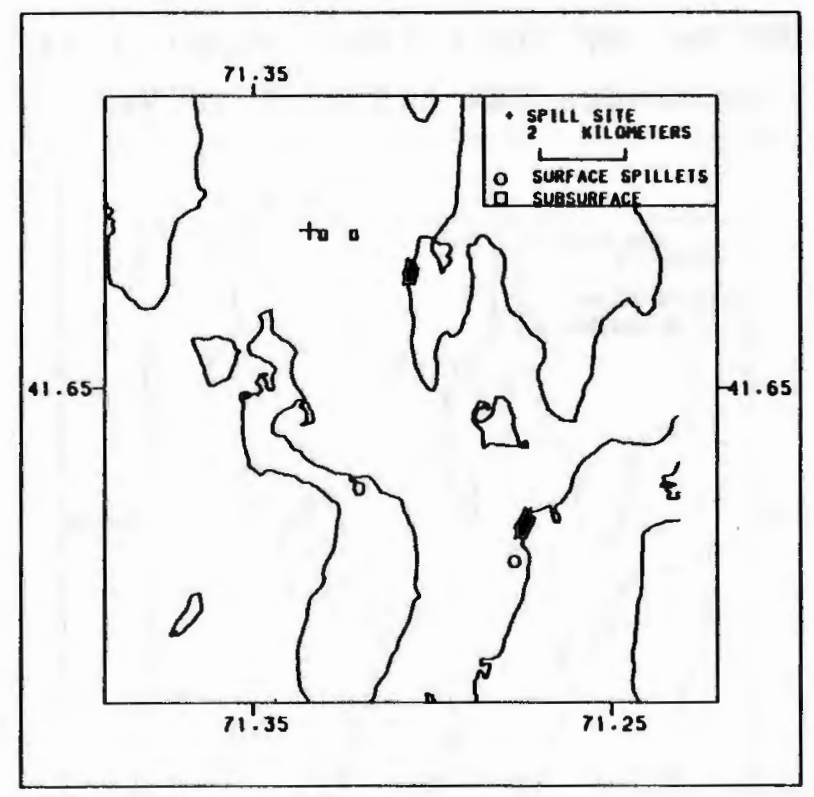

Figure 4-13f 
41.4 HOURS AFTER START OF THE SPILL MAP OF SPILLETS AND SUBSURFACE

$\stackrel{\leftarrow}{a}$

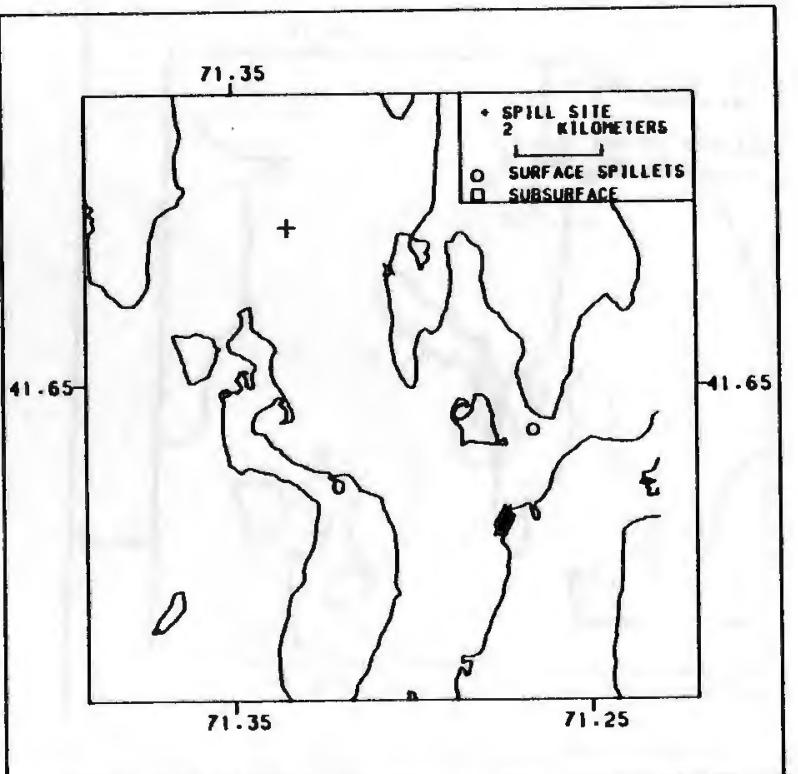

Figure 4-13g
47.4 HOURS AFTER START OF THE SPILL MAP OF SPILLETS AND SUBSURFACE

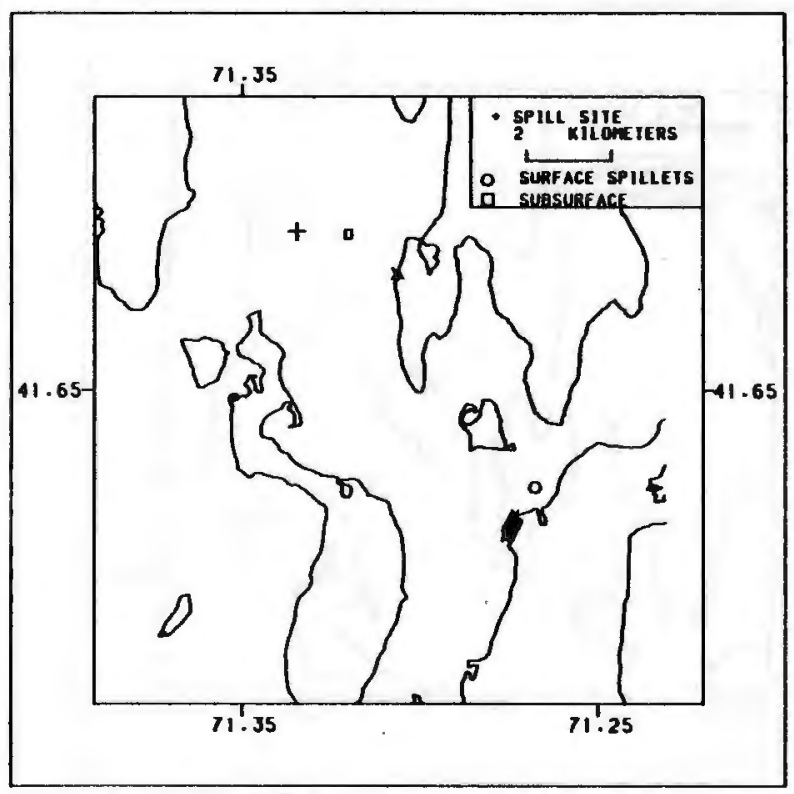

Figure 4-13h 
5.9 HOURS AFTER START OF THE SPILL MAP OF SPILLETS AND SUBSURFACE

$\stackrel{5}{5}$

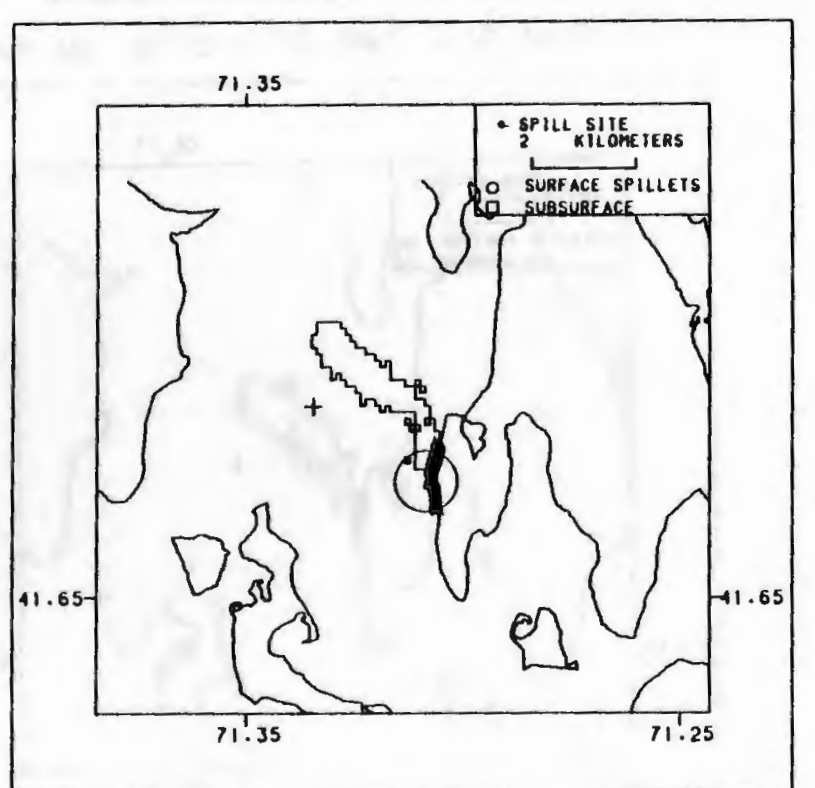

Figure 4-14a
11.8 HOURS AFTER START OF THE SPILL MAP OF SPILLETS AND SUBSURFACE

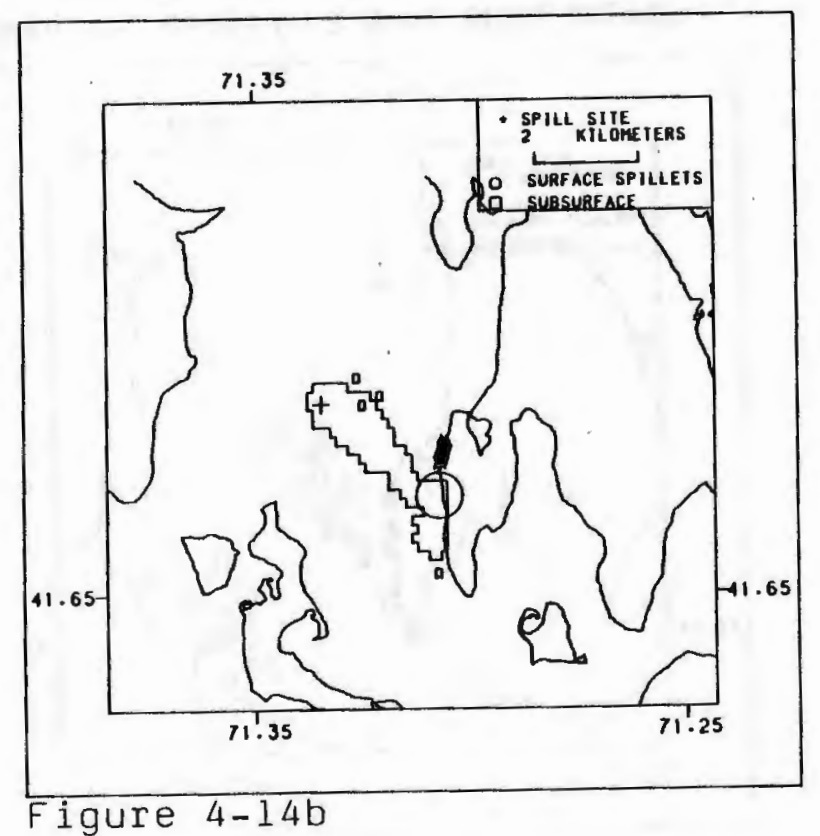

Figure 4-14 Dil Locations During Response 2 
17.8 HOURS AFTER START OF THE SPILL MAP OF SPILLETS AND SUBSURFACE

$\stackrel{5}{\infty}$

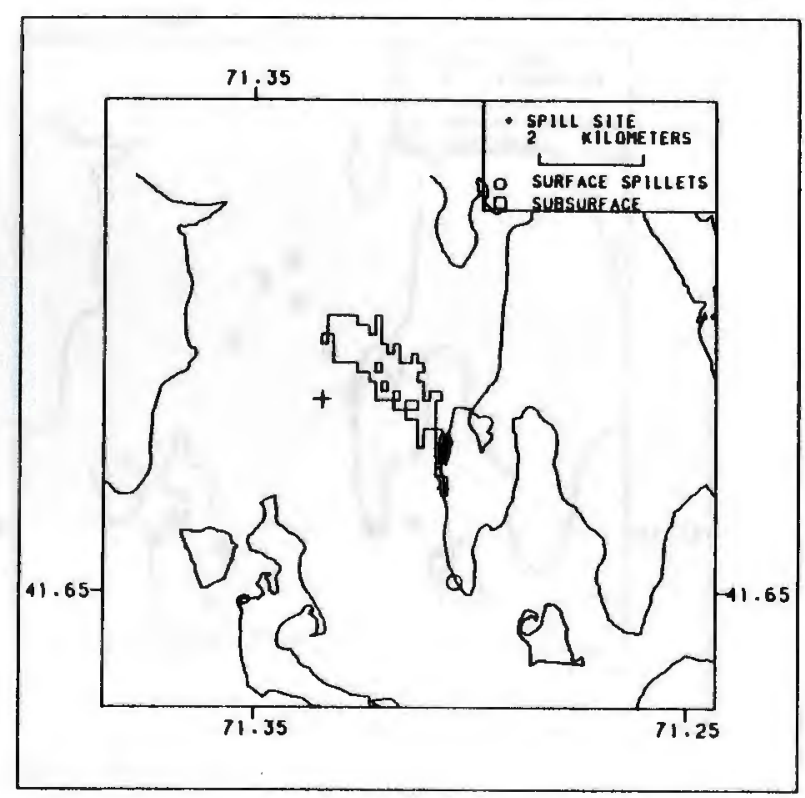

Figure 4-14c
23.7 HOURS AFTER START OF THE SPILL MAP OF SPILLETS AND SUBSURFACE

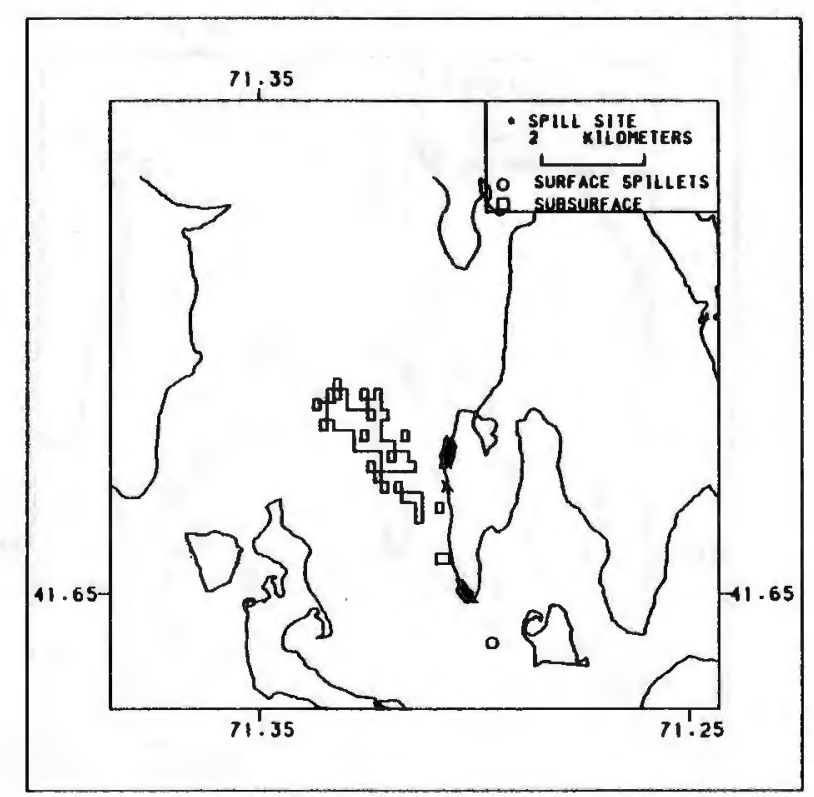

Figure 4-14d 
29.6 HOURS AFTER START OF THE SPILL MAP OF SPILLETS AND SUBSURFACE

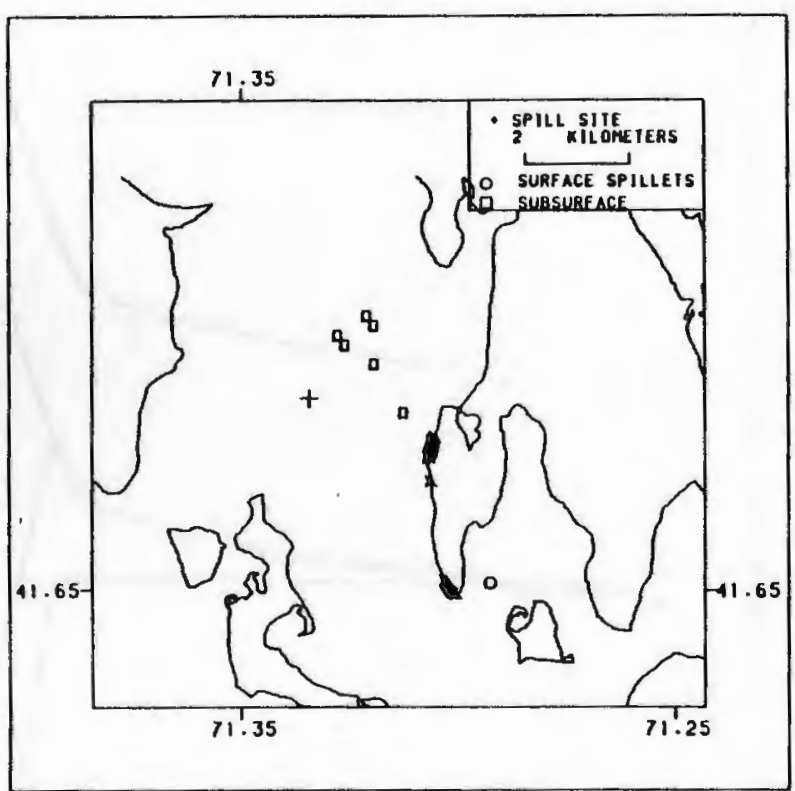

Figure 4-14e
35.5 HOURS AFTER START OF THE SPILL MAP OF SPILLETS AND SUBSURFACE

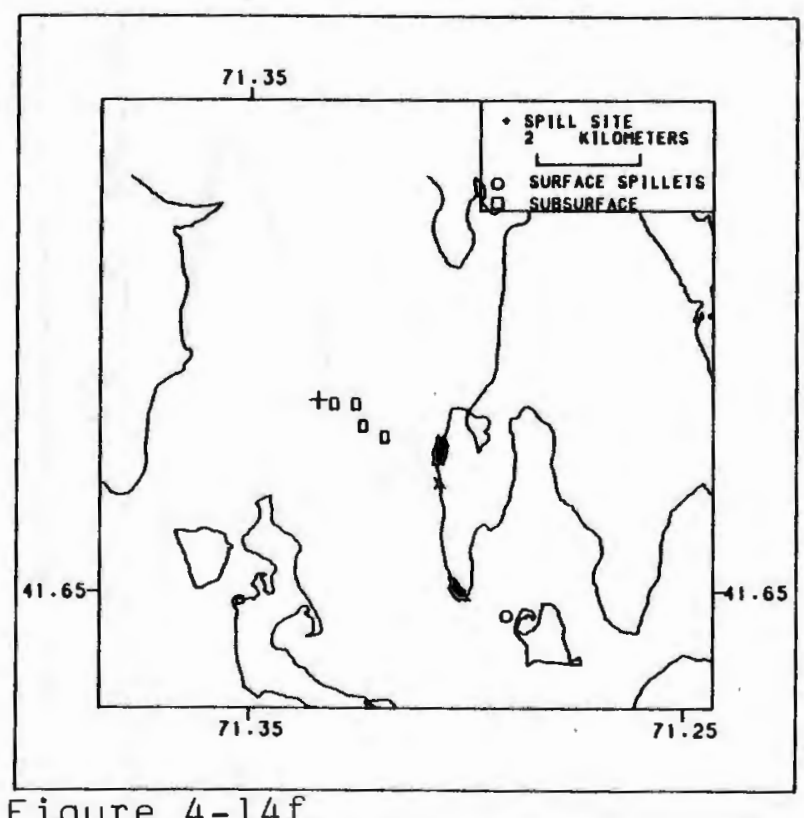


MASS DISTRIBUTION

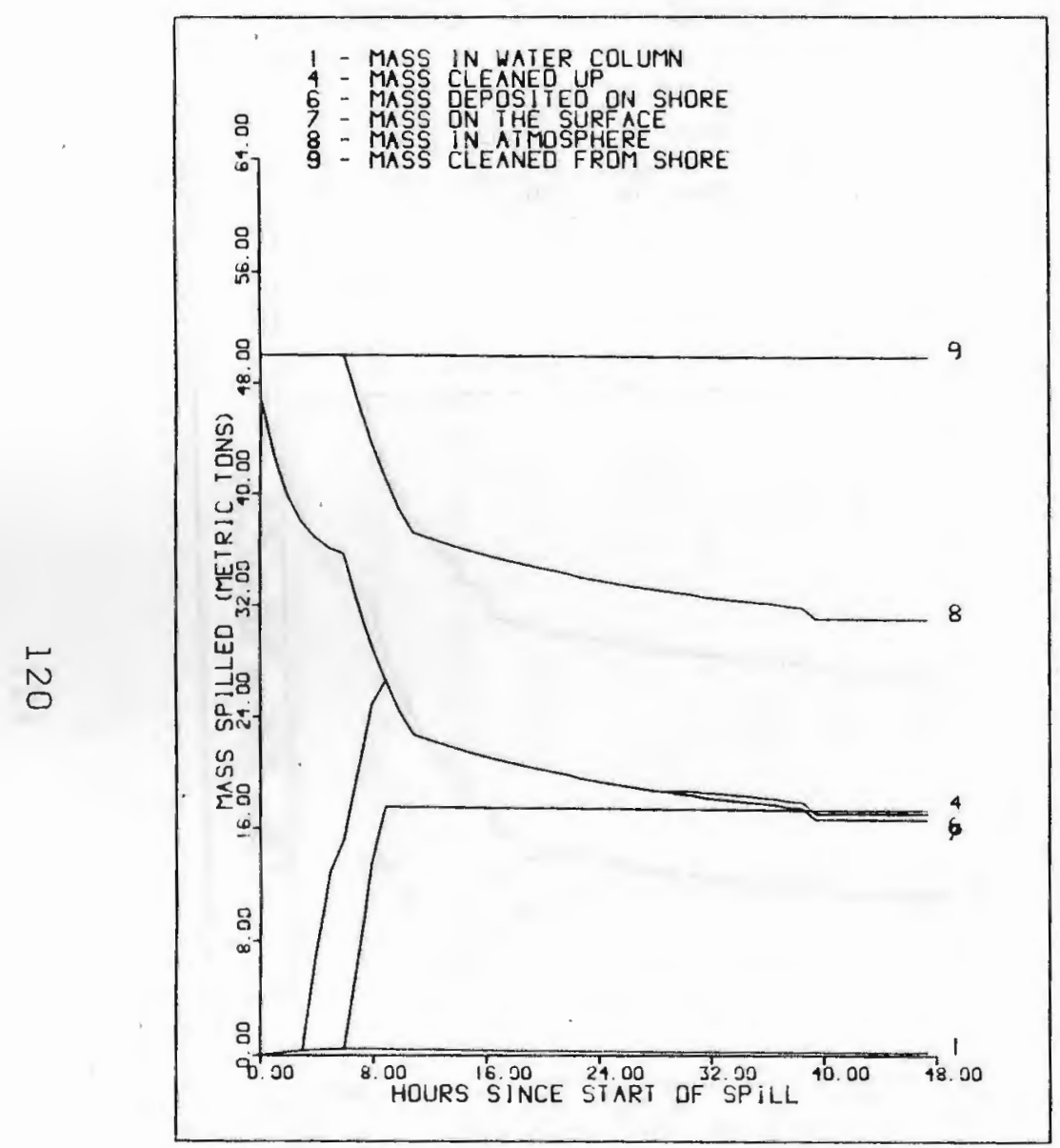

Figure 4-15 Mass Balance for Response 1
IMPACT OF SPILL

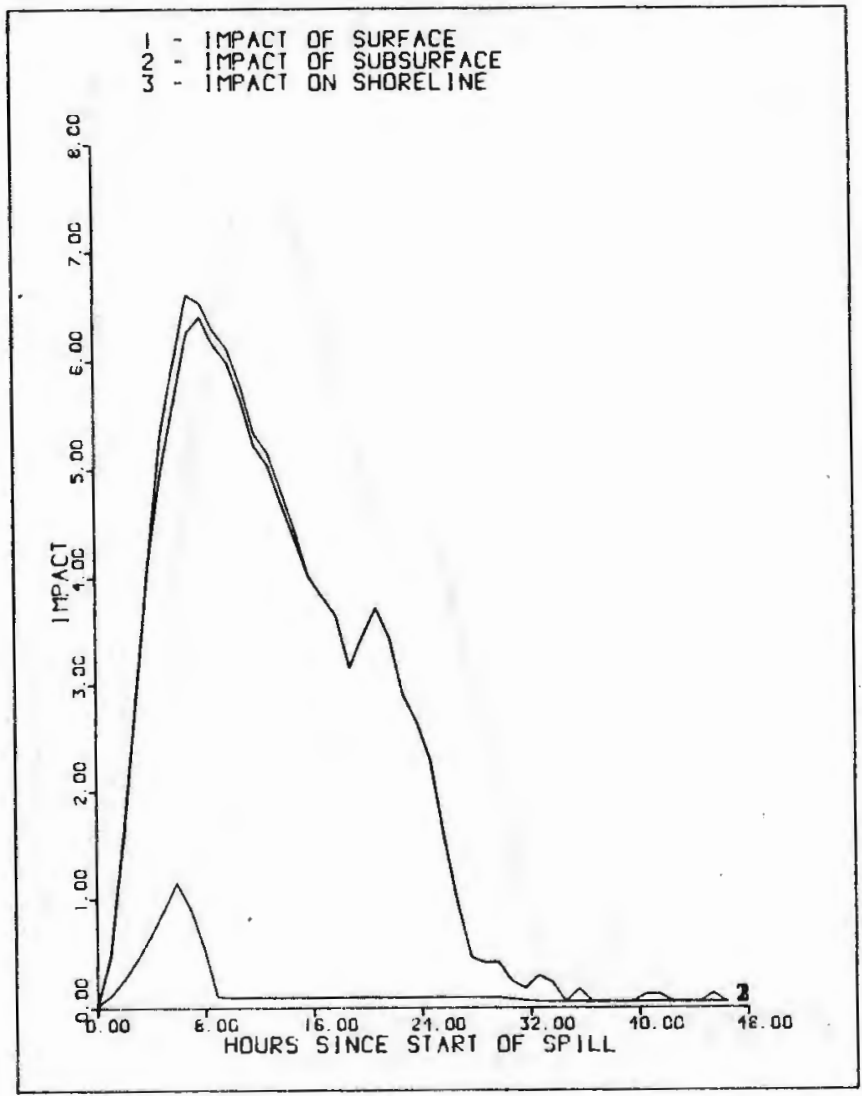

Figure 4-16 Impact for Response 1 


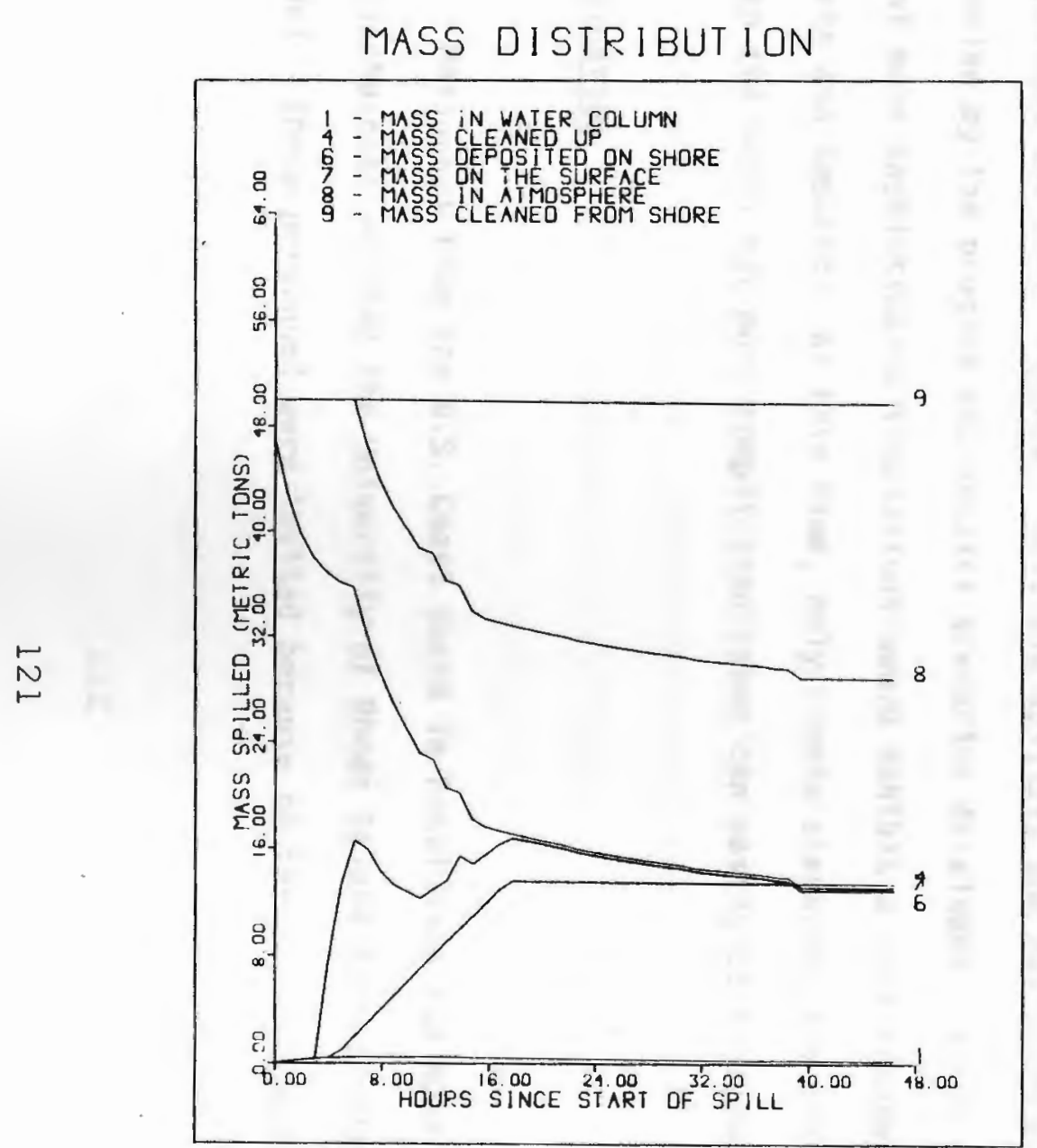

Figure 4-17 Mass Balance for Response 2
IMPACT OF SPILL

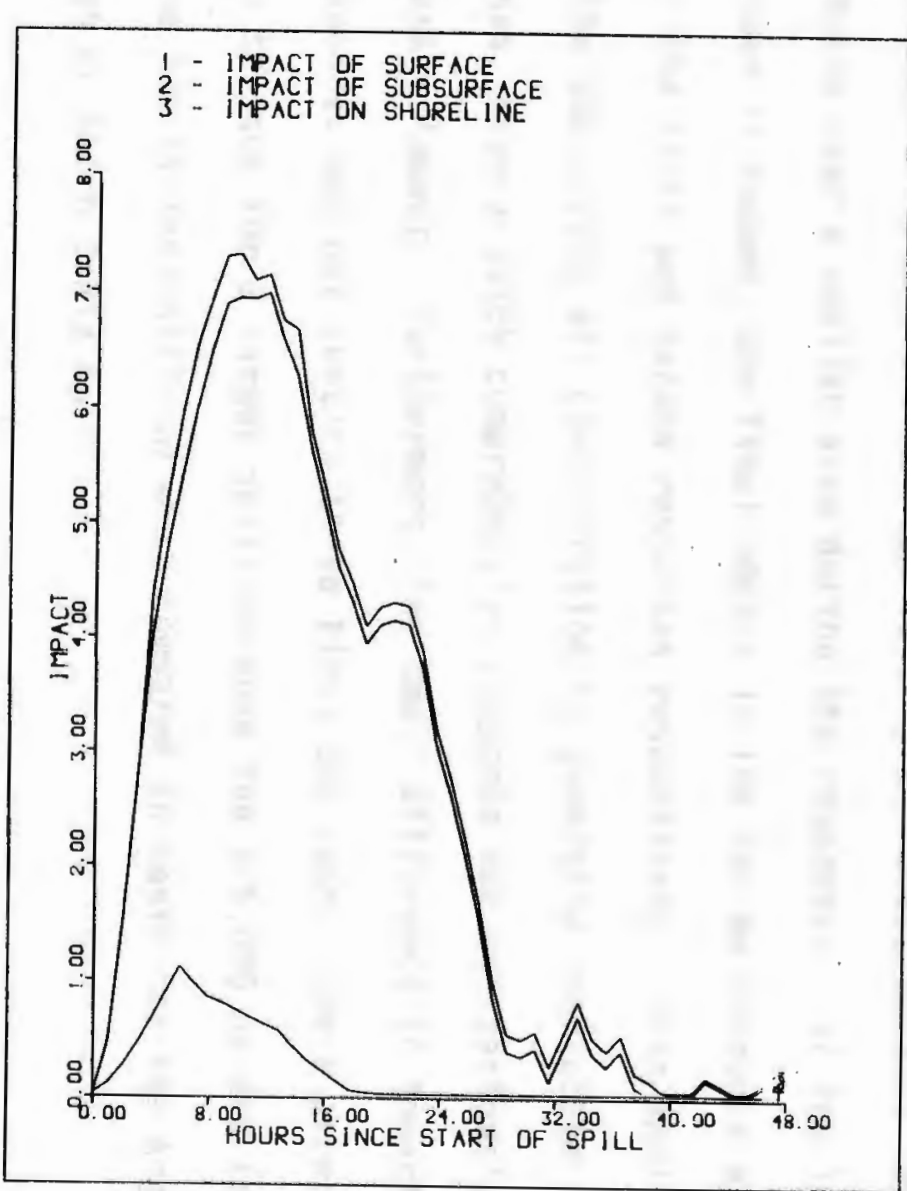

Figure 4-18 Impact Plot for Response 2 
responses do not allow oil to reach the coastlines farther down the bay. The subsurface impacts are not appreciably different because less oil is distributed over a smaller area during the responses. If the impact at every hour is summed, the final impact is 165 for no response and 133 and 115 for the first and second responses respectively. This indicates that since the subsurface ofl concentration is generally unaffected by the responses, even a quick comprehensive response may not seriously affect the overall impact. Furthermore, the small difference in impact between the responses may not justify three times the cost. These aspects would be more serious for a larger spill because the $\$ 16,000$ needed for response two is insignificant when compared to costs for the Argo Merchant or Amoco Cadiz Spill.

The above application is a simple case and does not necessarily represent the best response. Multiple spillets and responses can be handled by the program and complex scenarios developed. It is expected that more sophisticated simulations would exhibit a much broader range of costs and impacts. At this time, only simple scenarios are programed into the model but more complicated cases can easily be included.

\section{Evaluation}

Personnel from the U.S. Coast Guard in Providence and NOAA from Massachusetts visited the University of Rhode Island to evaluate the mode1. These personnel were invited because of the present methods used 
in their organizations to predict oil movement and coordinate response. The Coast Guard in Providence supplies the on-scene coordinator for any open water in Rhode Island. Personnel are trained at a facllity in Yorktown, Virginia but become familiar with the local area by on-the-job training. To determine oil trajectories, the NOAA field office in Massachusetts collects the needed information and telephones a facility in Seattle, Washington. This facility runs computer programs to predict oil movement and returns the results by telephone.

Both individuals agreed that the model is useful as a training tool and to predict real-time trajectories since no comprehensive methods are available. After trying the program for a short time, it was determined that clarification is needed concerning some of the questions and answers which are used by the model. It was pointed out that a student who ran the programs several times would become familiar with the questions and anticipate the answers. Another recommendation was to include a coast Guard requirement of computing costs daily. This can be easily included in a future version of the model. One drawback cited was that the program was slow and needed to respond more quickly. Overall, the evaluators were enthusiastic about the format and options of the model. The comments from the evaluators are contained in the Appendix $D$. 


\section{CHAPTER V}

CONCLUSIONS

An interactive computer model for training spill response personnel has been developed. It utilizes state-of-the-art modeling techniques for the known physical and chemical processes which are important in a nearshore environment. Unlike most other models it has the ability to track oil on the surface and within the water column. The program also contains a simple coastline interaction routine which simulates the movement of oil along a shoreline. Response procedures which allow a user to control and clean up the oil have been developed and incorporated into the program. The model has the ability to calculate the relative impact of oil on a region. The effectiveness and cost of one spill response can be compared to another to determine the relative efficiency of the response methods chosen. The program is modular so that any advances in research or modeling techniques can be easily included in the future.

The main program has been integrated with routines to control the input and output data. The input routines access a data base for a region and transfers the appropriate data into the proper format for use by the main section of the model. Both the input and output routines utilize graphics which allow the user to preview data before use or examine the data which is generated by the main simulation program. The graphic routines are easy to use and can generate either interactive or hard-copy graphics. 
The model has been set up for use in the Rhode Is land coastal waters. Results from the simulation of the actual spills in Narragansett Bay indicate that the program does a reasonable job predicting oil behavior. Sample runs were performed to display the capability of the model as a training tool.

Personnel from the Coast Guard and NOAA evaluated the model and found it promising. They felt that it has more capability than any program to which they have access and that it could be easily adopted to simulate spills in other regions.

The limitations of the model indicated by the evaluators, relate to its speed and to constraints imposed by the limited space. These are both functions of the IBM computer presently being used. The University of Rhode Island uses a timesharing system which during busy times only allows a user five to ten minutes of CPU time per hour. The speed of the model becomes marginally acceptable with 15 to 20 minutes of CPU time per hour. This problem can be overcome by using a dedicated computer such as a MICROVAX.

In terms of space, the URI computer requires about 1.5 megabytes to store the main model and about 2 megabytes for the input and output programs. In addition, the model uses over twenty megabytes for storing a 11 input and output data for a 10 to 20 day simulation. This is dependent on the size of the data base created. The URI system does not 
allow one user to request this much space, so much of the data must be stored on tape which cannot be accessed during interactive execution. A dedicated system would also solve these problems.

If more speed and space can be obtained, more complex routines can be incorporated into the model. These may include more sophisticated wind and current models and shoreline interaction methods. There are additional types of equipment which could be incorporated into the model and other methods of utilizing the equipment currently included.

This model is the only interactive model to include surface and subsurface processes as well as response techniques. The program can be utilized by personnel involved with any aspect of oil spill research or training. It can transfer knowledge concerning oil spills to students more efficiently than the present methods being used. 


\section{APPENDIX A}

\section{Shoreline Interaction Routine}

The shoreline interaction routine is a simple method of simulating the movement of oil in the vicinity of the shores. Surface spillets and subsurface particles are constrained to move along the shore by responding to the onshore components of the currents and wind. The following is a brief description of the routine.

There are several assumptions made in developing this routine. First, the spillet or particle is not on land initially. The program performs some cursory chekcs but the initial spillet positions must be verified by the user. Secondly, the shoreline is digitized using longitude and latitude with dummy values between the coast and islands. This will indicate to the program that a discontinuity exists. Finally, the spillets do not interact with each other and are treated independently.

All computations performed in the subroutine are done using the computational cell grids. The shoreline positions are calculated with respect to the origin of the commutational cell grid and the spillet positions are also tracked with respect to the origin. Use of the computational cell grid speeds up the processing because the subroutine is only used when a spillet enters a land cell. 
The sequence of the routine is described below and can be followed in the flow chart in Figure A-1. After calculating the position of the spillet with respect to the computational cell grid the trajectory of the spillet's movement is determined. The initial and final positions of the spillet are then checked to see if they are in a land grid. If this is the case or this routine is being entered for the first time, the present position is stored and the next spillet is checked. The program next determines if the spillet trajectory crosses any shoreline segments or booms. The closest intersection of coastline or boom is then calculated. The three options for the program are:

1) The spillet trajectory does not cross a shoreline segment or boom so the present spillet position is stored.

2) The spillet trajectory first encounters a boom. The subroutine which simulates the boom is then called.

3) The spillet crosses a shoreline section. The spillet location is moved to the shore, then parallel to shore and finally projected out as in Figure A-2a. If the spillet reaches the end of a shoreline segment it is projected away from the coast. The subroutine 


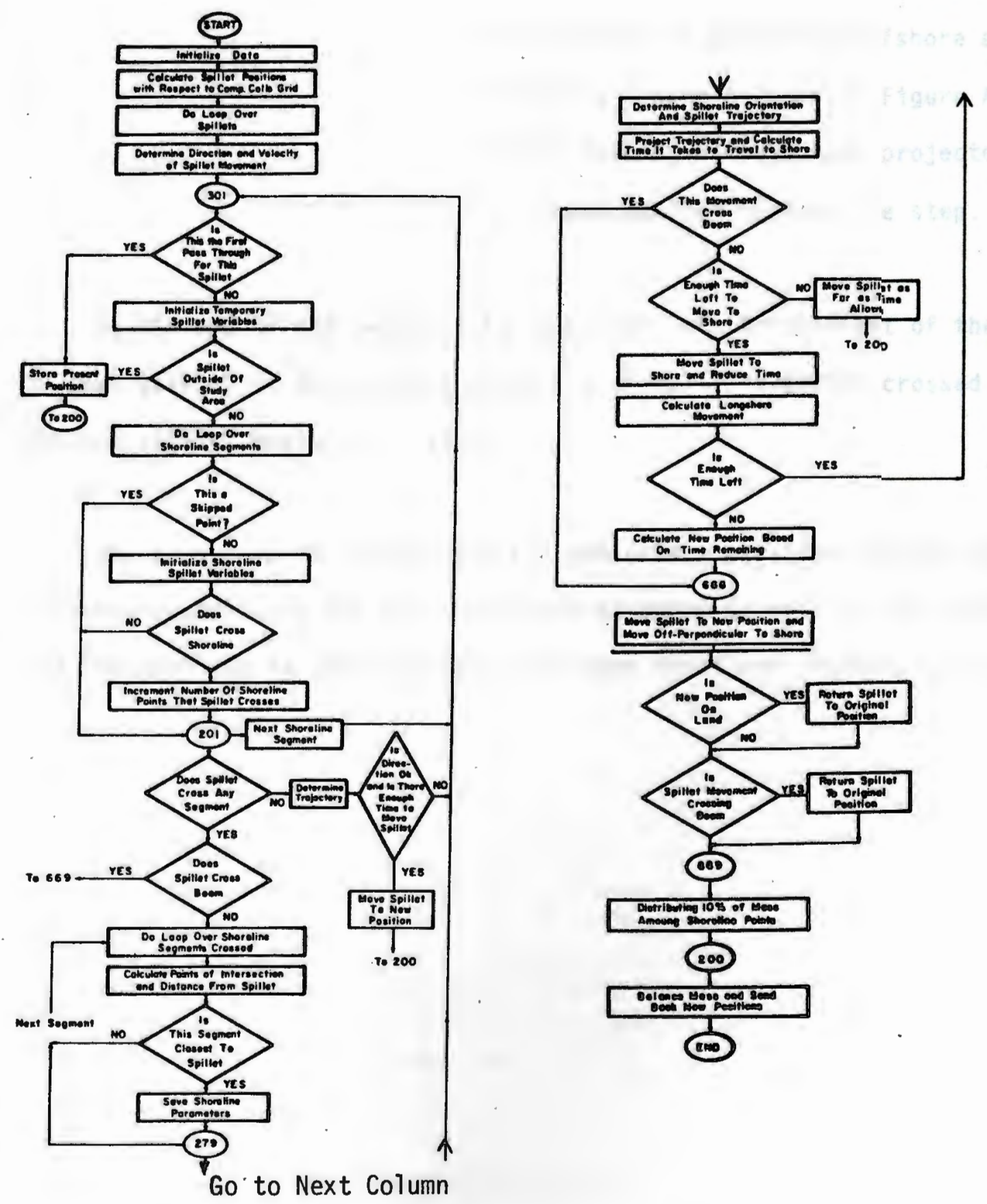

Figure A-1 Shoreline Interaction Flow Chart 
continues to track the spillet's center until time runs out at which time and the spillet is projected offshore as shown in Figure $A-2 b$ or in Figure $A-2 C$ if it has not already been projected offshore earlier in the time step.

At the end of the sequence for each spillet, ten percent of the ofl in that spillet is distributed among the shoreline segments crossed and the new spillet position is stored.

The algorithm is similar for the subsurface particles except that subsurface particles are not restricted by booms so this is not checked and the particle is deposited on shore when the first segment is hit. 


\section{Exomple a}

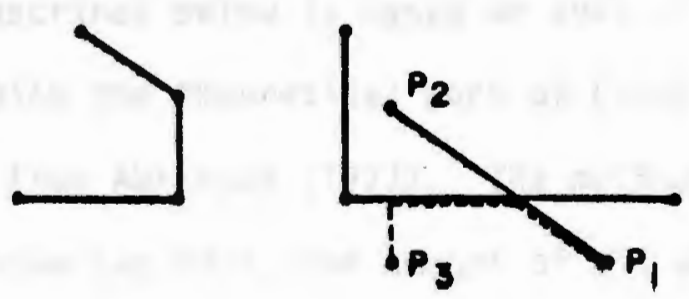

Example $b$

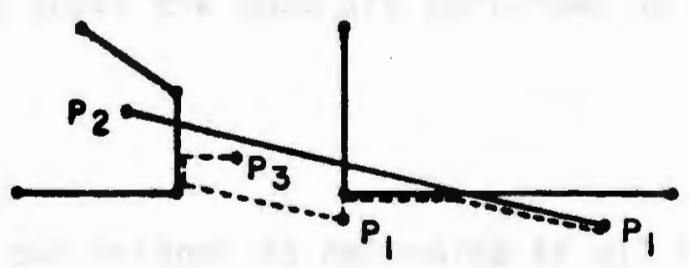

Example C

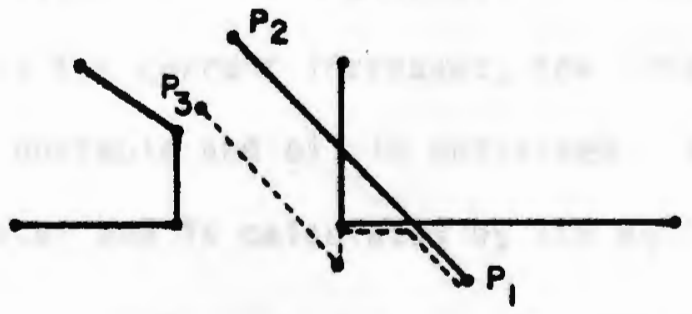

$P_{1}-P_{2}$ Spillet movement without shoraline present

-..- Spiliet movement with shoreline present

- Projection of spillet position of fshore

$P_{3} \quad$ Final spillet Position

Figure A-2 Simulated Spillet Movement 


\section{APPENDIX B}

\section{Boom Modeling}

The boom model described below is based on that of Swanson and Spaulding (1980) in which the theoretical work of Cross and Hoult (1971) Is combined with data from Abrahams (1977). The method calculates the amount of oil that a boom can hold, the amount of oil which escapes around the boom and the amount entrained into the water column. The flowchart for the routine is shown in Figure $B-1$. The calculations to determine the currents under the boom are performed in another subroutine and stored for use.

The routine uses two methods to determine if oil can be held by a boom. The first method is based on the critical Froude number. Figure B-2 shows the cross section of a boom with oil in it and current moving from left to right. As the current increases, the interface between the oil and water becomes unstable and oil is entrained. The Froude number is the critical parameter and is calculated by the equation:

$$
F^{F}=\frac{U}{g \Delta d}
$$

$$
\text { where } \begin{aligned}
U & =\text { current velocity } \\
g & =\text { gravitational constant } \\
\Delta & =1-\delta \text { where } \delta=\text { specific gravity of oil } \\
d & =\text { draft of boom }
\end{aligned}
$$

If this value is greater than the square root of two, then the water will essentially pull all of the oil below the boom. Otherwise, a calculation is performed in which the drag forces on the oil are compared with the 
BOOM LOSS

START

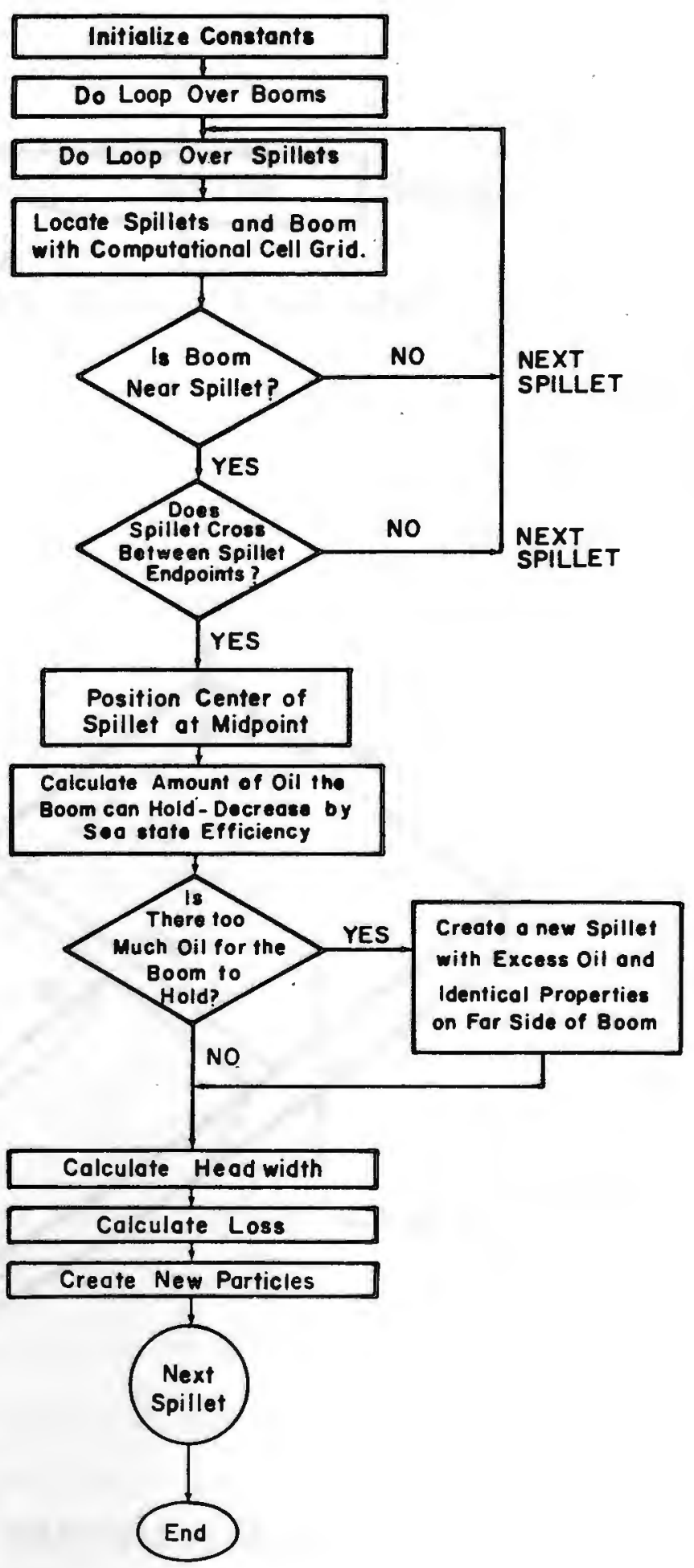




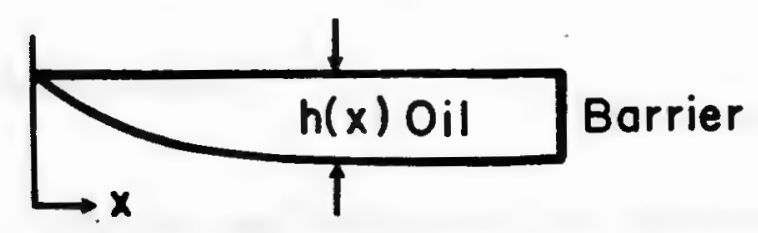

Figure B-1 Oil/Barrier Cross Section

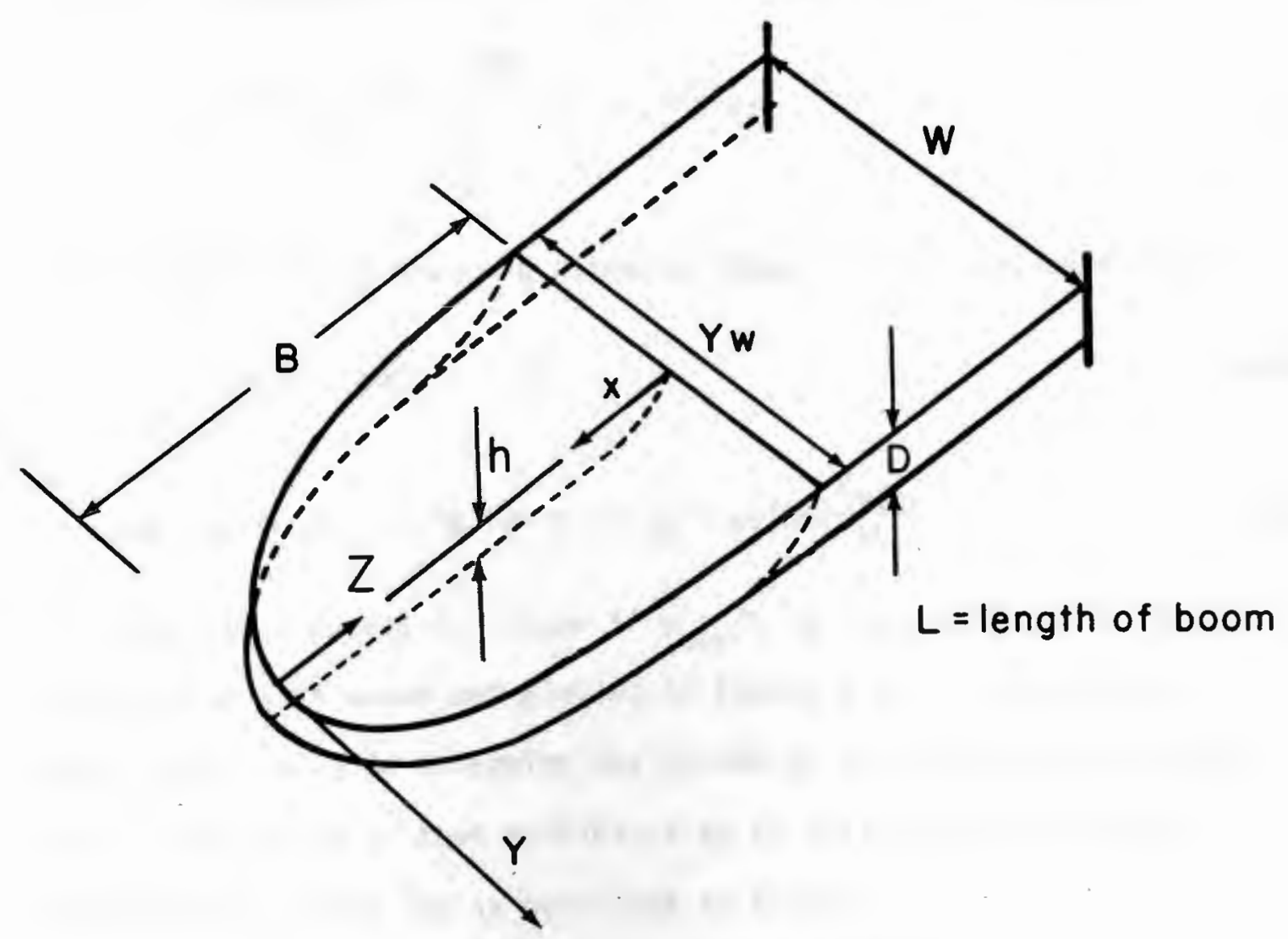

Figre B-2 Boom Definition Drawing 
buoyancy force. The result is an equation for the thickness of the oil:

$$
h^{2}=\frac{u^{2} c_{f} x}{g \Delta} \quad \text { where } c_{f}=.005 \text { for fuel oil }
$$

Refer to Figure B-3 for nomenc lature.

The volume of oil, is obtained by integrating the thickness of the 011 in $y$ and $z$ :

$$
\text { Volume }=\int_{\frac{y w}{2}}^{+\frac{y w}{2}} \int_{z}^{B} h(x) d z d y
$$

Since $h$ is independent of $y$, and $x=B-z$, equation B-2 becomes:

$$
v=\frac{U^{2} c_{f}}{g \Delta} \frac{1}{2} \int_{-\frac{y w}{2}}^{\frac{y w}{2}}(8-z)^{3 / 2} d z
$$

Since booms normally assume a catenary shape, a substitution for $z$ is:

$$
z=\lambda L\left[\cos H\left(\frac{y}{\lambda L}\right)+1\right]
$$

and the relationship for $\lambda$ is: $\frac{1}{2}=\lambda \operatorname{sinH}\left(\frac{y \max }{\lambda L}\right)$

This relationship is linear if $y_{\max } / L$ is less than .6 and an equation for $\lambda$ is shown and plotted in Figure $8-4$. Equation $8-3$ is solved numerically to determine the volume of oil which the boom can hold. This volume is then multiplied by an efficiency factor which depends on sea state and is described in Chapter III. 
If the volume of oil in the spillet(s) impinging on the boom is greater than the volume which the boom can hold, another spillet having the same oil propertles is created on the downstream side of the boom. For the oil which is in the boom, the spillet position is adjusted to the midpoint between the boom endpoints. The amount of ofl lost into the water column is then calculated using data from Abrahams (1977). Three linear curves have been approximated from Figure 8-5. Curve one is for sea states above 2. Curve two is low sea state with current velocities over 1.6 feet per $(.48 \mathrm{~m} / \mathrm{s})$ second and curve three is for currents be low 1.6 feet per second. Subsurface particles are then created and put into the water.

If the boom can hold all the oil impinging on it, no new spillets downstream are formed. 


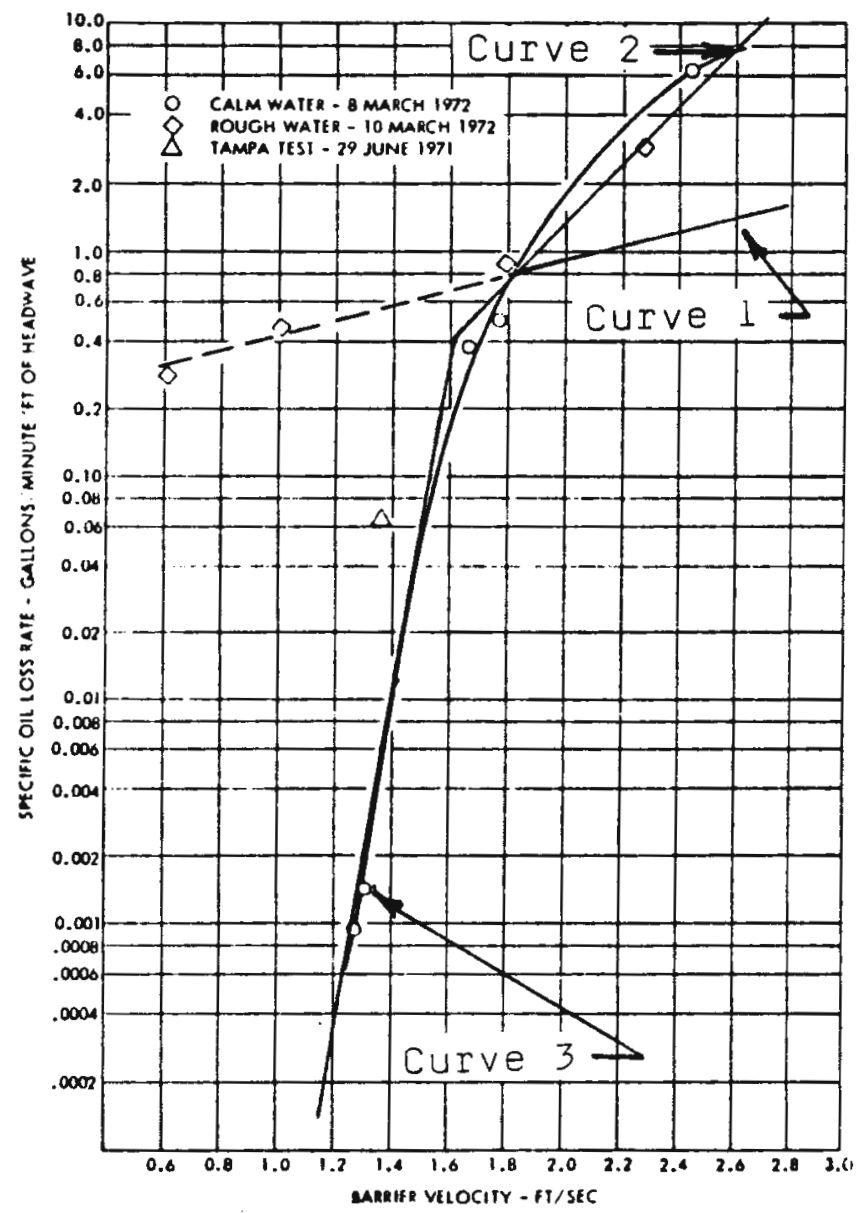

Figure $8-4$ Loss Rate (Abrahams 1977)

Specific Loss Rate vs Velocity - Steady State Operz- 
APPENDIX C

Block Is land Sound Runs

Besides being set up for Narragansett Bay, data was also accumulated for the Block Island Sound and Rhode Island Sound region. The run below simulates a theoretical 50 metric ton spill occurring at midnight, on october 7, 1977. Figures $c-7$ shows the grid of the study area and figure C-2 plots the wind which occurred over the first two days.

Maps of the spill (Figure $(-3$ ) indicate that the single spillet simulated moves almost directly west before moving to the coast and oiling several kilometers of beach. The entire shoreline between the two $X$ marks are oiled but the plotting algorithm places marks only at the coastline segment endpoints. The wind then shifts and moves the remaining oil out to sea. Figure $C-4$ displays the mass balance which shows that most of the oill is deposited on shore. The impact of the shoreline (Figure $C-5$ ) is seen to be the most important after about 34 hours when the subsurface concentration is lower than 50 parts per billion. The irregularities of the subsurface impact is again due to size of the grid element.

A simulated dispersant was deployed in a second run. A helicopter carrying a nominal load of 150 liters sprayed the spill approximately 3 $1 / 2$ hours after its start. The mass distribution (Figure $(-6)$ indicates that approximately two tons in addition to that of the first run were 


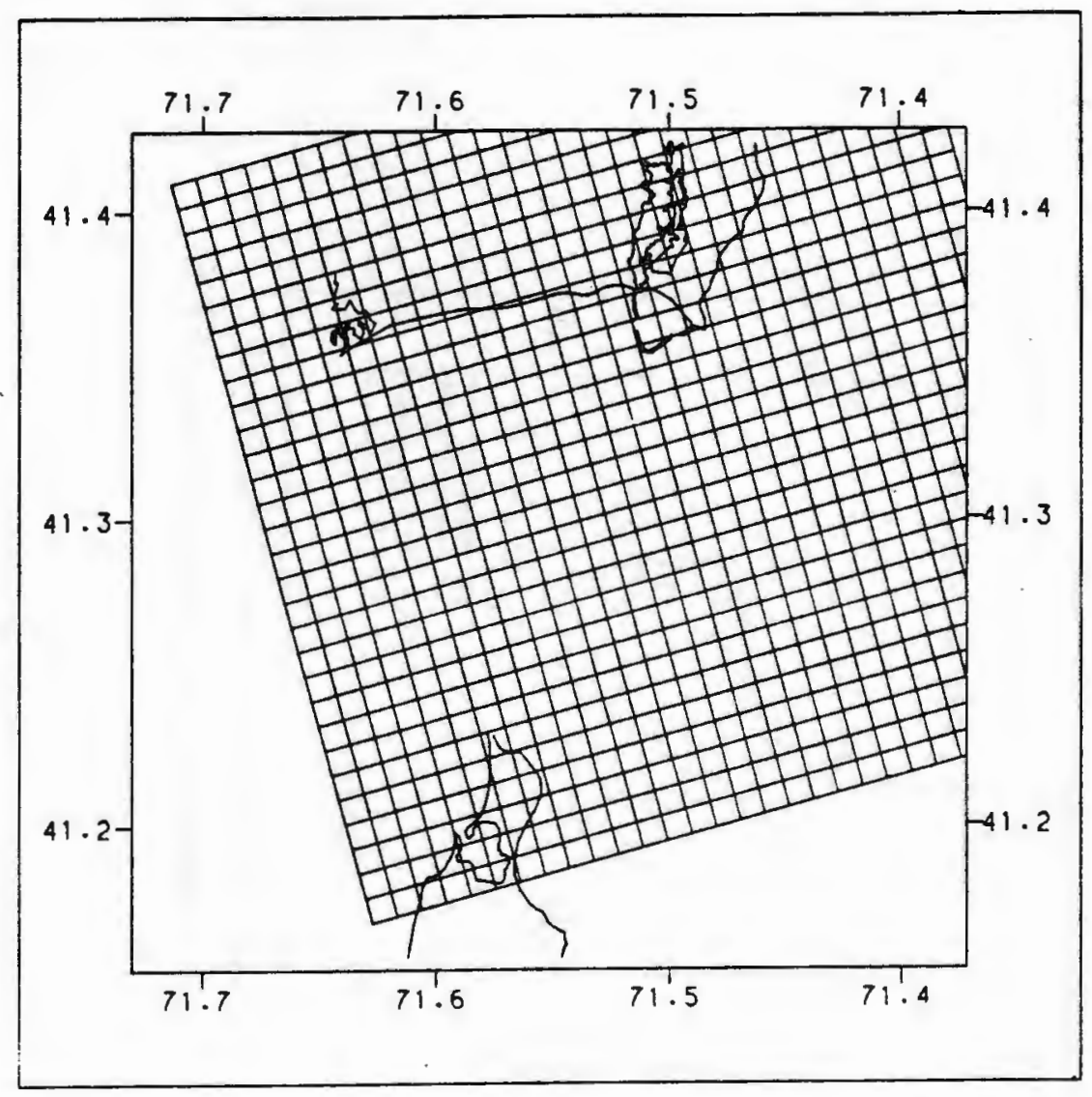

Figure C-l Block Island Sound Study Area

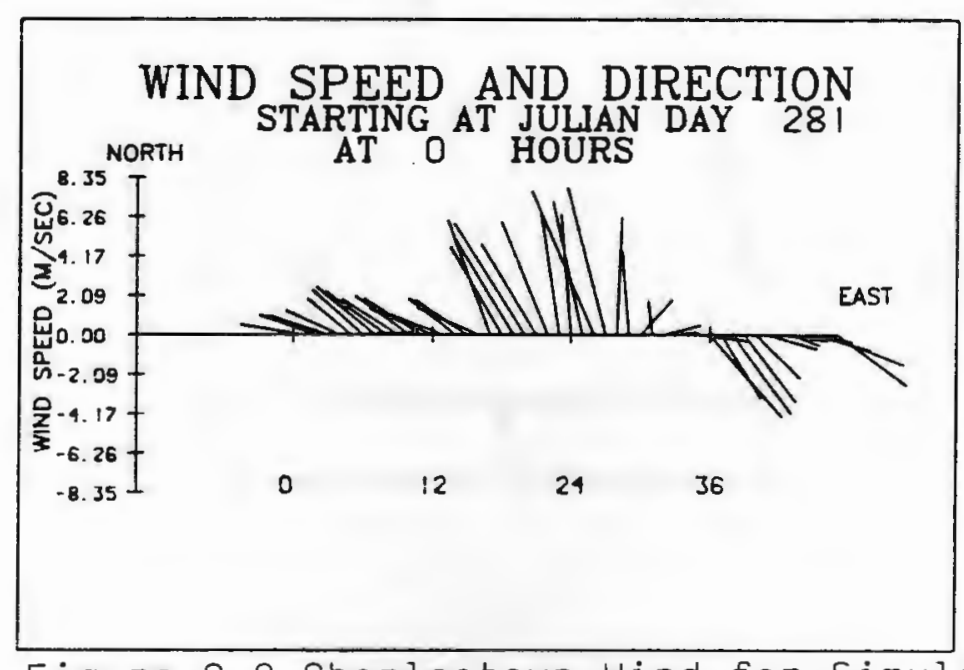

Figure C-2 Charlestown wind for Simulation 
6.0 HOURS AFTER START OF THE SPILL 11.9 HOURS AFTER START OF THE SPILL MAP OF SPILLETS AND SUBSURFACE

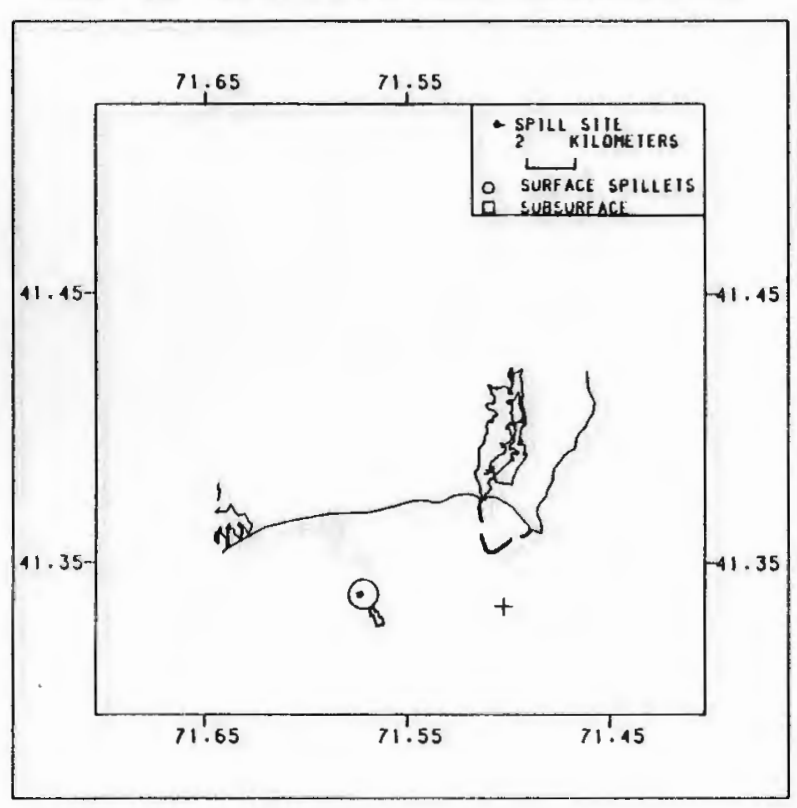

Figure $\mathrm{C}-3 \mathrm{a}$ MAP OF SPILLETS AND SUBSURFACE

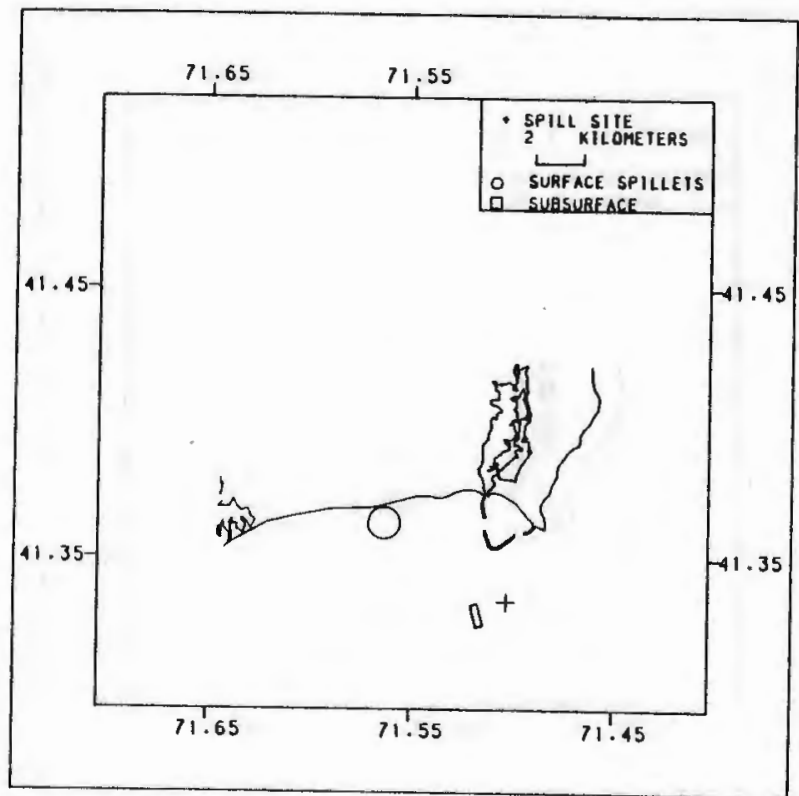

Figure $c-3 b$

Figure C-3 Oil Locations for Block Island Sound Simulation 
17.9 HOURS AFTER START OF THE SPILL MAP OF SPILLETS AND SUBSURFACE

$\stackrel{\text { 上 }}{\stackrel{2}{N}}$

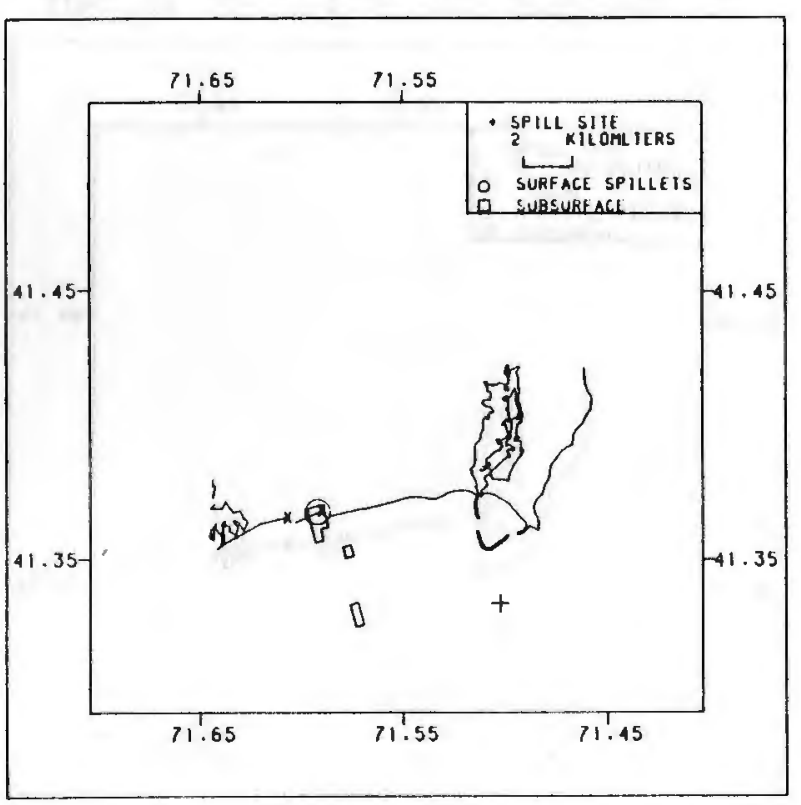

Figure $C-3 c$
23.8 HOURS AFTER START OF THE SPILL MAP OF SPILLETS AND SUBSURFACE

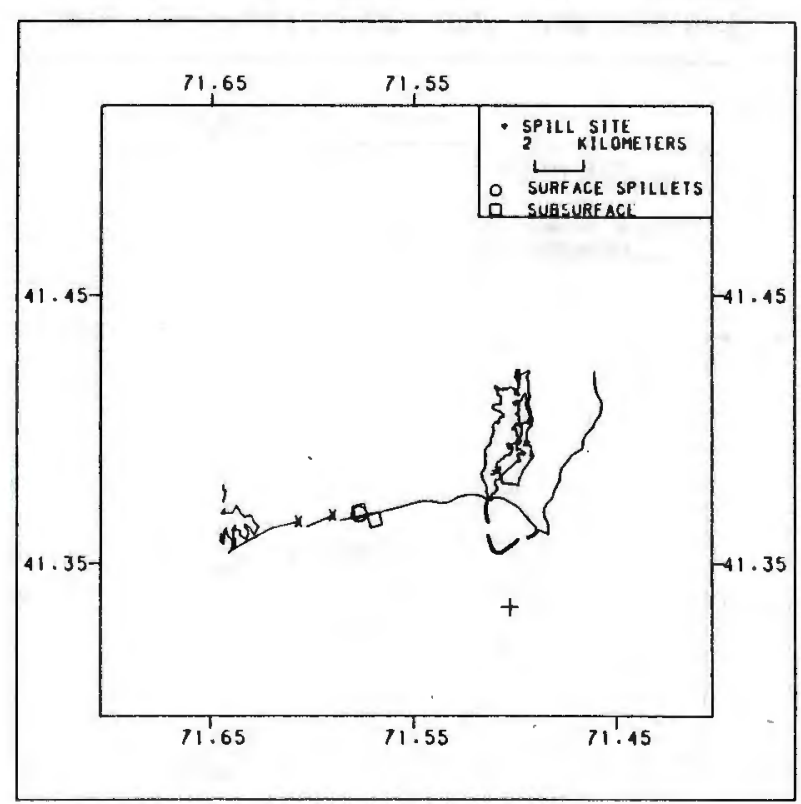

Figure $c-3 d$ 
29.8 HOURS AFTER START OF THE SPILL MAP OF SPILLETS AND SUBSURFACE

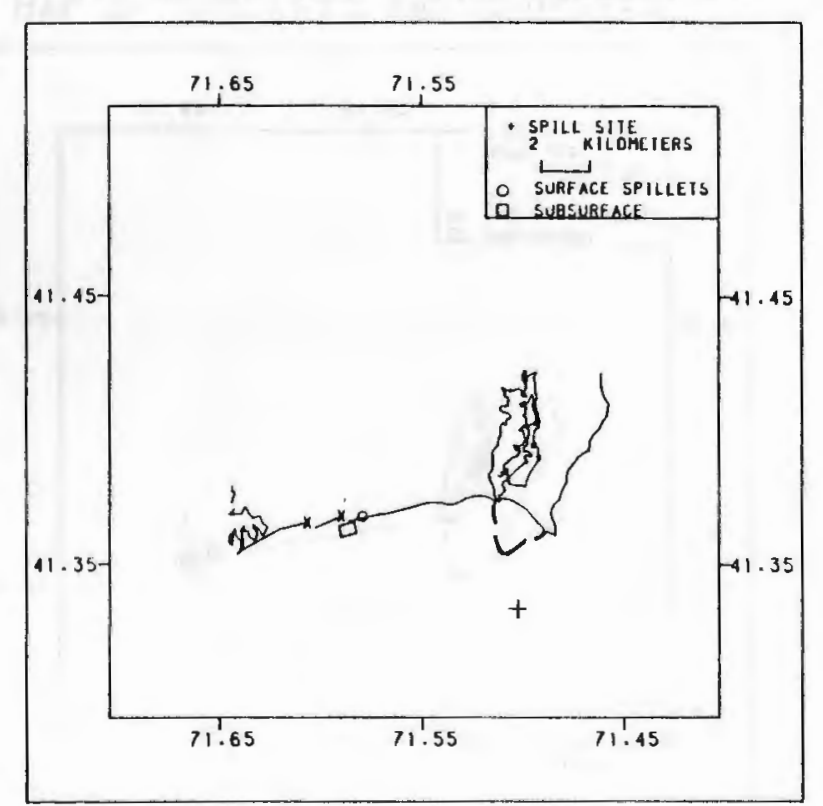

Figure $\mathrm{C}-3 \mathrm{e}$
35.8 HOURS AFTER START OF THE SPILL MAP OF SPILLETS AND SUBSURFACE

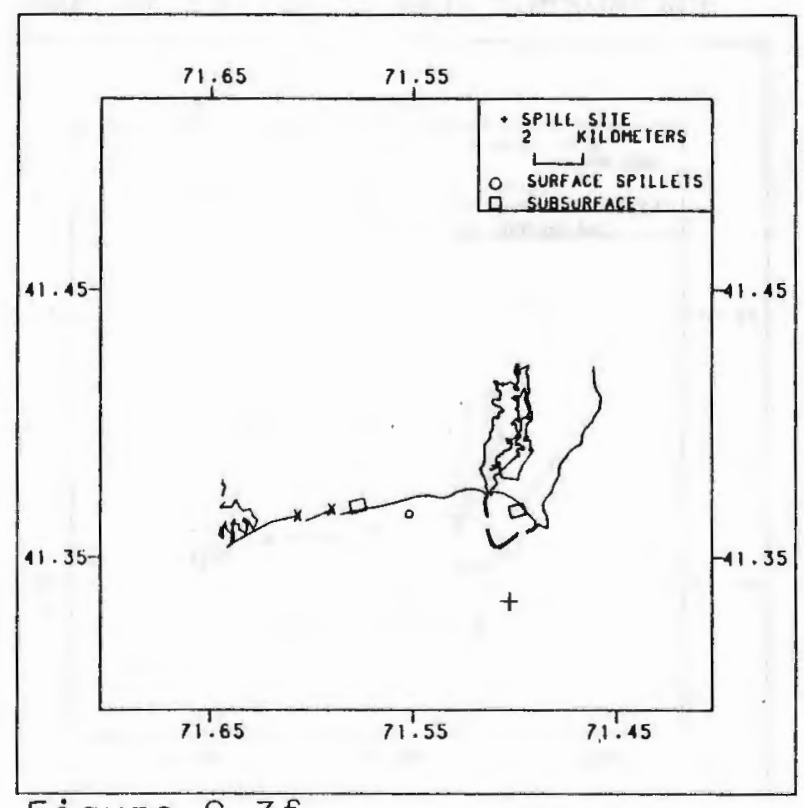

Figure $\mathrm{C}-3 \mathrm{f}$ 
41.7 HOURS AFTER START OF THE SPILL MAP OF SPILLETS AND SUBSURFACE

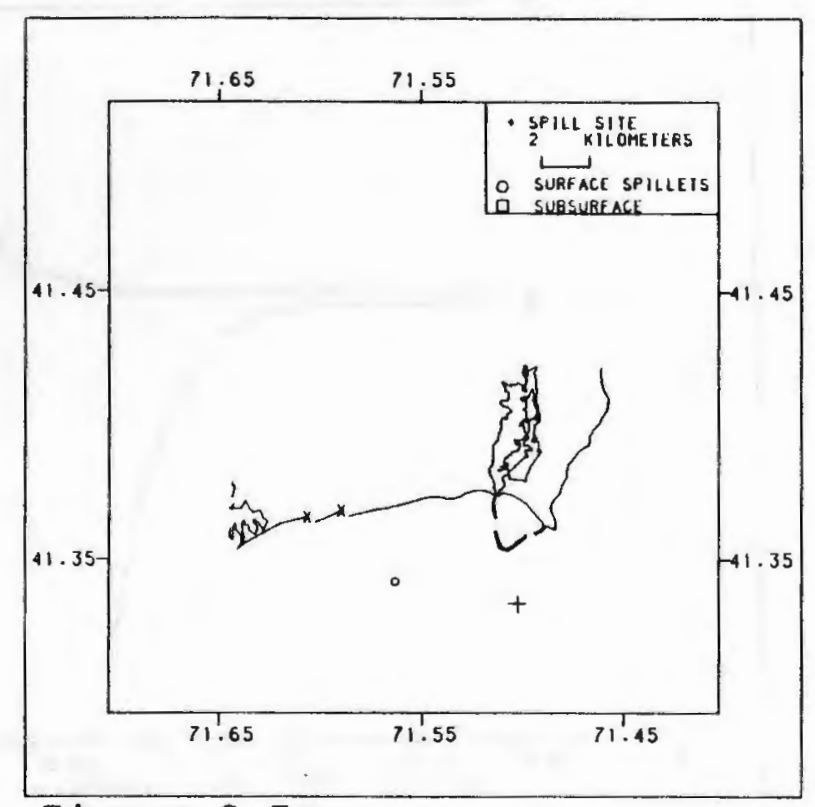

Figure $\mathrm{C}-3 \mathrm{~g}$
47.7 HOURS AFTER START OF THE SPILL MAP OF SPILLETS AND SUBSURFACE

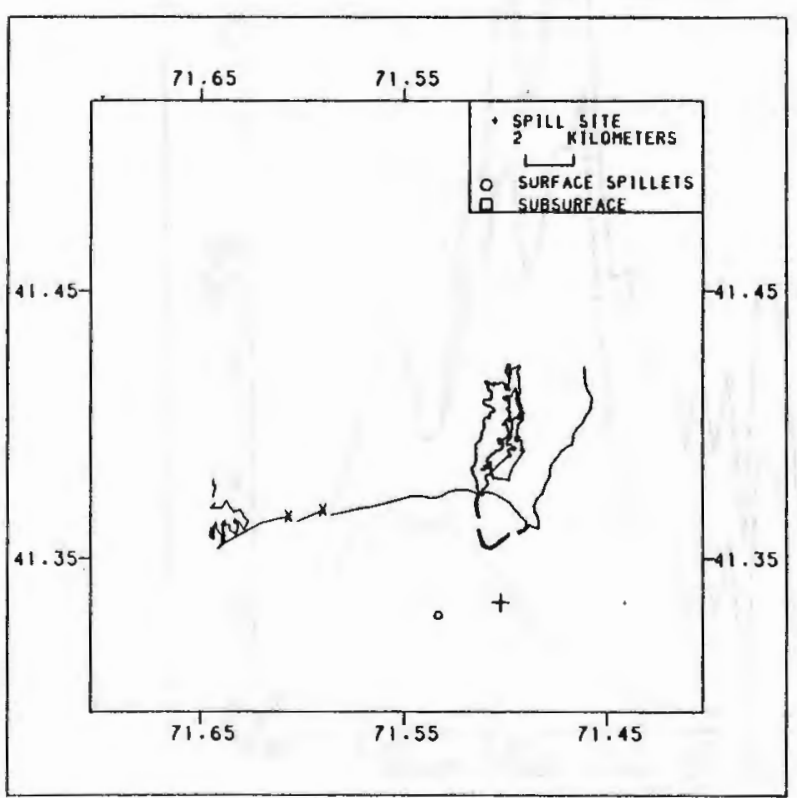

Figure $\mathrm{C}-3 \mathrm{~h}$ 


\section{MASS DISTRIBUTION}

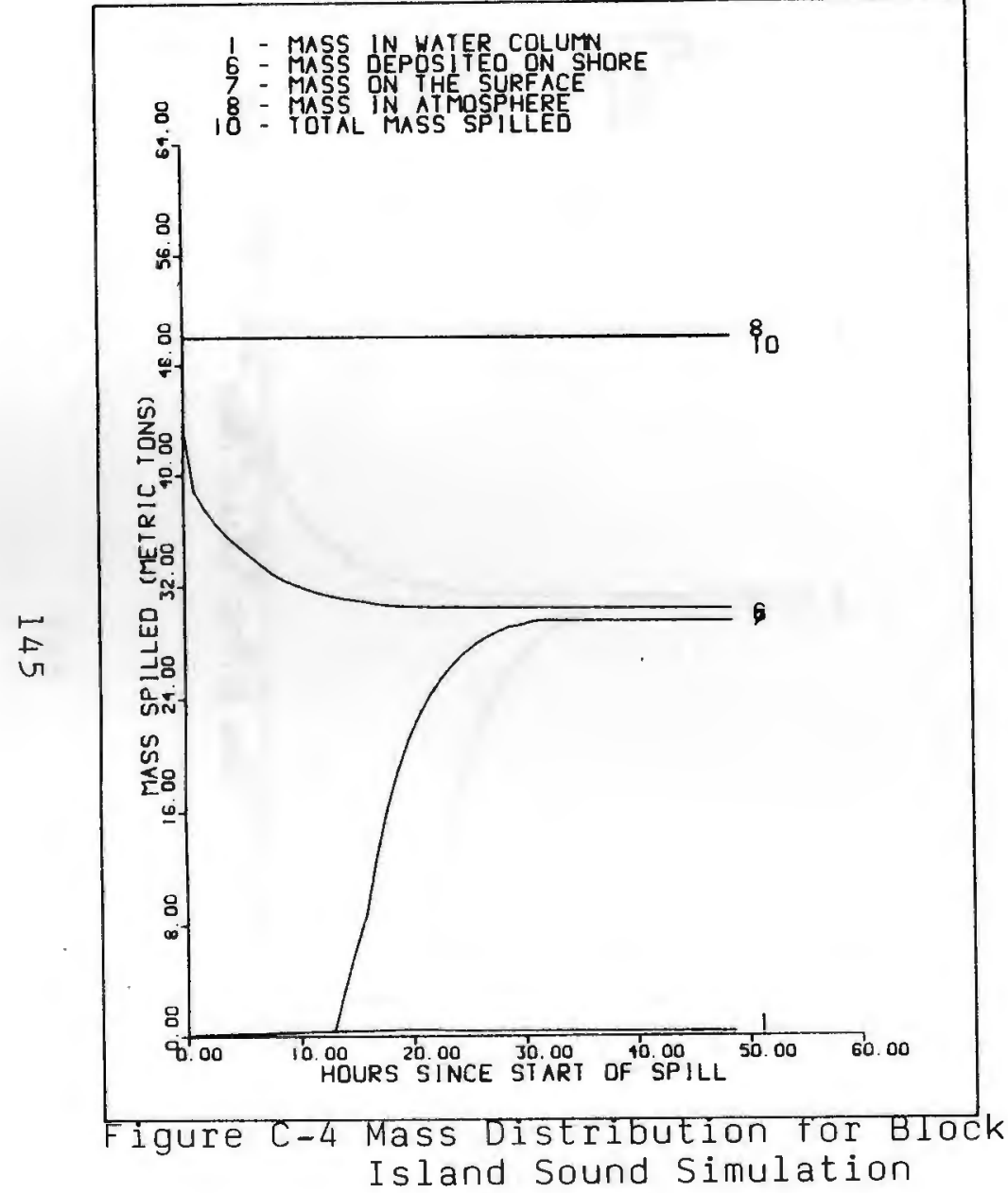

IMPACT OF SPILL

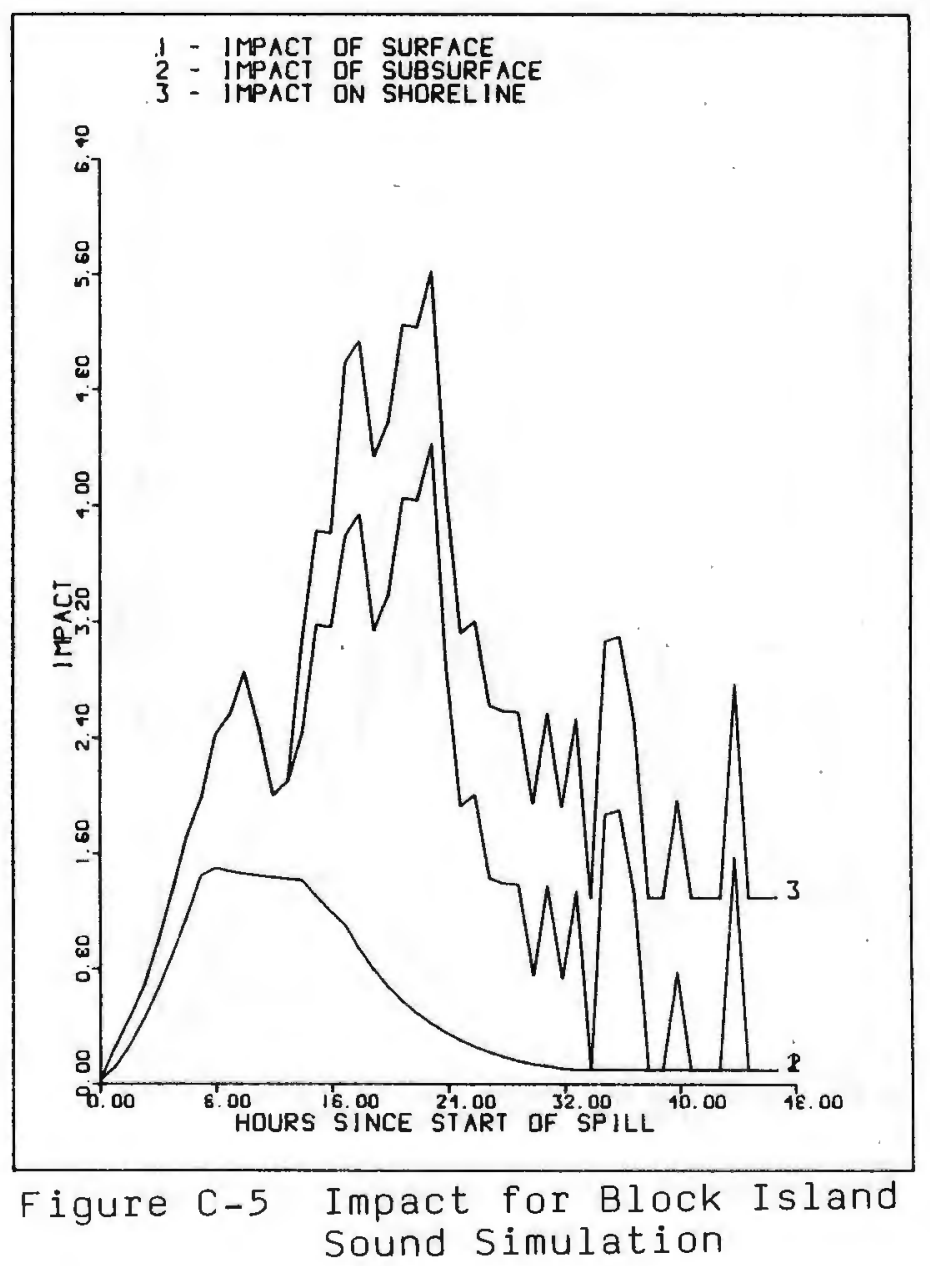




\section{MASS DISTRIBUTION}

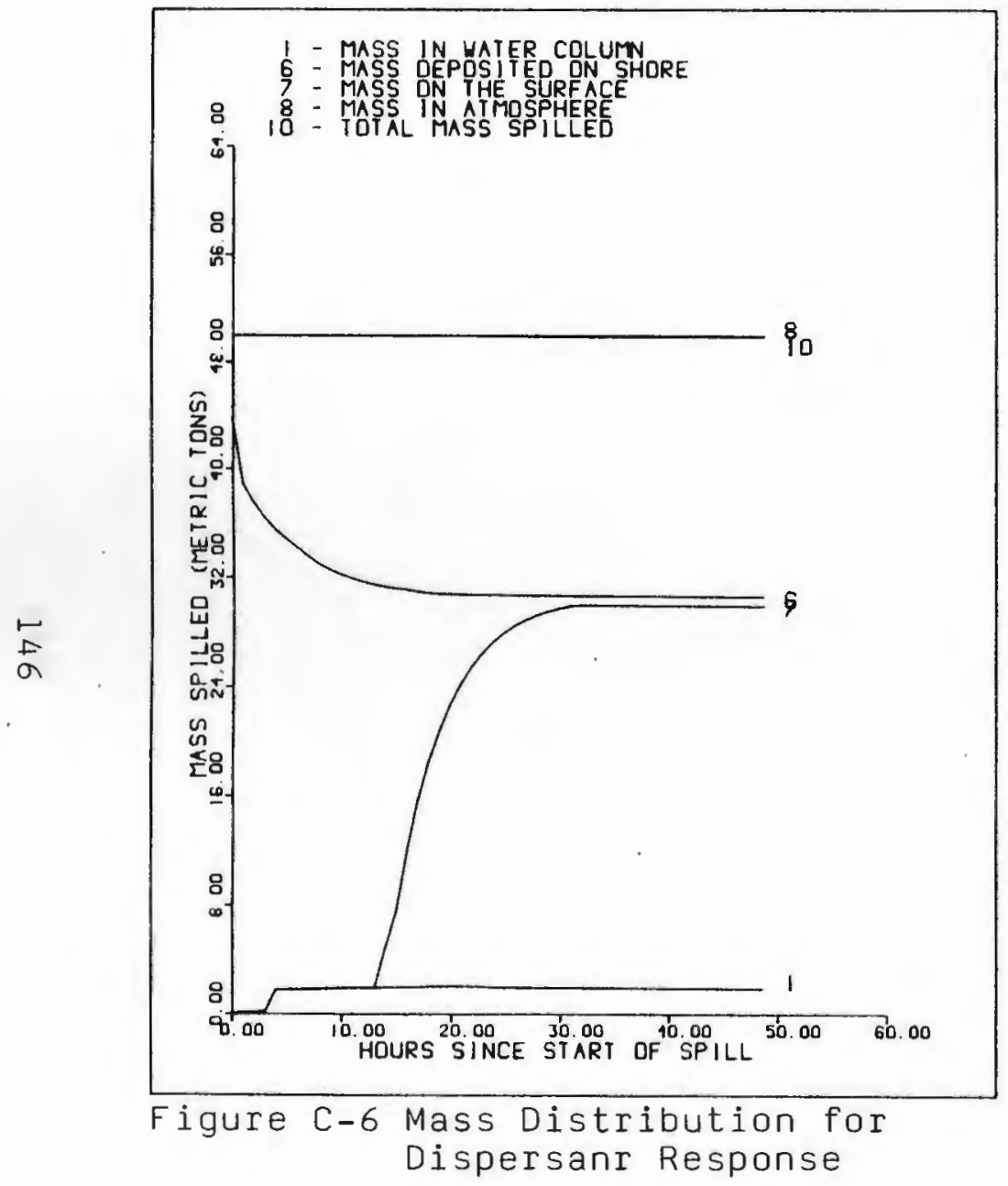

IMPACT OF SPILL

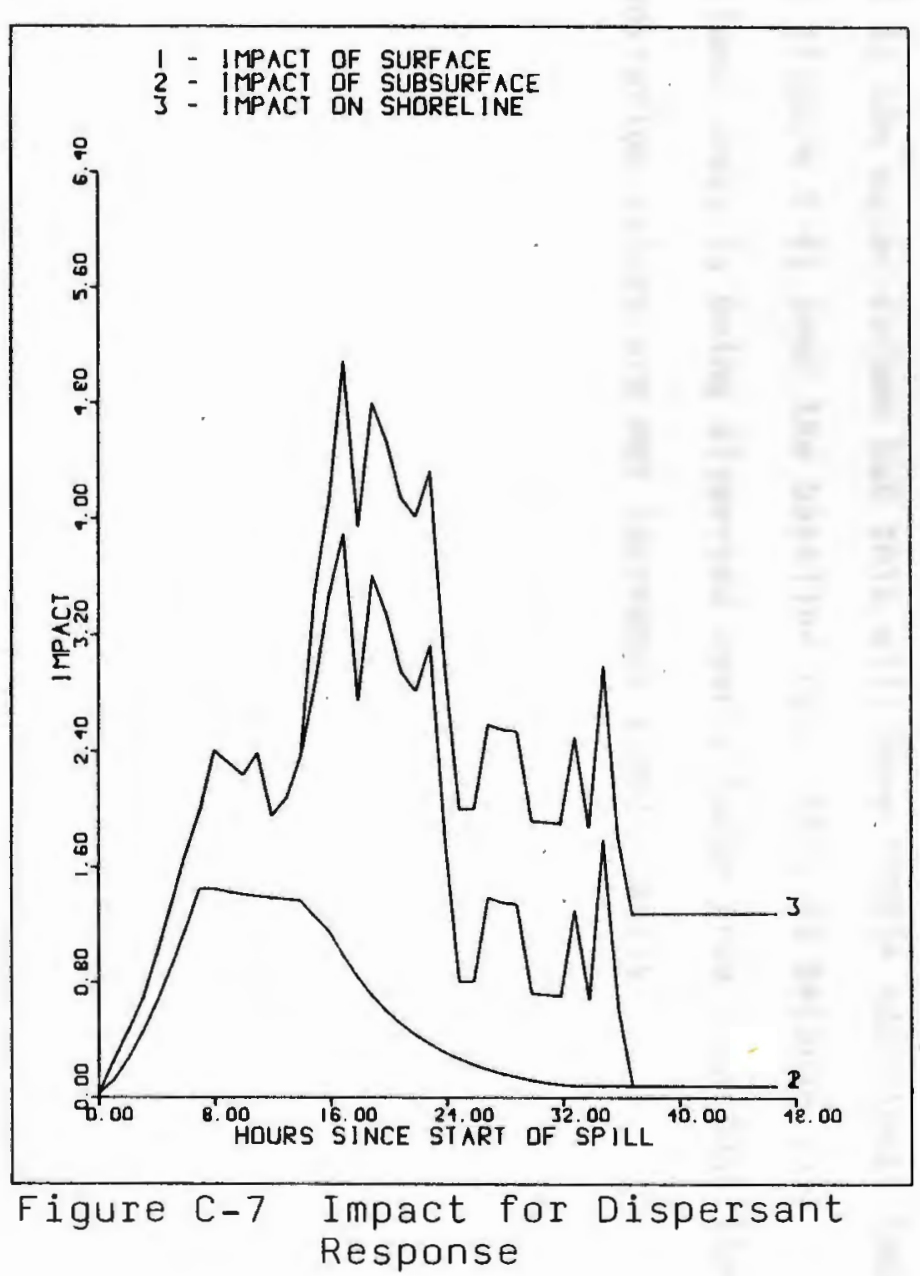


added to the water column but this will have little additional impact value (Figure $[-7$ ) over the baseline run. This is because this additional mass is being dispersed over a large area such that the concentration values are not increased significantly. 


\section{APPENDIX D}

Evaluator's Comments 


\section{US. Department of Transportation \\ United States \\ Coast Guard}

Mr. Curt Hansen

(University of $R I$ )

284A Pequotsepos Road

Mystic, CT 06355
U.S. Coast Guard

Marine Safety Office

Providence, RI 02903

09 Decenber 1985

Mr. Hansen:

This past February, IT. Sharon Christopherson of the National oceanic and Atrospheric Adninistration, and I attended a working demonstration of your oil spill training model.

During the demonstration I doserved your model detemine time delays in regard to oil spill trajectory forecasting, for specific weather and tide conditions, and calculate the effectiveness of containment and nemoval of oil from the water by use of various cleanup equipment incorporated within your system. I was also given the opportunity to operate your model and although I have no formal background with oomputers and only minimal experience as a computer operator. I believe your system oould be used effectively by personnel in the field given sufficient time and training for system familiarity.

Unfortunately, our work schecules did not provide sufficient time for other than a quick overview of your model's potential, However, speaking from past experience with pollution cleanup responses, I believe your model could become a useful tool in the field allowing more timely and oost efficient deteminations to be made of the types and amounts of equipment required during initial oil pollution contairment and cleanup responses.

I can appreciate the time and effort you must have expended on this project and would welocme a second opportunity to leam more and discuss further aspects of your model.

Sincerely,

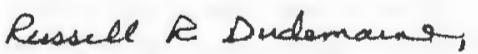

$B M I$

RUSSALL $R$, DUDEMAINE

Petty Officer, First Class

U. S. Coast Guard

(401) 528-5335 


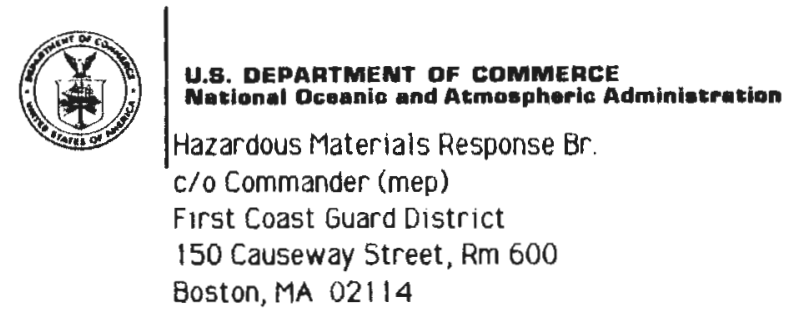

DATE: January 5, 1986

TO: Kurt Hansen

Dept. Ocean Engineering

University of Rhode Island

FROM: Sharon K.Chistophewars

SUEUECT: Demonstration of Narragansett Bay Oil Spill Computer Model with Respect to Oil Spill Response Training

Thank you for your demonstration last February of the Narragansett Bay o11 Spill Computer Model. As the NOAA Scientific Support Coordinator, I am involved in both oil spill response work and contingency planning for oil spills on the state and federal levels in the New England area. From your demonstration, I can see a number of applications of your model to both local response personnel training and contingency planning.

As a training tool, your model allows an individual to become familiar with the various factors of wind, currents, tides, and physical characteristics of oil which act together to determine slick movement. The determination of surface and water column oil concentrations and the weighted scoring of impacts on different shoreline types identifies the need to develop a protection strategy which will minimize the overall impact. I thought the additional capability of deploying response equipment and the inherent logistical problems, both in terms of time and money, associated witr, the different response options to be particularly useful in giving an individual insight into some of the operational constraints of a response.

In the area of contingency planning, I think your model could be helpful in addressing the question of the the most cost effective siting of response equipment based on worst case or historically typical spill scenarios. A second area where your model might be helpful is determining in what areas and under what conditions dispersants might be considered for

spill response. NOAA and the Coast Guard are currently doing a study of the transportation pattern of hazardous materials in warragansett Bay and adjacent coastal areas. On the basis of this study, we plan to develop site specific contingency plans for areas considered to be particularly "at risk". I would enjoy meeting with you again to discuss whether the Narragansett Bay Oil Spill Model might be useful in developing these plans 


\section{BIBLIOGRAPHY}

Abrahams, Cdr., R. N., and E. R. Miller Jr., 1977. "0il Spill Containment System Development and Testing Program," 1977 0il Spill Conference.

Allen, Tom E., 1982. "0il Spill Cleanup Equipment and Capability, ocS Georges Bank," Georges Bank - Hydrocarbon Exploration and Development, A Technological Conference, April 27-30, 1982, Nantucket Is land, Massachusetts.

Anderson, Eric L., 1983. "Hindcast Simulation of the Ixtoc I Gulf of Mexico Spill, Master's Thesis," University of Rhode Island.

Argo Merchant 0il Spil1, 1978. On-Scene Coordinators Report, U.S. Coast Guard.

Audunson, T., V. Dalen, J. P. Mathesen, J. Haldorsen and F. Krogh, 1980. "Slickforcast - A Simulation Program for $0 i l$ Spill Emergency Tracking and Long Term Contingency Planning, Report for the Continental Shelf," Petromar '80, Monaco.

Auguier, Antoine, and Jean Francois Bedin, 1982. "Initial Approach to a Cost-Benefit Analyses of Spimmer/Boom Systems to Coasted $0 i 1$ Pollution off the French Coasts," The cost of $0 i 1$ Spills, Organization for Economic Cooperation and Development: 87-104. 
Beach, R. L. et All., 1978. Investigation of Extreme Weather 0il Pollution Response Capabilities, Coast Guard Report No. CG-D-68-78, September, 1978.

Beachamp, Charles H. and Malcolm L. Spaulding, 1978. Tidal Circulation in Coastal Seas, University of Rhode Is land Reprint No. 110.

Beachamp, Charles H., 1979. "A Two Dimensional Vertically Averaged Numerical Model of Tidal Dynamics in the Southern New England Intracoastal System," Master's Thesis, University of Rhode Island.

Be11, Victor, 1981. "Protection Strategies for Vulnerable Coastal Features," 1981011 Spill conference: 501-507.

Bellantoni, J., J. Garlitz, R. Kodis, A. O'Brien Jr. and A. Passea, 1979. Deployment Requirements for the U.S. Coast Guard Pollution Response Equipment, Coast Guard Report No CG-D-14-79 I and II, February, 1979.

Birkeier, William A., and Robert A. Dalrymple, 1975. "Nearshore Water Circulation Induced by Wind and Waves, Journal of Waterways, Harbors and Coastal Engineering," ASCE: 1062-1081.

Blaikley, D. R., G. F. L. Dietzel, A. W. Glass and P. J. Vankleef, 1977. "Sliktrak - A Computer Simulation of Offshore 0il Spills, Cleanup, Effects and Associated Costs," 1977 0il Spill Conference: 45-52. 
Byroade, Jan, D., Ann M. Twedell and J. Peter LeBoff, 1981. Handbook for $0 i 1$ Spill Protection Cleanup Priorities, EPA Report No. 600/881-001 and 002 , February, 1981.

Coastal Resources Center, University of Rhode Island. State of Rhode Island 0il Spill Contingency Guide: Protection Strategies for Vulnerable Coastal Features.

Cochran, R. A, G. A. Manney and J. P. Fraser. "Computer Simulation of Off-shore Cleanup Operations," $19750 i 1$ Spill Conference: 293-300.

Collins, Barclay P., 1977. Residual Bottom Current in Eastern Rhode Island Sound Based on Drifter Results, Graduate School of Oceanography, University of Rhode Island, March, 1977.

Consortium on Spill Training (COST), 1974, Public Relations at the Spill Scene, Handbook, Canada. - 1976. Safety at the Spill Scene, Handbook, Canada.

Cormack, D., and P. G. Jeffery, 1977. "An 011 Pollution Control officer Training Course," 1977 0il Spill Conference: 69-72.

Cormack, D., 1983. Response to 0il and Chemical Marine Pollution, Applied Science Publishers, Ltd., New York. 
Cornillon, P. and M. Spaulding, 1978. An 0 il Spill Fates Model. Contract No. E(11-1) 4047. Department of Energy, Division of Environmental Control Technology.

M. L. Spaulding, and K. Hansen, "0il Spill Treatment Strategy Modeling for Georges Bank," Proceedings of the $19790 i 1$ Spill Conference, (EPA-API), March, 1979: 685-692.

and K. Hansen, 1980, "Sample Application of the 0il Spill Mode1: Georges Bank 0il Spill Simulations" in Assessment of Treated vs Untreated $0 i 1$ Spills. Final Report, December 1980, University of Rhode Island for Department of Energy Contract C00-4047-005.

Cross, Ralph H., and David P. Hoult, 1971. "0il Booms in Tidal Currents," Journal of Waterways, Harbors and Coastal Engineering Division, WW1, February, 1971: 25-34.

Davidson, L. W. and D. J. Lawrence, 1982. "Review of Existing 0 il Spill Trajectory Models," Canadian Technical Report of Hydrography and Ocean Sciences, 1, October, 1982, Bedford Institute of Oceanography, Nova Scotia.

Duerden, F. C., W. L. Pierce and R. G. Simmons, 1979. "Fireman and Emergency Personnel $0 i 1$ Spill Training Program," $19790 i 1$ Spill Conference: 209-211. 
Federal Register, 1975. Council on Environmental Quality, National 0il and Hazardous Substances Pollution Contingency Plan, Vol. 40, No. 28. February 10, 1975.

Foget, Carl R., Eric Schrier, Martin Cramer, and Robert Castle, 1979. Manual of Practice for Cleanup of Shorelines, Vol. I and II, Report No. EPA-600/7-79-187a and 187b, August, 1977.

Franklin, Harry L. 1977. "The Story of a Successful 0il Spill Cooperative: The Corpus Christi Area $0 i 1$ Spill Control Association," 1977011 Spill Conference: 65-68.

Fraser, J. P., 1979. "0il Spill Countermeasures - A Rational System for Selection and Sizing of Equipment," 1979011 Spill Conference: 253-255.

Garnett, M. J., 1978. "A Review of Recent Major 0il Spills Including the Amoco Cadiz," Spill Technology Newsletter, September-October, 1978: $17-24$.

Garry, B. J., 1981. "The Massachusetts 011 Spill Contingency Planning Program," 1981011 Spill Conference: 87-92.

Gilchrist, Ralph E., 1977. "The Spill Training and Education Program at Texas A. and I. - Corpus Christi," $19770 i 1$ Spill Conference: $135-136$. 
Gordon, Robert B., 1981. Personnel Communication. - 1982. Wind-driven Circulation in Narragansett Bay, Ph.D. Thesis, University of Rhode Is land, 1982.

Gundlach, Erich R., and Miles D. Hayes, 1978. "Vulnerability of Coastal Environments to $0 i 1$ Spill Impacts," Marine Technology Society Journal, Vol. 12, No. 4, 1978: 18-27.

Harrald, Cdr. John R., and Lt. Steve M. Conway, 1981. "The Use of Decision Support Aids in the Development of an Action Oriented Contingency Plan," 1981011 Spill Conference: 509-512.

Hess, Wilmont N., Editor, 1978. Amoco Cadiz 0il Spill, A Preliminary Scientific Report, NOAA EPA Special Report, April, 1978.

Holmes, P. D., 1977. "A Model for the Costing of $0 i l$ Spill clearance Operations At Sea," 1977 0il Spill Conference: 39-44.

Huang, James C., and Francis C. Monastero, 1982. Review of the State-of-the-Art of 011 Spill Simulation Models, Final Report, Submitted to American Petroleum Institute, Raytheon Ocean Systems Company, June, 1982.

Hubbard, J. F., and T. E. Allen, 1979. "Clean Atlantic Associates: An

Oil Spill Cleanup Cooperative for the Atlantic Offshore Area," 1979 0il Spill Conference: 229-236. 
Hum, Suling, 1977. "The Development and Use of Resource Sensitivity Maps for 011 Spill Countermeasures," 1977011 Spill Conference.

Hunter, David, 1975. "Development of a Three Dimensional Numerical Water Quality Model for Estuary and Continental Shelf Applications," Master's Thesis, University of Rhode Island.

Hunter, Dr. J. R. 1980. "An Interactive Model of 0 il Slick Motion," Oceanology 80, Morraco, 1980.

Imbrie, Lt. Cdr. Robert J. and Kirk R. Karman, 1979. "Computer Searching for Pollution Cleanup Equipment," 1979011 Spill Conference: 257-260.

Impact and Cleanup of 011 Spills on Canadian Shorelines: A Summary, 1978. Training Manual, Department of the Environment, October, 1978.

Jordon, Randolph, E., and James R. Payne, 1980. Fate and Weathering of Petroleum Spills in the Marine Environment, Ann Arbor Science Publishers, Inc., Ann Arbor, Michigan, 1980.

Kangeter, Lt. Edward B., 1977. "Hiatus - An On-scene Coordinator Role Playing Exercise," 1977011 Spill Conference: 141-143.

Kay, Garnet H., 1977. "Canadian Approach to 011 Spill Training," 1977 0il Spill Conference: $137-138$. 
Kolpack, R. L., N. B. Plutchak, and R. W. Stearns, 1977. Fate of 0 il in a Water Environment - Phase II. A Dynamic Model of the Mass Balance for Released 0il. University of Southern California, API

Publication 4313, American Petroleum Institute, Washington, D.C. 20037.

Kondratowicy, Ludwik J., and Harilaos N. Psaraftis, 1980. The 0il Spill Incidence and Simulation Model: Description and Users Manual, MIT Seasrant Report No. 80-17, October 1980.

Lichte, H. W., 1979. "Skimming Barrier Performanc Evaluation: Offshore Version and Harbor Version," $19790 i 1$ Spill Conference: 489-492.

Lindstedt-Siva, June, 1977. "0il Spill Response Planning for Biological Sensitive Areas," $19770 i 1$ Spill Conference: 111-114.

Lissauer, Ivan and Donald L. Murphy, 1979. "0il Spill Forcasting - Where is it Going , "1979 0il Spill Conference: 649-652.

Little, Arthur D. Corp., 1969. Combatting Pollution Created by 011 Spills - Volume One: Methods, June 30, 1969, Coast Guard Report.

Lundblon, Gordon P., "Logistic Planning for 0il Spill Chemical Use," 1979 0 il Spill Conference: $453-458$.

MacKay, Donald, 1978. "0il Spill Modeling: Problems and Purposes", Spill Technology Newsletter, July-August, 1978. 
Malins, Donald C., 1977. Effects of Petroleum on Arctic and Sub-Arctic Marine Environments and Organisms, Volume I, Nature and Fate of Petroleum, Academic Press, New York.

Marcolini, R. A., J. L. O'Brien, C. B. Doherty and M. H. Simpson, 1980. "Operating Experience with Coast Guard Pollution Equipment, IXTOC I", Marine Technology Society, $16^{\text {th }}$ Annual Conference, October 1980, Washington, D.C.: 137-141.

Marcus, Capt, E., 1977. "A Bad Day at Bunker Point," 1977011 Spill Conference: $139-140$.

McAuliffe, Clayton, Brian L. Stedman, William R. Leek, Donald E. Fitzgerald, James P. Ray and Charles D. Barker, 1981. "The 1979 Southern California Despersant Treated Research Spills," $19810 i 1$ Spill Conference: 269-281.

Meade, Norman F., 1982. "The Amoco Cadiz 011 Spill: An Analysis of Emergency Response, Cleanup and Environmental Rehabilitation Costs," OECD, 1982: 130-147.

Michel, J., et All., 1981. "Distribution and Quantification of Bottom

$0 i 1$ Incorporated within the Bays of Lannion and Morlaix. Four and One-half Months after the Amoco Cadiz 0il Spill," report for NOAA, Contract No. NA79RA00008, Research Planning Institute, Columbia, South Carolina. 
Model Predicted Tidal Current Charts, 1979. Long Is land Sound to Buzzards Bay, URI Marine Bulletin, No. 30, NOAA/Sea Grant.

National Conventioneer, 1979. Reference Book, $19790 i 1$ Spill Conference, New Technologies and Equipment Book.

No11, Christopher, and Malcolm Spaulding, 1977. URI - EROA 0il Spill Mode1, Quonset Point Spil1, Department of Ocean Engineering, University of Rhode Is land, October, 1977.

Nyhart, J. D., Harilaas N. Psaraftes and Walter S. Laird, 1981. "The Legal Environmental Component of an 0il Spill Cleanup Model," 1981 011 Spill Conference: $695-700$.

O'Brien, Lt. Cdr. J. L., 1981. "National Strike Force Response IXTOC I Blowout - Bay of Campeche," 19810 0il Spill Conference: 125-130.

0il Spill clean-up: An Economic and Regulatory Model, Opportunity Brief No. 25, July 1, 1981, Marine Industry Advisory Services, MIT Sea Grant Program, Cambridge, Massachusetts.

0lsen, Stephan, Donald D. Rubadue and Virginia Lee, 1980. An Interpretive Atlas of Narragansett Bay, Coastal Resources Center, University of Rhode Island Bulletin No. 40. 
Omohundro, John T., 1980a. $0 i 1$ Spills: A Public Officials Handbook, Information Bulletin 166, N.Y. State College of Agriculture and Life Sciences.

- 1980b. 011 Spills: A Coastal Residents Handbook, Information Bulletin 164, N.Y. State College of Agriculture and Life Sciences.

Owens, E. H., and C. R. Foset, 1982. "A Small River 0il Spill: A Long Step Back for Cleanup Technology, Spill Technology News letter," January-February 1982: 7-10.

Pavish, Danny L., 1977. Development and Application of a Three Dimensional Numerical Model for Predictions Pollutant and Sediment Transport Using An Eulerian-Lagrangian Marker Partical, Master's Thesis, University of Rhode Is land.

Payne, J. Larry, et al., 1981. "Texas A and M 0 il Spill Training Activities - A Sixth Year Perspective," 1981011 Spill Conference: $93-96$.

Pennant, LI/TK, 1973. Major 0il Spill, On-Scene Coordinators Report, Apri1 9. 1973.

Poley, Johannes, Ph., 1979. "Selective $0 i l$ Spill Combat Planning for Offshore Exploration and Production Operations in the North Sea," $19790 i 1$ Spill Conference: $641-647$. 
Premack, Joel, 1975. An 0il Spill Contingency Plan for the Rhode Island Estuary, Master's Thesis, University of Rhode Island, Parts I and II, 1975 .

Rappaport, Allen, et al., 1981. "The Media and 011 Spills: Does the Press Influence Damage Perceptions," 1981 0il Spill Conference: $707-712$.

Raytheon Ocean Systems Company, 1981. Reveiw of the State of the Art of 0il Spill Simulation Models, Phase I Report, American Petroleum Institute, February, 1981.

Reed, M. and M. L. Spaulding, 1979. An 0il Spill-Fishery Interaction Mode 1: Comparison of Treated and Untreated Spill Impacts. Proceedings of 1979011 Spill Conference, EPA-API, L. A.: 63-73.

- 1980. An 0il Spill Fishery Interaction Model - Development and Applications, Ph.D. Thesis, Department of Ocean Engineering, University of Rhode Island, Kingston, Rhode Island. - M. L. Spaulding, and P. Cornillon, 1981. A Fishery-0il Spill Interaction Mode 1: Simulated Consequences of a Blowout, Proceedings of MATO Symposium on Applied Operations Research in Fishing, 1981. Plenum Press, New York: 99-114. and Malcolm Spaulding, 1982. "A Computer Model System for Marine Pollutant Impact Assessment: Potential for Coastal State Use, Oceans 1982," Boston, Massachusetts: 1156-1163. 
Shepard, F. P., and D. L. Inman, 1950. "Nearshore Circulation Related to Bottom Topography and Wave Refraction," Trans. Am. Geophy. Uncon, 31. No. 4: 555-565.

Schiff, D., 1980. "011 Spill Cleanup Can be Effective and Self-Supporting," Spill Technology News letter, September-October, 1980: $140-146$.

Schulze, R. H., 1981. "A Cost Effectiveness Approach to 0il Spill Response," 1981011 Spill Conference: 495-500.

Schwartz, Sal H., 1979. "Performance Tests of Four Selected 0il Spill Skimmers," 1979011 Spill Conference: 493-496.

Shonting, David H., 1969. "Rhode Is land Sound Square Kilometer Study 1967: Flare Patterns and Kinetic Distribution," Jour. of Geophy. Res., Vol. 73, No. 13, June 20, 1969: 3386-3395.

Shore Protection Manual, 1975. 2nd ed., U.S. Army Coatal Engineering Research Center, Fort Belvoir, Virginia.

Sittig, Marshall, 0 il Prevention and Removal Handbook, Noyes Data Corporation, Park Ridge, N.J., 1974. 
Snooks, John H., and John P. Jacobson, 1979. "Currents and Residual Drift Block Is land Sound During the Period February through December 1977". Yankee Atomic Electric Company. Environmental Sciences Group, Westborough, Massachusetts, March, 1979.

Spaulding, Malcolm, and Craig Swanson, 1976. Tides and Tidal Currents of Narragansett Bay, URI Marine Technical Report No. 35.

- 1976. "Numerical Modeling of Pollutant Transport Using a Lagrangian Marker Particle Technique," NASA Technical Memorandum, NASA TMX-73939, August 1976.

Stolzenbach, Keith, O. S. Madsen, E. E. Adams, A. M. Pollack, C. K. Cooper 1977. A Review and Evaluation of Basic Techniques for Predicting the Behavior of Surface 0il Slicks, MIT Report No. 227, February, 1977.

Surface Weather Records, Green Airport Weather Bureau Station, National Climatic Center, Ashewelle, North Carolina.

Swanson, Craig, and Dr. Malcolm L. Spaulding, 1980. "A Model for the Dispersion of $0 i 1$ in the Wake of $0 i 1$ Containment Barriers," June, 1980 (unpublished).

Tamano, 1972. Major 0il Spill, On-scene Coordinates Report, July 22, 1972. 
Thomas, John H., "A Theory of Steady Wind Driven Currents in Shallow Water with Variable Eddy Viscosity," Journal of Physical Oceanography, Vol. 5, January, 1975: 136-142.

Tide Tables for 1977-1978, U.S. Coast and Geodetic Survey.

Tibbetts, A. M., "Training a Cleanup Response Team," $19750 i 1$ Spill Conference: $59-63$.

Torgrimson, Gary M, "A Comprehensive Model for Spill Simulation," 1981 $0 i 1$ Spill Conference: $423-428$.

Towle, USNS, 0il Pollution Incident, On-Scene Coordinators Report, July $14-28,1971$.

U.S. Coast Guard, 1972. Oil Pollution Investigation and Control School, November, On-Scene Coordinators.

- 1978. Commandant Instruction 16465.10, March 13, 1978,

Subject: Contingency Planning for Pollution Incidents.

. 1979. Commandant Instruction M16466.2, November, 1979,

Subject: 0il Pollution Response Planning Guide for Extreme Weather.

. 1981. COMDTINST M16450.20. "Polluting Incidents in and Around U.S. Waters," Calendar Years 1980 and 1981. 
Wang, M., W. C. Yang, and C. P. Huang, 1976, Modeling of 0il Evaporation in an Aqueous Environment. Ocean Engineering Report No. 7 , Department of Civil Engineering, University of Delaware.

White, J. C., J. A. Nichols and M. J. Garnett, 1979. "Ten-Year Overview of $0 i 1$ Spill Cleanup At Sea," $19790 i 1$ Spill Conference: 247-251.

[Wilson, Dr. Mason,] ed. 1980. Computer Manual. URI 0il Spill Model Appendix 5, Assessment of Treated vs Untreated 0il Spills, Final Report, December 1980, University of Rhode Island for Department of Energy Contract c00-4047-005.

Winant, Clinton, D., "Coastal Circulation and Wind Induced Currents," Review of Fluid Mechanics, Vol. 12, 1980: 271-301.

Wu, Jin, 1980. "Wind-Stress Coefficients over Sea Surface Near Neutral Conditions - A Revisit," Journal of Physical Oceanography, Vol. 10, May, 1980: 727-740.

Zimlicki-Owens, L. M., 1979. "0il Spill Training Workshops for Canada's Coasts," Spill Technology News letter, September-October, 1979: 301-303. 